\title{
Streamflow Characteristics of Mountain Streams in Western Montana
}

United States Geological Survey Water-Supply Paper 2260

Prepared in cooperation with the Montana Department of Natural Resources and Conservation

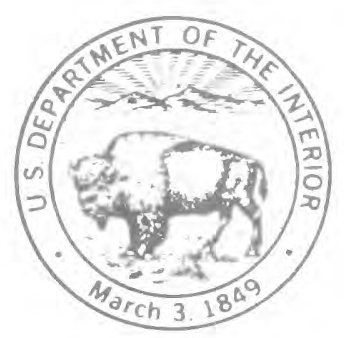




\section{Streamflow Characteristics of Mountain Streams in Western Montana}

BY CHARLES PARRETT and J. A. HULL

Prepared in cooperation with the Montana Department of Natural Resources and Conservation

U.S. GEOLOGICAL SURVEY WATER-SUPPLY PAPER 2260 


\title{
DEPARTMENT OF THE INTERIOR WILLIAM P. CLARK, Secretary
}

\author{
U.S. GEOLOGICAL SURVEY \\ Dallas L. Peck, Director
}

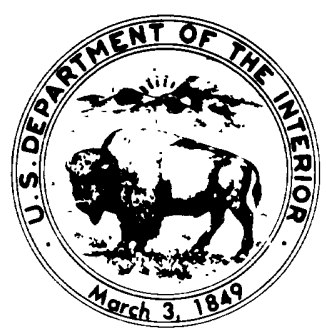

UNITED STATES GOVERNMENT PRINTING OFFICE: 1985

For sale by Distribution Branch

Text Products Section

U.S. Geological Survey

604 South Pickett Street

Alexandria, Virginia 22304

Library of Congress Cataloging in Publication Data

Parrett, Charles.

Streamflow characteristics of mountain streams in western Montana.

(U.S. Geological Survey water-supply paper ; 2260)

Bibliography: $\mathrm{p}$.

Supt. of Docs. no.: I 19.13:2260

1. Stream measurements-Montana. I. Hull, J. A. II. Montana.

Dept. of Natural Resources and Conservation. III. Title.

IV. Series.

GB1225.M9P37

$1985 \quad 551.48^{\prime} 3^{\prime} 09786$

$84-600222$ 


\title{
CONTENTS
}

\author{
Abstract 1 \\ Introduction 1 \\ Description of the area 2 \\ Streamflow measuring sites and gaging data 2 \\ Methods of analysis $\mathbf{2}$ \\ Estimating streamflow characteristics from discharge measurements 4 \\ Extending streamflow records to a common base period 4 \\ Estimating long-term streamflow characteristics $\mathbf{6}$ \\ Appraisal of accuracy 9 \\ Variations in mean annual runoff $\mathbf{1 0}$ \\ Equations for estimating streamflow characteristics 14 \\ Mean annual discharge 14 \\ Flows of various exceedance percentages 16 \\ Prediction accuracy and limitations 18 \\ Summary 19 \\ References cited $\mathbf{2 0}$ \\ Metric conversion factors \\ 58
}

\section{FIGURES}

1. Map showing location of streamflow-measurement sites and gaging stations $\mathbf{3}$

2-6. Graphs showing:

2. Concurrent discharges on Camp Creek and Flower Creek 5

3. Estimated flow-duration curve for Soup Creek above Soup Creek

Campground 6

4. Regression equations relating long-term mean annual discharge to one annual mean discharge 7

5. Relationship of regression coefficient to exceedance percentage $\mathbf{8}$

6. Range of mean monthly discharges at gaging stations 9

7-9. Graphs showing estimated flow-duration curve for:

7. Flower Creek near Libby 9

8. Bear Creek near Victor 10

9. Swan River near Condon 10

10-12. Maps showing mean annual runoff in the:

10. Kootenai River area $\mathbf{1 1}$

11. Bitterroot River area $\mathbf{1 2}$

12. Swan River area 13

13. Map showing region boundaries $\mathbf{1 5}$

14, 15. Graphs showing dimensionless flow-duration curves for:
14. Region 117
15. Region 218 
1. Streamflow measurements and site descriptions 23

2. Annual mean discharge computation for Camp Creek (site 18) 38

3. Flow-duration curve computation for Soup Creek above Soup Creek Campground (site 91) 38

4. Mean annual discharge adjustments for selected gaging stations 39

5. Basin characteristics and mean annual discharge for streamflow-measurement sites (1938-82 base period) $\mathbf{4 0}$

6. Discharge for various exceedance percentages for streamflow-measurement sites (1938-82 base period) 43

7. Mean monthly discharge for streamflow-measurement sites (1938-82 base period) 45

8. Basin characteristics and mean annual discharge for streamflow-gaging stations (1938-82 base period) 47

9. Discharge for varous exceedance percentages for streamflow-gaging stations (1938-82 base period) 48

10. Mean monthly discharge for streamflow-gaging stations (1938-82 base period) 49

11. Long-term mean annual discharge computaton for Flower Creek near Libby (site 14) 50

12. Long-term mean annual discharge computation for Bear Creek near Victor (site 59) 51

13. Long-term mean annual discharge computation for Swan River near Condon (site 84) 52

14. Estimated flow-duration curve error for Flower Creek near Libby (site 14) 53

15. Estimated flow-duration curve error for Bear Creek near Victor (site 59) $\mathbf{5 3}$

16. Estimated flow-duration curve error for Swan River near Condon (site 84) 54

17. Estimated long-term mean monthly discharges and errors for Flower Creek near Libby (site 14) 54

18. Estimated long-term mean monthly discharges and errors for Bear Creek near Victor (site 59) 55

19. Estimated long-term mean monthly discharges and errors for Swan River near Condon (site 84) 55

20. Estimating equations for flow-duration curve streamflows in Region $1 \mathbf{5 6}$

21. Estimating equations for flow-duration curve streamflows in Region $2 \mathbf{5 6}$

22. Average prediction error for regression equations $\mathbf{5 7}$

23. Average prediction error for regression equations determined from gaged data only $\mathbf{5 7}$

24. Range of independent variables $\mathbf{5 7}$ 


\title{
Streamflow Characteristics of Mountain Streams in Western Montana
}

\author{
By Charles Parrett and J. A. Hull
}

\begin{abstract}
Once-monthly streamflow measurements were used to estimate long-term mean annual flow, mean monthly flow, and various points on the flow-duration curve for 72 sites in the mountainous areas of western Montana. The estimated flow characteristics at 56 measurement sites, together with data from 22 gaging stations, were used to develop maps showing the variability of mean annual runoff, in inches, for three areas.
\end{abstract}

Data from all measurement sites plus data from 34 gaging stations were used to develop regression equations relating mean annual flow to drainage area and precipitation, and equations relating flows of $10,20,30,40,50,60,70,80$, and 90 percent exceedance probability to mean annual flow. The study area was divided into two regions, with a different set of estimating equations applicable to each region. The estimating equations for mean annual flow had coefficients of determination $\left(R^{2}\right)$ of 0.944 and 0.971 in the two regions, with corresponding standard errors of estimate of 33 and 17 percent. The coefficients of determination for the estimating equations for flows of various exceedance percentages ranged from 0.849 to 0.981 in one region and from 0.889 to 0.971 in the other.

Average errors of prediction were also calculated using data withheld from the regression analyses. The estimated average error for predicting mean annual flow was -16 percent in one region and -23 percent in the other. The estimated average prediction errors for flows of various exceedance percentages ranged from +2 percent to -38 percent in one region and from +18 to -15 percent in the other.

\section{INTRODUCTION}

Recent energy shortages, coupled with the soaring costs of conventional energy sources, have spurred interest in alternative and renewable forms of energy. In the mountainous regions of Montana this interest has focused on the development of small-scale hydroelectric power. Almost 50 applications for preliminary permits for western Montana, under the Federal Energy Regulatory Commission licensing procedures, had been granted or were pending as of November 1983.
The feasibility of small-scale hydropower development depends on the amounts of streamflow available for diversion. Unfortunately, few continuous-record streamflow-gaging stations have been established on small (drainage areas less than about $100 \mathrm{mi}^{2}$ ) mountain streams in Montana. This paucity of data has made it difficult to assess adequately the potential for small-scale hydropower development in Montana.

Previous studies by Boner and Buswell (1970), Farnes (1978), and Potts (1983) provided techniques for estimating mean annual streamflow at ungaged site: in the mountainous areas of Montana. A recent study by Cunningham and Peterson (1983) also provided a procedure for estimating flow-duration curves at potertial hydropower sites in Montana. In each instance, howe rer, the estimating techniques were based on existing streamflow-gaging data and, thus, might not be reliable when applied to ungaged small mountain streams.

Accordingly, the present study was undertaken in cooperation with the Montana Department of Natural Resources and Conservation. The study was conducted to expand the data base for small, mountain streamflows and to refine previously developed estimation techniques.

Annual runoff generally follows the precipitation pattern, with greater amounts occurring in areas of higher elevation. Streamflows vary greatly, on a seasc nal basis: snowmelt provides the bulk of annual runof ${ }^{-}$in May and June, and the smallest streamflows generally occur during fall and winter, when base flows are entirely the result of ground-water inflow.

A significant number of applications for permit: to develop hydropower on a small scale have been for the Yaak River drainage in the northwestern part of the study area and for the Swan River drainage in the eastcentral part. Both areas receive more than 40 in. of precipitation annually, are densely forested, and have numerous small streams with well-formed drainage patterns and steep channels. Although few applications have been made for the Bitterroot River drainage, the west side of the Bitterroot River is similar in topography and climate to the Swan River drainage. This area also re- 
ceives more than 40 in. of precipitation annually, is extremely rugged and densely forested, and may thus have as much hydrologic potential for small-scale hydropower development as the Swan River drainage.

\section{DESCRIPTION OF THE AREA}

The study area includes that part of Montana within the upper Columbia River basin, as shown in figure 1 . This area, generally referred to as western Montana, is characterized largely by north- to northwesttrending mountain ranges separated by long-straight valleys. Except for the valley floor areas, the study area is generally rugged and densely forested. Almost all the potential sites for small-scale hydropower development are located in the rugged mountains of the study area.

Annual precipitation varies greatly in the study area, primarily because of the effects of the mountains. Annual precipitation tends to be greater in the mountains and generally is greater on the western slopes than on the eastern slopes. Most precipitation occurs as snow, although significant amounts of rainfall commonly occur in May and June.

Most of the streamflow-measurement sites were located in the Kootenai River basin and in the Swan River basin, the two areas of current interest in hydropower development. Where possible, the sites were located near main-traveled roads to ensure year-round access. On several streams in each area, more than one measurement site was used to determine streamflow variability within the same drainage; year-round access to most of the additional measuring sites on these streams was not possible. The rest of the 51 sites measured in 1982-83 were located on streams that, from a reconnaissance-level onsite inspection, appeared to have favorable flow characteristics and sufficient fall (slope) for hydropower development.

In addition to the measurements made in 1982-83, this study incorporates miscellaneous streamflow measurements at 21 sites made during earlier investigations. Fifteen of these sites were located in the Bitterroot River drainage, where monthly streamflow measurements were made in 1958-59. Six sites were measured sporadically in 1974-75 as part of a lake tributary study. Because the data collected at these six sites are not complete monthly data, the accuracy of the estimated streamflow characteristics may not be as good as at the other sites.

The locations of the streamflow-measuring sites are shown in figure 1. Descriptions of the measuring-site locations and the measured streamflow data are contained in table 1 at the end of the report.

The method used for estimating streamflow characteristics at the monthly measurement sites requires the use of concurrent and long-term streamflow data from nearby streamflow-gaging stations. In addition, stream- flow-gaging station data from throughout the study area were required to develop a common base period of flow record at all sites used in the analysis. The locations of all the gaging stations used, either for comparison with the monthly measurement sites or for extension of the record, are also shown in figure 1.

\section{STREAMFLOW MEASURING SITES A ND GAGING DATA}

To obtain additional data on stream flow characteristics at potential hydropower sites, 51 streamflowmeasurement sites were established and once-monthly streamflow measurements were made from March 1982 through February 1983. Of these sites, 10 were either active or discontinued crest-stage gage sites. These sites were chosen partly because some data on stage versus streamflow were already available there and partly as a means of minimizing travel costs. Four of the 51 sites were located at discontinued streamflow-gaging stations on Fortine Creek, Big Creek near Rexford, the St. Regis River, and Bear Creek near Essex; measurements at these sites were used for correlation purposes only.

The purposes of this report are to present the streamflow data and to describe the refined techniques for estimating streamflow characteristics developed from these data. Streamflow was measured once monthly at selected potential hydropower sites in western Montana. These data, together with miscellaneous streamflow data and gaging-station data previously collected on mountain streams, were then used to estimate long-term flow characteristics at earh site. The streamflow data and estimating techniques described herein will be useful to hydropower developers, land-use managers, water-rights administrators, and others who need to estimate streamflow characteristics in the mountains of western Montana.

In addition to streamflow data ccllected by the U.S. Geological Survey, flow data were furnished by Bill Schultz of the Montana Division of Forestry, Wally Page of the Flathead National Forest, and Laty Meshew of the Kootenai National Forest. The assistarse and cooperation of these individuals are greatly appreciated.

\section{METHODS OF ANALYSIS}

Expanding the small-stream data base by installing conventional continuous-recording gaging stations would have been prohibitively expensive. In addition, any new stream-gaging station would have to be onerated at least several years to obtain enough data to determine longterm streamflow characteristics. Accordingly, an alternative method based on once-monthly discharge measurements at selected sites was used. 


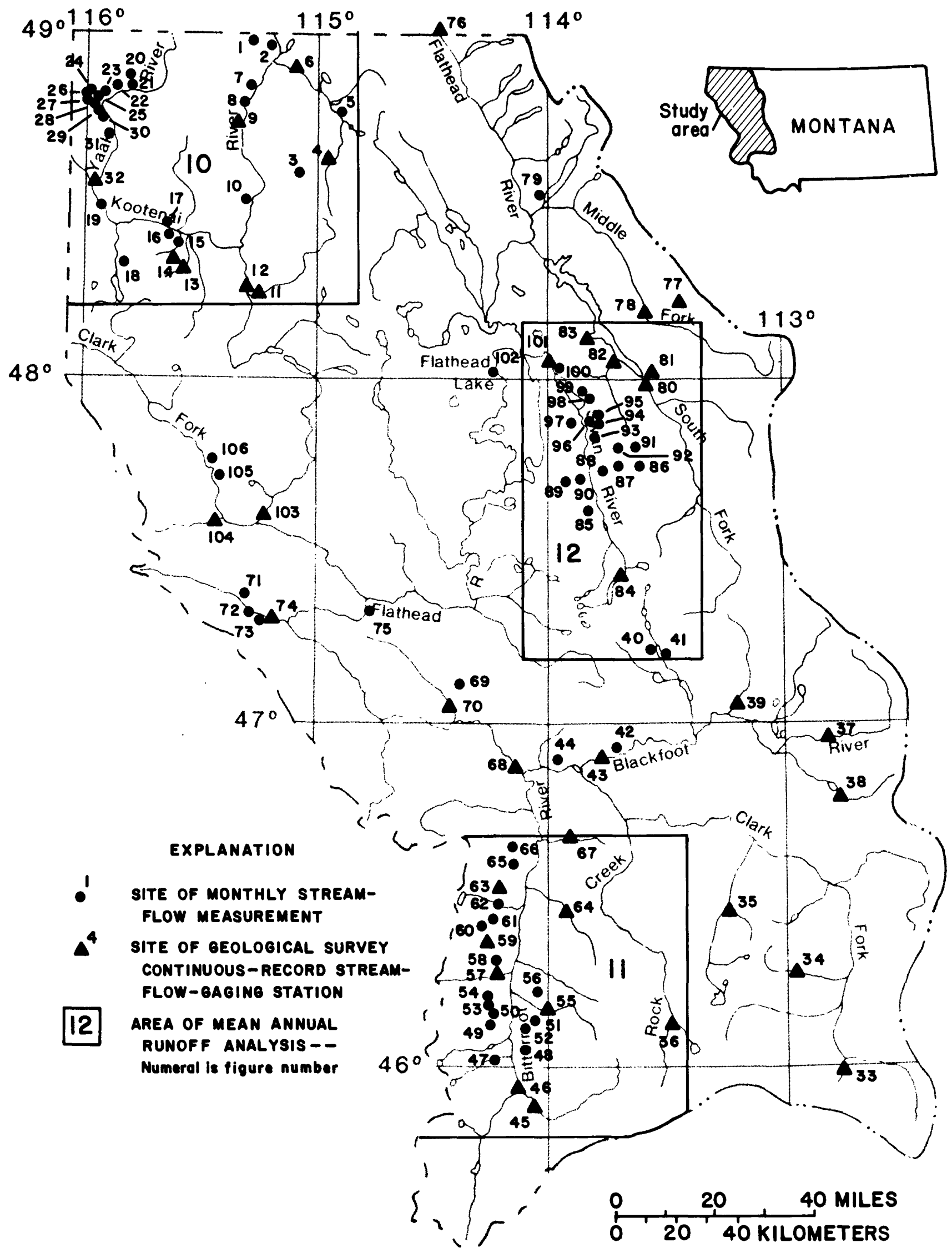

Figure 1. Location of streamflow-measurement sites and gaging stations. 


\section{Estimating Streamflow Characteristics from Discharge Measurements}

Riggs (1969) found that annual mean discharge could be determined from once-monthly discharge measurements with an expected error of about \pm 10 percent. In New York, Hunt (1963) also found that miscellaneous streamflow measurements made during base-flow periods could be used to estimate flow-duration curves with about the same accuracy. In both techniques, the streamflow measurement made at the ungaged site is compared with the daily mean discharge for the same day at a nearby gaging station. If the gaging station is in the same general hydrologic setting as the site in question, the relationship between the daily mean discharge and some streamflow characteristic at the gage can be assumed to be the same at the ungaged site. Thus, for example, if the daily mean discharge at the gaging station is one-half the monthly mean discharge, the measured discharge at the ungaged site is also assumed to be one-half its monthly mean discharge. Likewise, if the daily mean discharge at the gaging station is equal to the 50-percent exceedance discharge on the flow-duration curve, the measured discharge at the ungaged site is also assumed to be equal to the 50-percent exceedance discharge.

To obtain an estimate of the annual mean discharge at an ungaged site, Riggs recommended that discharge measurements be made each month. The measurements are made near the middle of the month on the assumption that a measured discharge at that time is closer to the mean discharge for the month than a measurement made near the beginning or the end of the month. The ratio of the monthly mean discharge to the daily mean discharge is determined for the nearby gaging site for each month. Each monthly ratio is then multiplied by the measured discharges at the ungaged site to estimate monthly mean discharge. The estimated monthly means are then averaged to obtain an estimate of the annual mean discharge for the year the measurements are made. In addition, a graphical plotting of each measured discharge versus the concurrent daily mean discharge at the gaging station can be made on log-log paper. In general, the closer the points plot to a $45^{\circ}$-line, the better the relationship between the ungaged and the gaged site, and the more reliable the estimates of monthly mean discharge. An application of the method is illustrated in table 2 (all tables are at the end of the report), and the plotting of concurrent discharges is shown in figure 2 .

Concurrent discharges are also used to determine flow-duration curves for ungaged sites. From the period of record at the gaged site, the exceedance percentage is determined for each conrurrent daily mean discharge. The same exceedance percentage is assumed applicable to the concurrent streamflow measurement at the ungaged site, and the points are plotted on log-probability paper.
A smooth curve fitted through the points, as shown in figure 3, determines the final estimated flow-duration curve for the same period of record as the gaged site. The flow-measurement data used to constru?t figure 3 are listed in table 3.

\section{Extending Streamflow Records to a Common Base Period}

The techniques just described will provide for an ungaged site an annual mean discharge for the year in which the miscellaneous measurements wore made and a flow-duration curve for the period of record at the concurrent gaging station. Because the length of record at the gaging stations used in this study for convarisons varied from 5 to 45 years, all records were extended to a common base period. This extension was intended to eliminate any bias in the estimated flow characteristics due to short, perhaps unrepresentative, streamflow records.

The method chosen to extend streamflow records was a statistical regression procedure de eloped by the U.S. Army Corps of Engineers (1971). The regression procedure (HEC-4) uses monthly flow data from several streamflow gages in an area to estimate missing monthly flow values for each gage and for each year of record. The model also preserves the variance of the unadjusted short-term record by adding a random component to the estimated values. Starting with the first year of data, missing monthly streamflows are estimater at all stations for each month in sequence. Thus, when $\varepsilon$ missing flow is being estimated, there is always a valid value for all stations already examined that month and for all remaining stations in either the current or the preceding month. The equation for estimating missing flows hav the following general form:

$$
\begin{aligned}
Q_{i, j}=B_{1} Q_{i, 1} & +\ldots+B_{j-1} Q_{i, j-1}+B_{j} Q_{i-1, j} \\
& +B_{j+1} Q_{i, j+1}+\ldots+B_{n} Q_{i, n}+\sqrt{1-R_{i, j}{ }^{2}} \cdot\left(Z_{i, j}\right)
\end{aligned}
$$

where

$Q_{i, j}$ is the monthly flow logarithm, expressed as a standard normal deviate, for month $i$ and station $j$,

$B_{j}$ is the beta coefficient for station $j$ computed from a correlation matrix of flows at all $n$ stations,

$R_{i, j}$ is the multiple correlation coefficiont for month $i$ and station $j$, and

$Z_{i, j}$ is a random number generated from a standard normal population. 


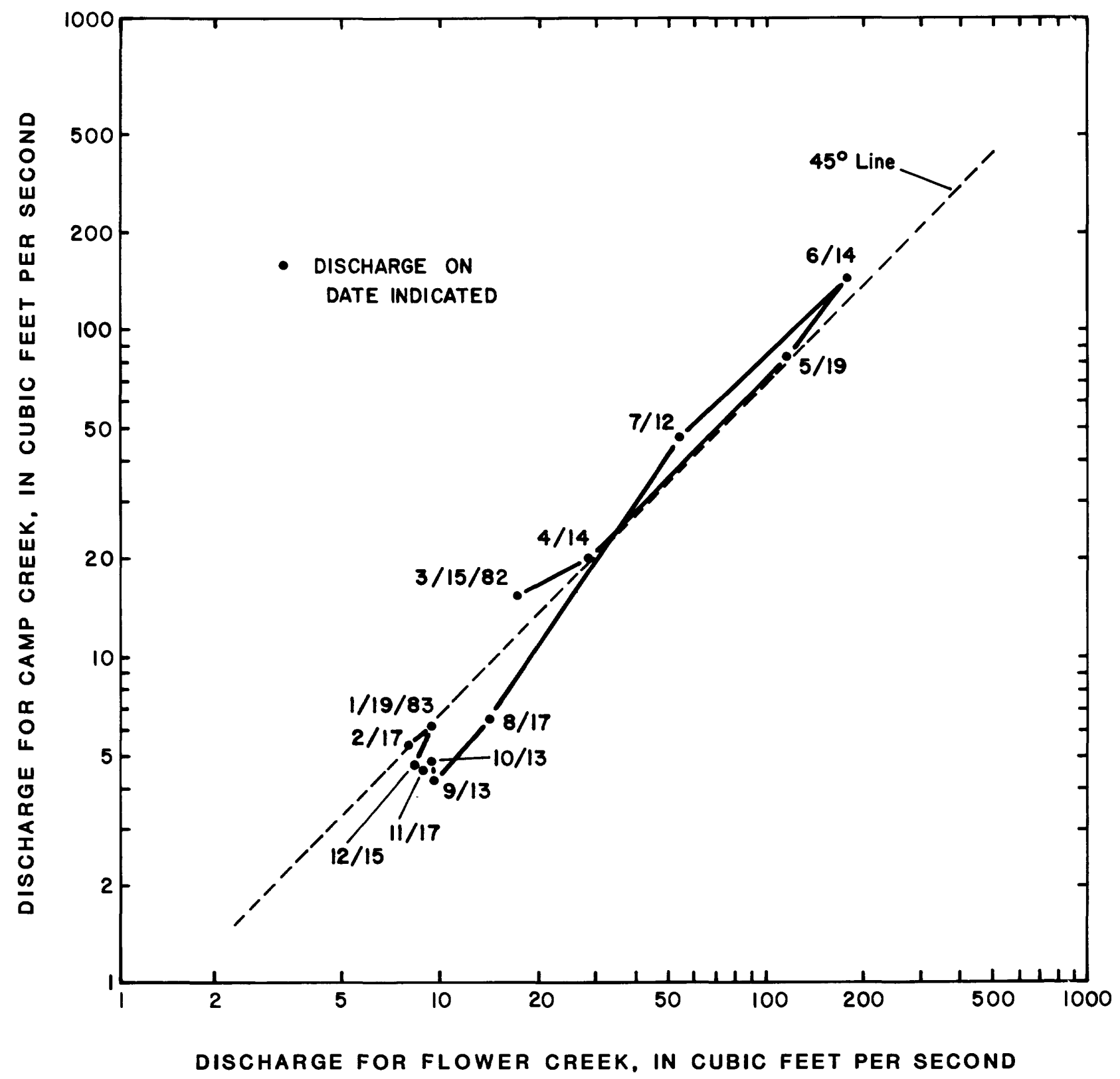

Figure 2. Concurrent discharges on Camp Creek and Flower Creek. 


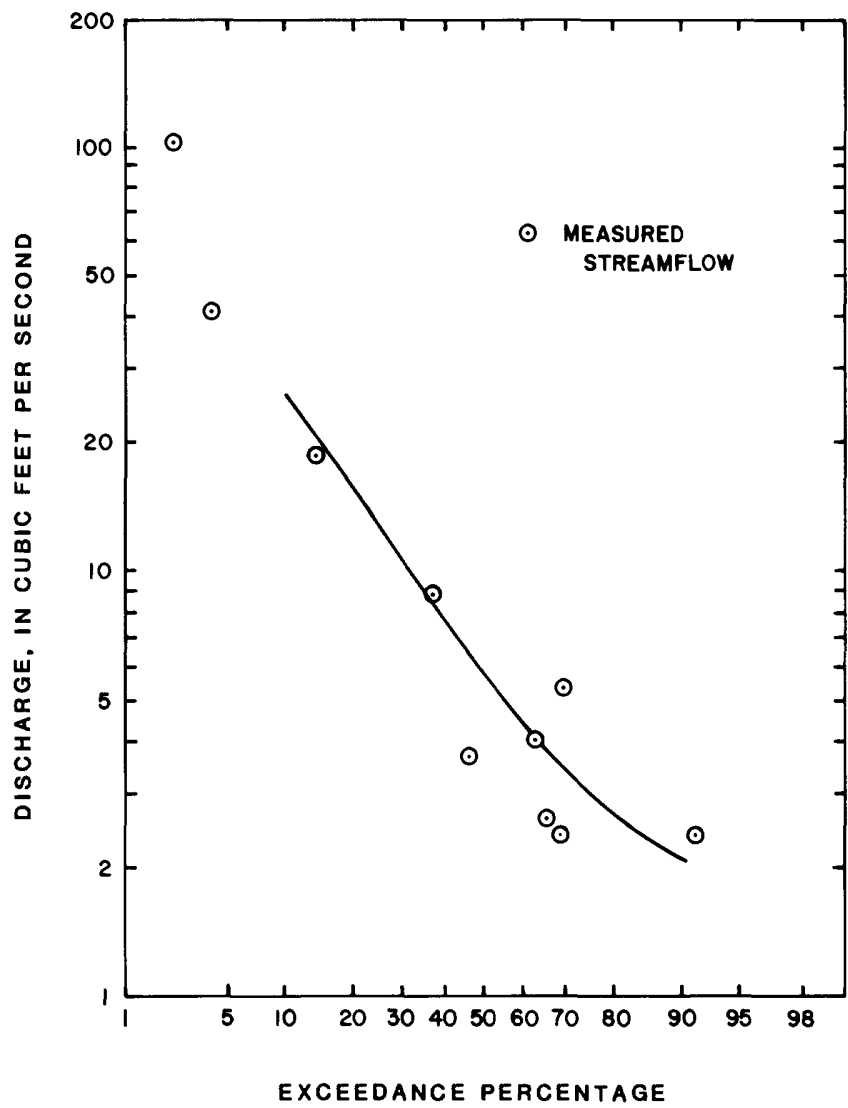

Figure 3. Estimated flow-duration curve for Soup Creek above Soup Creek Campground.

If any station being used to estimate a missing monthly flow is also missing a flow value for that month $(i)$, then the flow for the preceding month $(i-1)$ is used in the right side of equation 1. If, for example, the monthly flow at station 1 and month $i$ were missing, the first term on the right side of equation 1 would be $B_{1} Q_{i-1,1}$.

The HEC -4 procedure was used to develop a common record from water year 1938 to water year 1982 at 38 gaging stations in western Montana. Of these 38 gaging stations, 20 were subsequently used as concurrent flow stations for determining annual mean discharges and flow-duration curves at ungaged sites. The 20 gaging stations and the results of the long-term mean annual discharge adjustments are listed in table 4.

\section{Estimating Long-Term Streamflow Characteristics}

To obtain an estimate of the long-term mean annual discharge from an estimate of one annual mean, data from nearby gaging stations were used. In the northwestern part of the study area (Kootenai River drainage), five gaging stations with active record from March 1982 to February 1983 (sites 6, 14, 32, 103, and 104) were used to develop a regression equation for estirating long-term mean annual discharge from the annual mean discharge for March 1982 to February 1983. The equation thus derived is:

$$
Y=0.88 X^{1.00},
$$

where

$Y$ is the long-term mean annual discharge and

$X$ is the annual mean discharge for March 1982 to February 1983.

In the Bitterroot drainage, seven gaging stations with active record during the 1958 wate- year (sites 36 , $46,55,57,59,64$, and 67 ) were used to develop a similar regression equation relating the long-term annual discharge to the annual mean discharge for 1958. The resulting equation is:

$$
Y=1.11 X^{0.99},
$$

where

$Y$ is the long-term mean annual discharge and

$X$ is the annual mean discharge for the 1958 water year.

For the rest of the study area (Clark Fork drainage), four gaging stations with active record for March 1982 to February 1983 (sites 39, 43, 70, and 84) were used to develop the following regression equation:

$$
Y=0.77 X^{1.00},
$$

where the terms are the same as defined for equation 2 . The plots of the three regression equations thus developed are shown in figure 4 . The regre sion equations were used to calculate a long-term mean annual discharge at each flow-measurement site where tho annual mean discharge for the measurement year had previously been estimated.

As discussed earlier, flow-duration curves were prepared for the ungaged flow-measurement sites using the period of record at the nearby gaging stations. To convert the derived flow-duration curves to t1 $\cdot 1938-82$ base period, the following procedure was used. At 26 gaging stations with essentially natural flow, six I' 'ear regression equations were developed relating daily fows of 10,20 , $30,50,70$, and 90 percent exceedance percentages to mean annual discharge for the period of record. The six equations and their respective coefficients of determination $\left(R^{2}\right)$ are: 


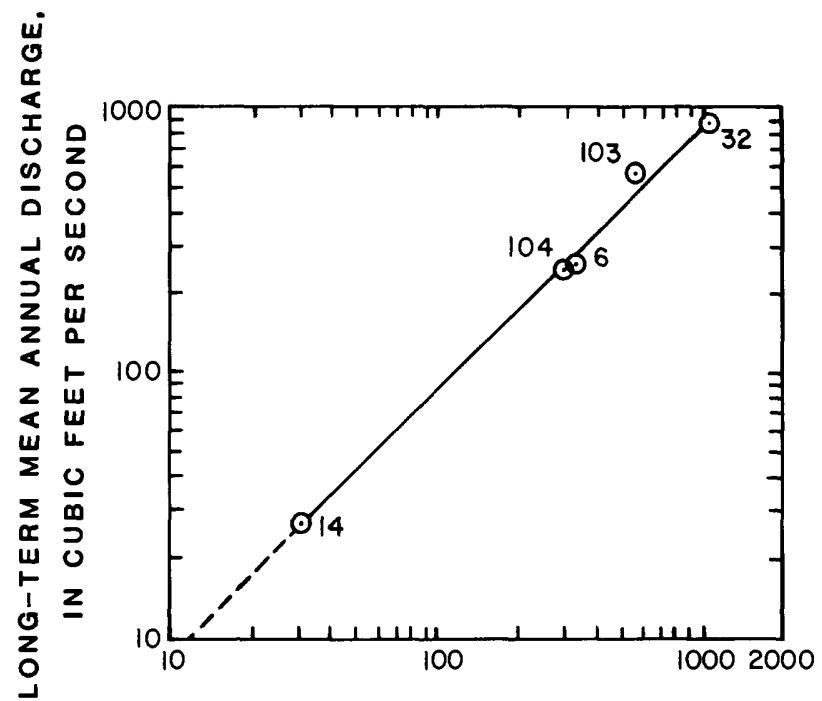

ANNUAL MEAN DISCHARGE FOR 1982-83 MEASUREMENT YEAR, IN CUBIC FEET PER SECOND

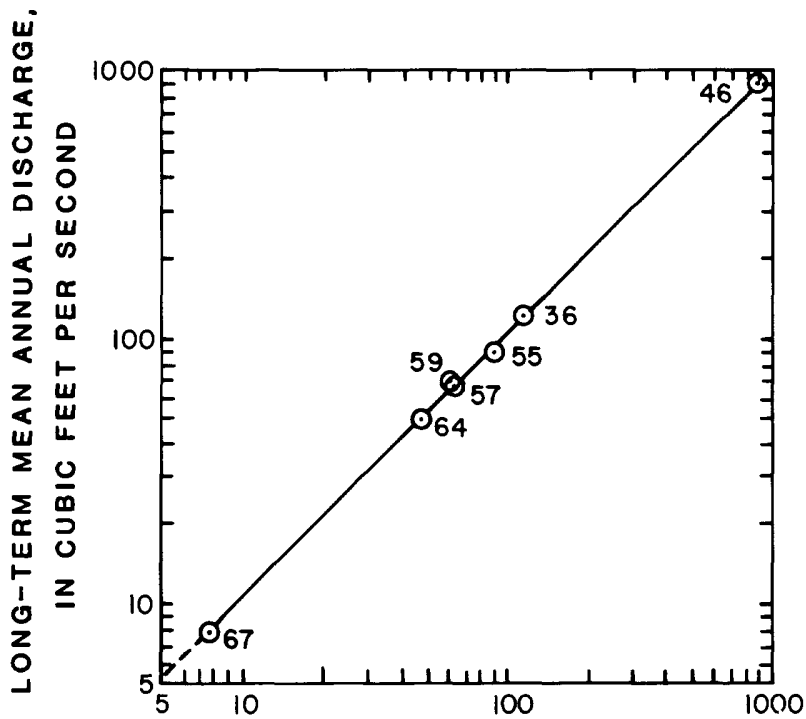

ANNUAL MEAN DISCHARGE FOR 1958 WATER YEAR, IN CUBIC FEET PER SECOND

B. Bitterroot River drainage

A. Kootenai River drainage
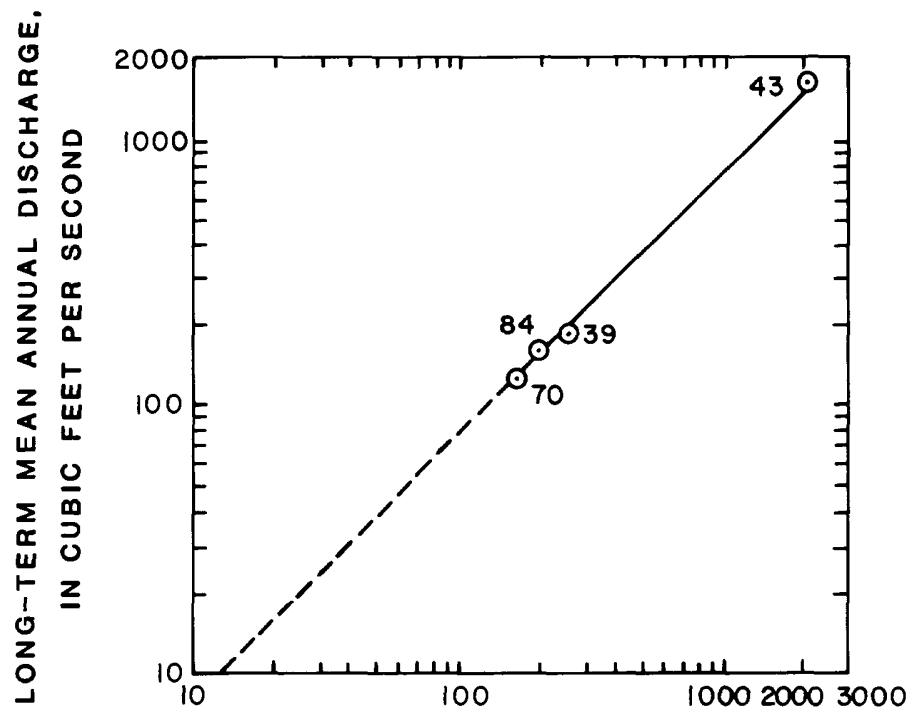

ANNUAL MEAN DISCHARGE FOR 1982-83

MEASUREMENT YEAR, IN CUBIC FEET PER

SECOND

C. Clark Fork drainage

Figure 4. Regression equations relating long-term mean annual discharge to one annual mean discharge. 


$\begin{array}{ll}Q_{10}=-21.66+3.01 Q_{A} & R^{2}=1.00 \\ Q_{20}=-24.46+1.49 Q_{A} & R^{2}=1.00 \\ Q_{30}=1.29+0.72 Q_{A} & R^{2}=0.98 \\ Q_{50}=8.37+0.35 Q_{A} & R^{2}=0.96 \\ Q_{70}=7.76+0.24 Q_{A} & R^{2}=0.95 \\ Q_{90}=6.94+0.17 Q_{A} & R^{2}=0.94\end{array}$

where

$Q_{i}$ is the daily flow with an exceedance percentage of $i$, which ranges from 10 to 90 , and

$Q_{A}$ is the mean annual discharge for the period of record.

To obtain the regression coefficient (the number multiplied by $Q_{A}$ ) for any exceedance percentage, a smooth curve relating the coefficient to exceedance percentage was drawn, as shown in figure 5. To compute a point on the long-term (1938-82 base period) flowduration curve for an ungaged site, the difference between the long-term mean annual discharge and the mean

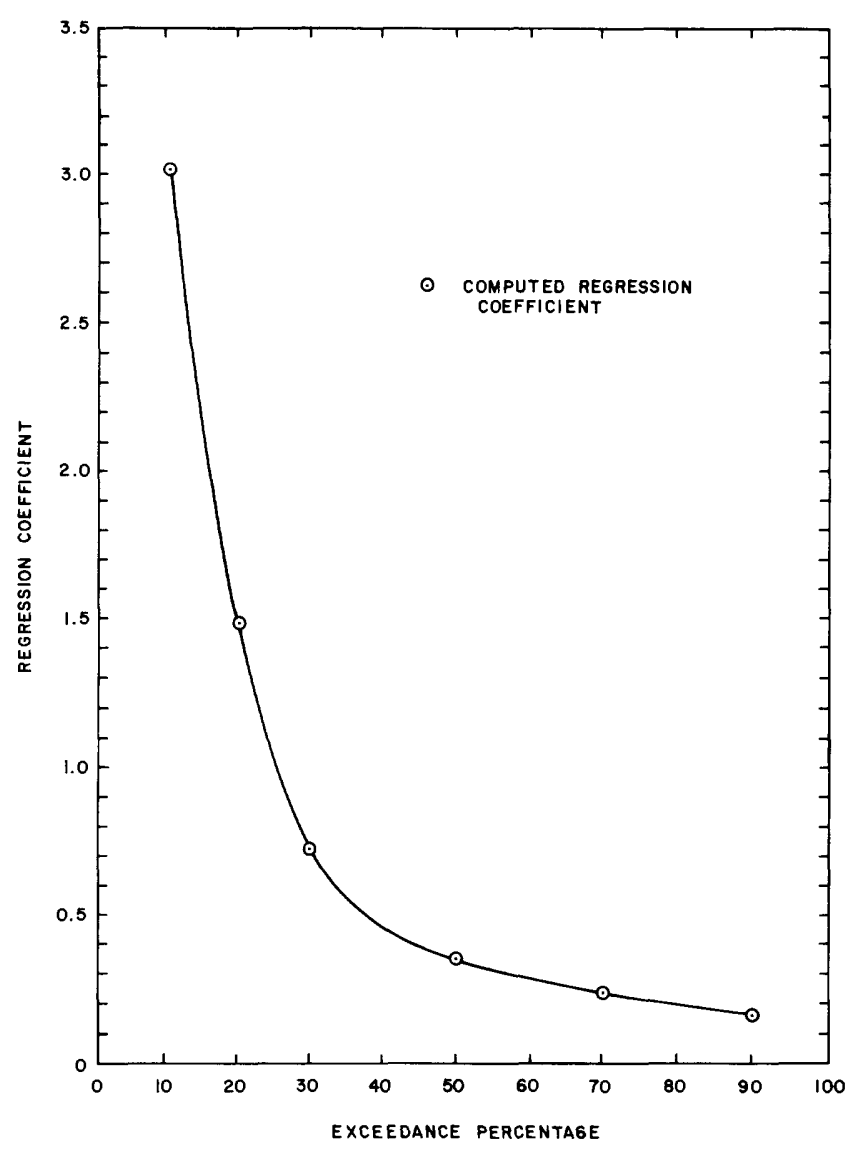

Figure 5. Relationship of regression coefficient to exceedance percentage. annual discharge for the period of record is calculated for the nearby gaging station used to estimate the flowduration curve. This difference is multiplied by the appropriate regression coefficient in figure 5 and is algebraically added to the flow value determined from the estimated flow-duration curve.

To illustrate, assume that the flow-duration curve for an ungaged site was estimated usir? the methods previously described. Further assume that the flowduration curve shows that the 10-percent exceedance discharge is $210 \mathrm{ft}^{3} / \mathrm{s}$. At the nearby gaging station, the mean annual discharge for the period of record is assumed to be $30 \mathrm{ft}^{3} / \mathrm{s}$, and the long-term mean annual discharge is assumed to be $40 \mathrm{ft}^{3} / \mathrm{s}$. The adjusted long-term daily discharge with an exceedance percentage of 10 is computed for the ungaged site as follows:

$$
\begin{aligned}
Q^{\prime}{ }_{10} & =3.01\left(Q_{A}{ }^{\prime}-Q_{A}\right)+Q_{10} \\
& =3.01(40-30)+210 \\
& =240 \mathrm{ft}^{3} / \mathrm{s}
\end{aligned}
$$

where the terms with primes are long-term values.

To compute long-term mean montr- 1 y discharges at the ungaged measurement sites, several techniques were tried. The first was to adjust the montr'y mean values already computed as a part of the procedure to determine annual mean flow. This technique was discarded because the error associated with an individual monthly mean estimate was too large; tests with gaging station data showed that individual monthly mean est 'nates could be in error by as much as 40-50 percent, even when the annual mean flow estimates were within 10 percent. Computing long-term monthly estimates directly by using the ratio of the concurrent daily discharge at a gaging station to the long-term mean monthly discharga at the gaging station did not improve the estimates. The technique finally used to estimate long-term mean monthly discharges at the ungaged measurement sites was to assume that the same monthly distribution of anrual flow would occur at the ungaged measurement site as at some nearby gaging station. Thus, if the long-term mean annual discharge at an ungaged measurement site were estimated to be $23 \mathrm{ft}^{3} / \mathrm{s}$, and if the long-term mean October discharge at a similar gaging station were determined to be 4.1 percent of the long-term mean annual discharge at the gaging station, then the best estimate of the long-term mean discharge for October at the ungaged measurement site would be 4.1 percent of $23 \mathrm{ft}^{3} / \mathrm{s}$, or $0.9 \mathrm{ft}^{3} / \mathrm{s}$.

Adjustments to the computed long-term mean monthly discharges were made subjectively when it was known that the streams on which the un ?aged measurement sites were located functioned differently from the gaged streams considered most similar. $\mathrm{P}$-rmenter Creek (site 15), for example, becomes completely dry in late summer, but none of the nearby stream- monitored by 
gaging stations do so. Conversely, South Woodward Creek near its mouth (site 90) has a fairly even discharge, whereas the nearby gaged streams show a large seasonal variation in discharge. The general variation in monthly streamflow at gaging stations within the study area is illustrated in figure 6. The final, long-term streamflow characteristics estimated for each ungaged measurement site and for selected streamflow-gaging stations are given in tables 5 through 10.

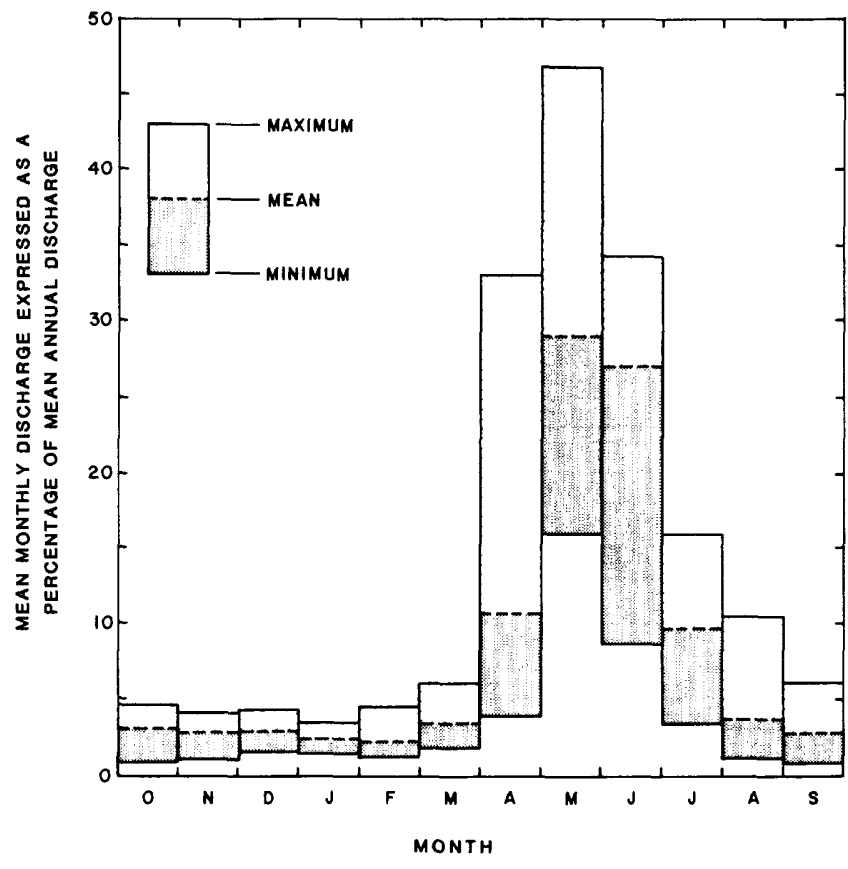

Figure 6. Range of mean monthly discharges at gaging stations.

\section{APPRAISAL OF ACCURACY}

The accuracy of the streamflow estimates made at ungaged sites by using the monthly measurement technique cannot be determined directly. An indication of the accuracy can be obtained, however, by applying the technique to gaged sites for which long-term streamflow data are available. Accordingly, one gaged site in each of the three major areas of potential hydropower development was chosen as the site where streamflow estimates were required. A gaged site suitable for comparison purposes was selected, and the daily mean discharge on the 15 th of each month was used to make the monthly and annual mean discharge estimates and the flow estimates for selected points on the flow-duration curve. The sites for which flow estimates were made were Flower Creek near
Libby (site 14), Bear Creek near Victor (site 59), and Swan River near Condon (site 84). The sites used as nearby concurrent-flow gaging stations were, respectirely, Yaak River near Troy (site 32), Bitterroot River near Darby (site 46), and Monture Creek near Ovando (site 39). The results of the accuracy tests for determinin ? an annual mean discharge and the long-term mean annual discharge are given in tables 11-13.

As indicated by tables 11-13, the estimates of a single annual mean discharge have an error range (percent difference) of -3 to -11 percent. The estimate: for long-term mean annual discharge range in error from -2 to -15 percent. Because the three test streams are considered to be generally representative of the streams actually measured, it is concluded that the estimates of long-term mean annual discharge have an average error of about \pm 10 percent.

The estimated flow-duration curves for the three test streams are plotted in figures 7-9. The plotted points are taken from tables 11-13, and final values from the smoothed curves and the associated errors are listet in tables 14-16. The average error for the estimated f'owduration curves ranged from 6 to 17 percent. The curation curves estimated for the ungaged flow measurement sites are thus believed to have a comparable average error of $10-15$ percent.

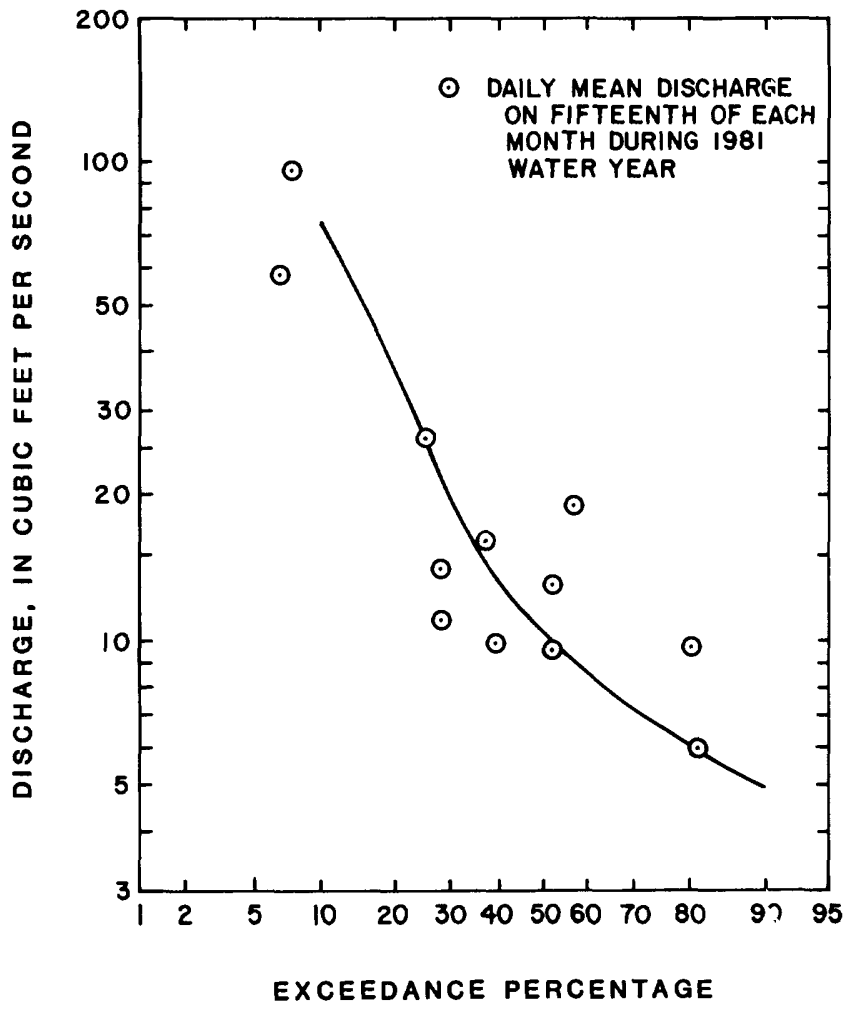

Figure 7. Estimated flow-duration curve for Flower Creek near Libby. 


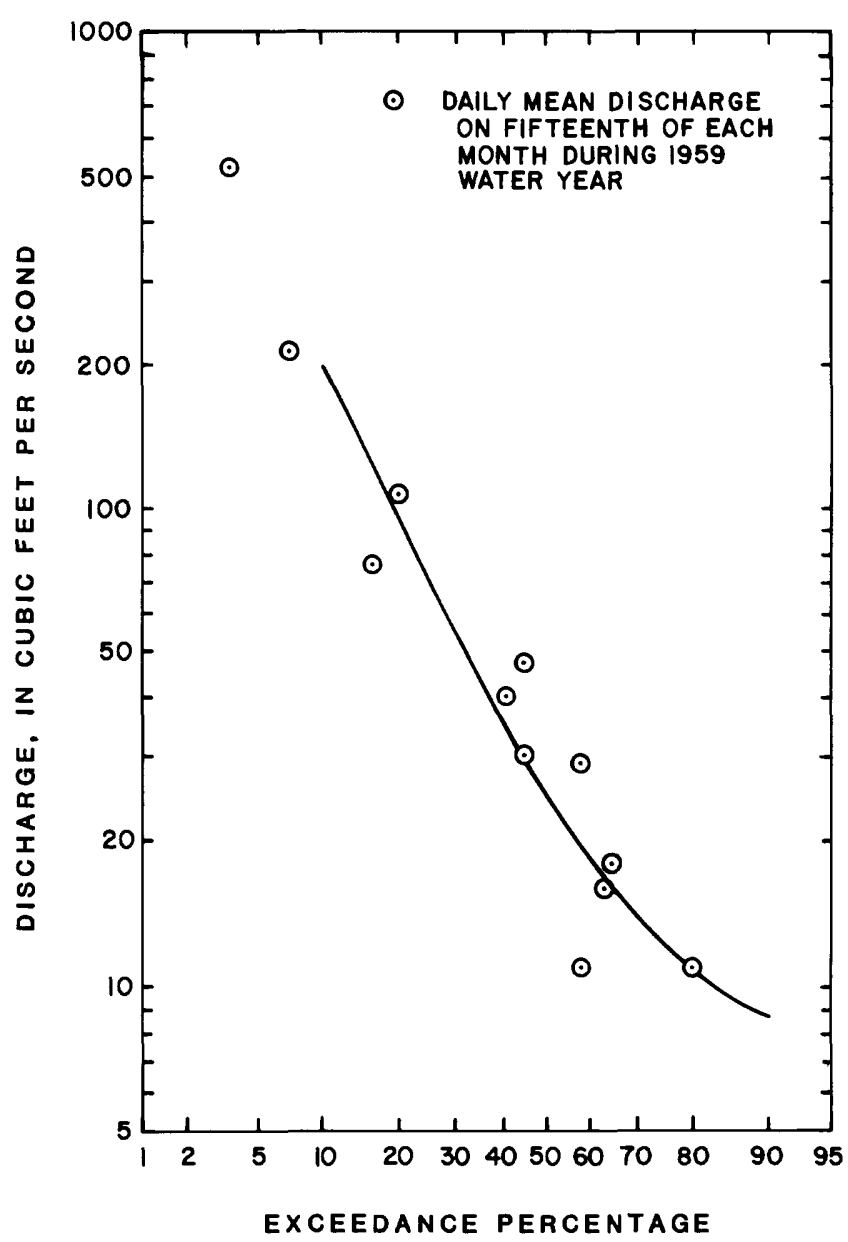

Figure 8. Estimated flow-duration curve for Bear Creek near Victor.

The estimated long-term mean monthly discharges and the associated errors for the three test sites are given in tables 17-19. As indicated by the tables, the errors associated with the estimates of mean monthly discharge are much more variable and generally larger than the errors for estimating the mean annual discharge or the flow-duration curve. For each of the three test streams, at least one mean monthly discharge estimate was in error by more than 40 percent. On two of the test streams, the largest error for a monthly mean estimate exceeded 50 percent. The mean monthly discharge estimates made for the measurement sites are believed to have comparably large errors. The accuracy of the mean monthly flow estimates could be significantly improved only if more than one flow measurement per month were used or if the once-monthly flow-measurement program were continued for several years.

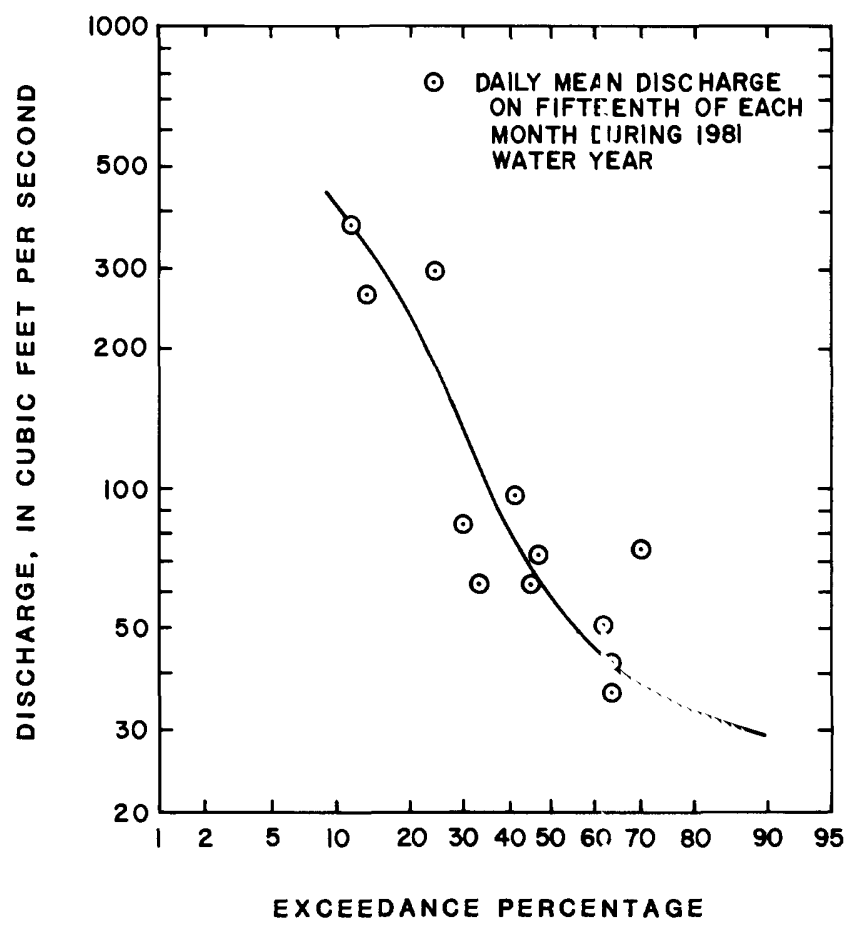

Figure 9. Estimated flow-duration curve for Swan River near Condon.

\section{VARIATIONS IN MEAN ANNUAL R' JNOFF}

To more fully explore the variations in mean annual runoff throughout the study area, the three areas with the greatest concentrations of streamflow gages and flow-measurement sites are shown in detail in figures 10-12. Each figure shows the site number and location of each streamflow measurement site ard streamflowgaging station in the area. Also shown $\mathrm{i}^{-}$the long-term mean annual runoff at each site.

The first area is in the northwestern part of the study area and includes most of the Kootenai River drainage in Montana (fig. 10). As shown by the lines on the map, mean annual runoff generally increases from east to west in the Kootenai River area. The greatest annual runoff occurs in the mountainous regions southwest of Libby and west of the Yaak River. The streams in the Yaak River drainage having multiple measuring sites indicate that annual runoff generally increases with elevation. Lines of equal mean annual runoff were drawn in figure 10 by assuming that the computed values of mean annual runoff were effectively located at the centroids of the individual drainage basins. Elevation and maps showing average annual precipitation (U.S. So:l Conservation Service, 1977) were used as a guide in draving lines where no runoff data were available. The lines of equal mean 


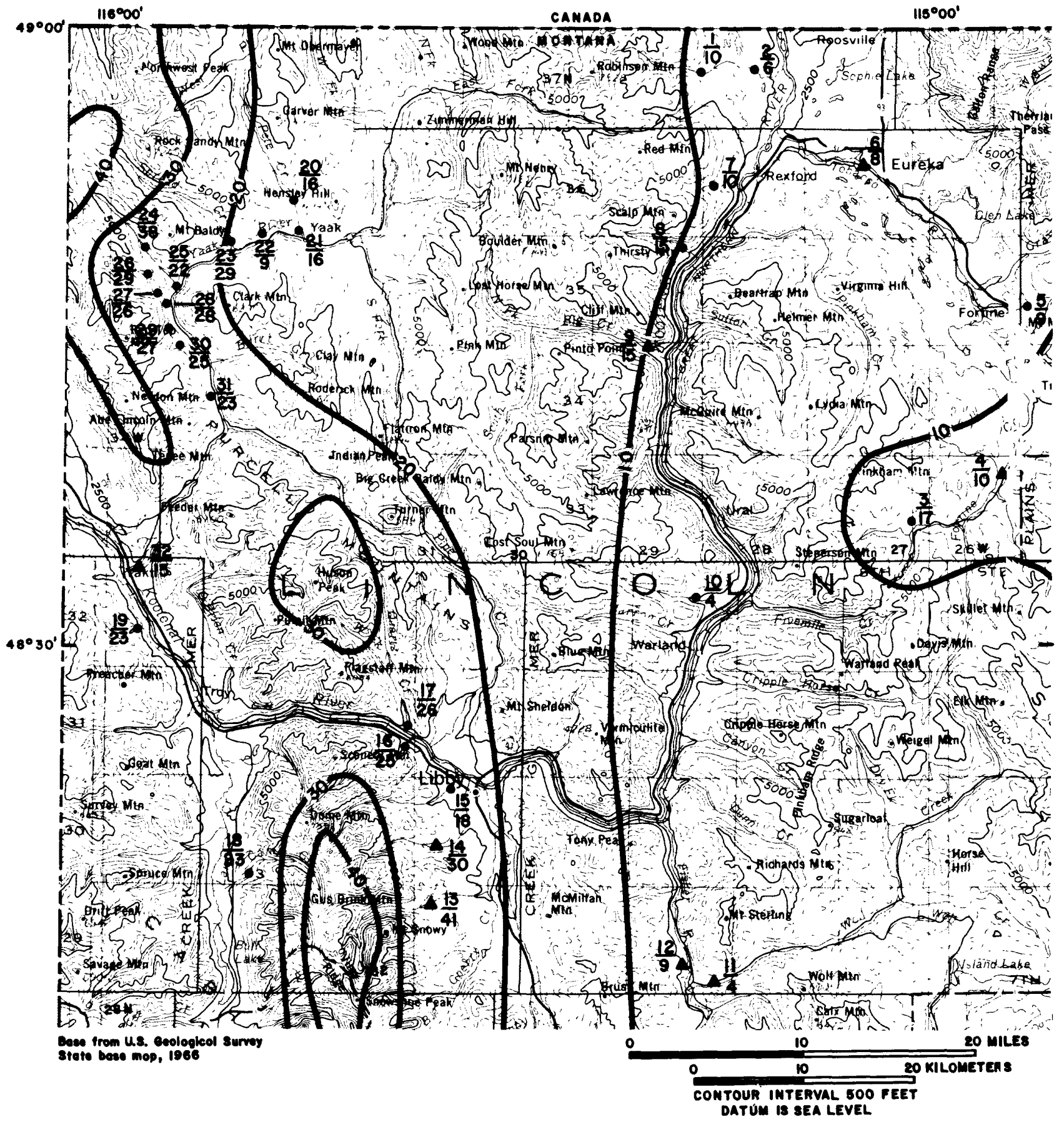

explamation

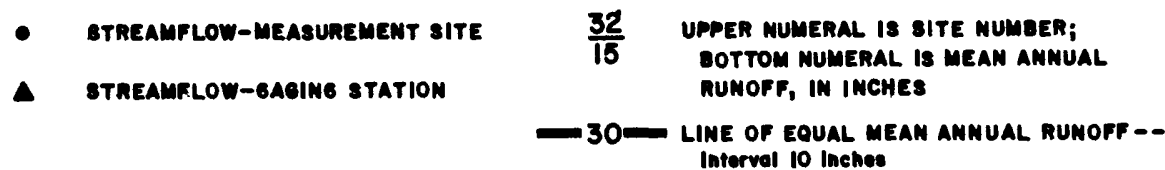

Figure 10. Mean annual runoff in the Kootenai River area. 


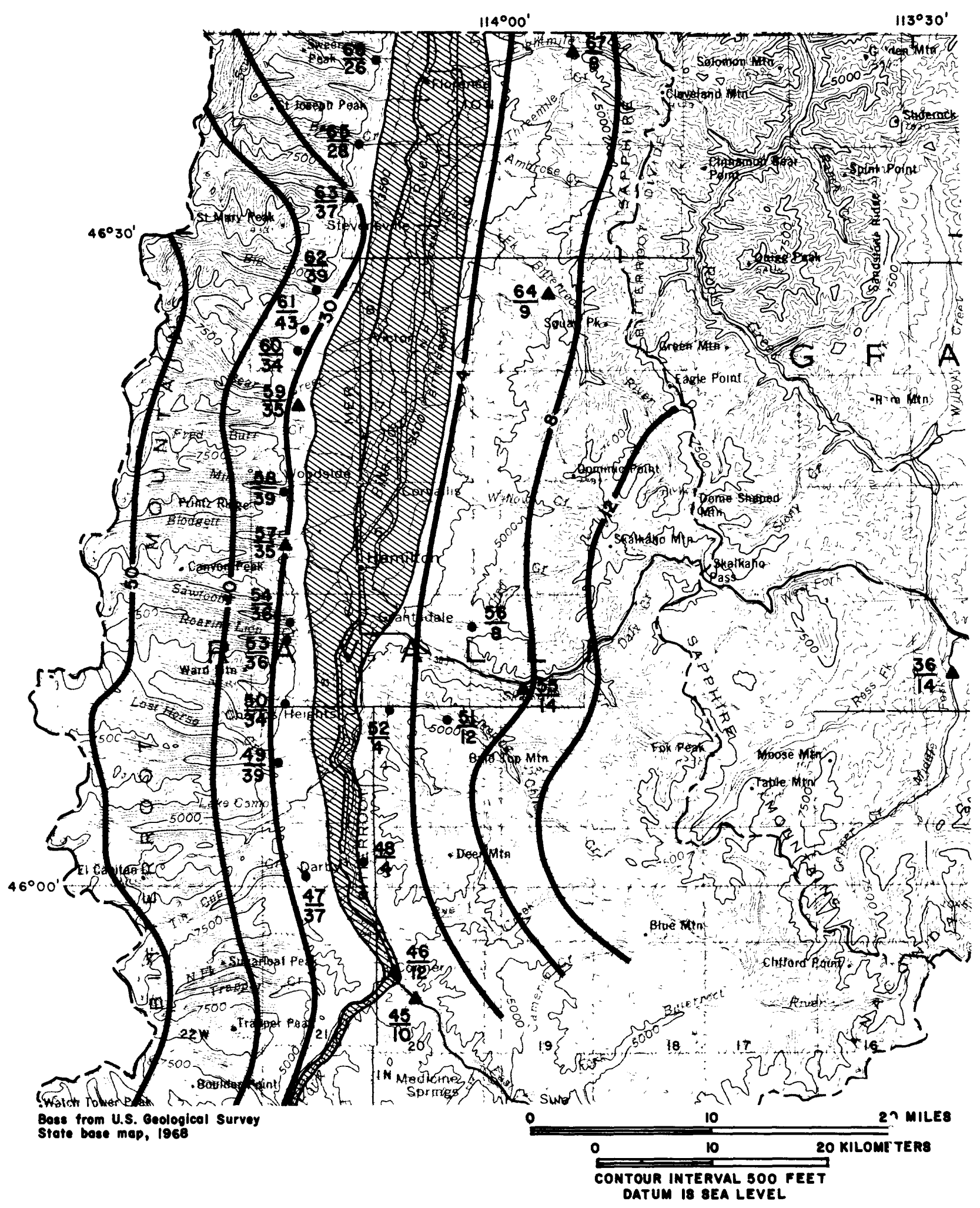

EXPLANATION

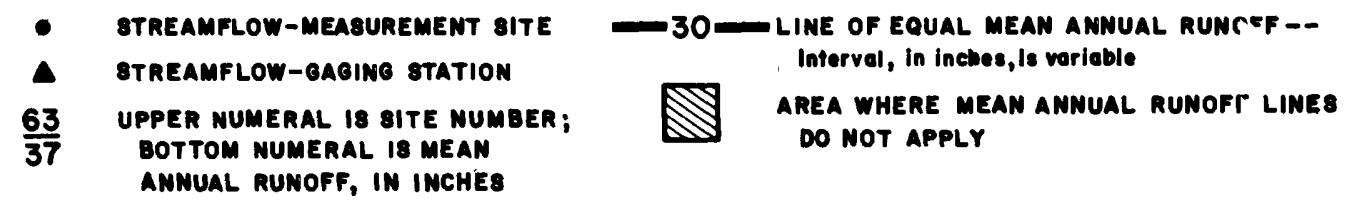

Figure 11. Mean annual runoff in the Bitterroot River area. 


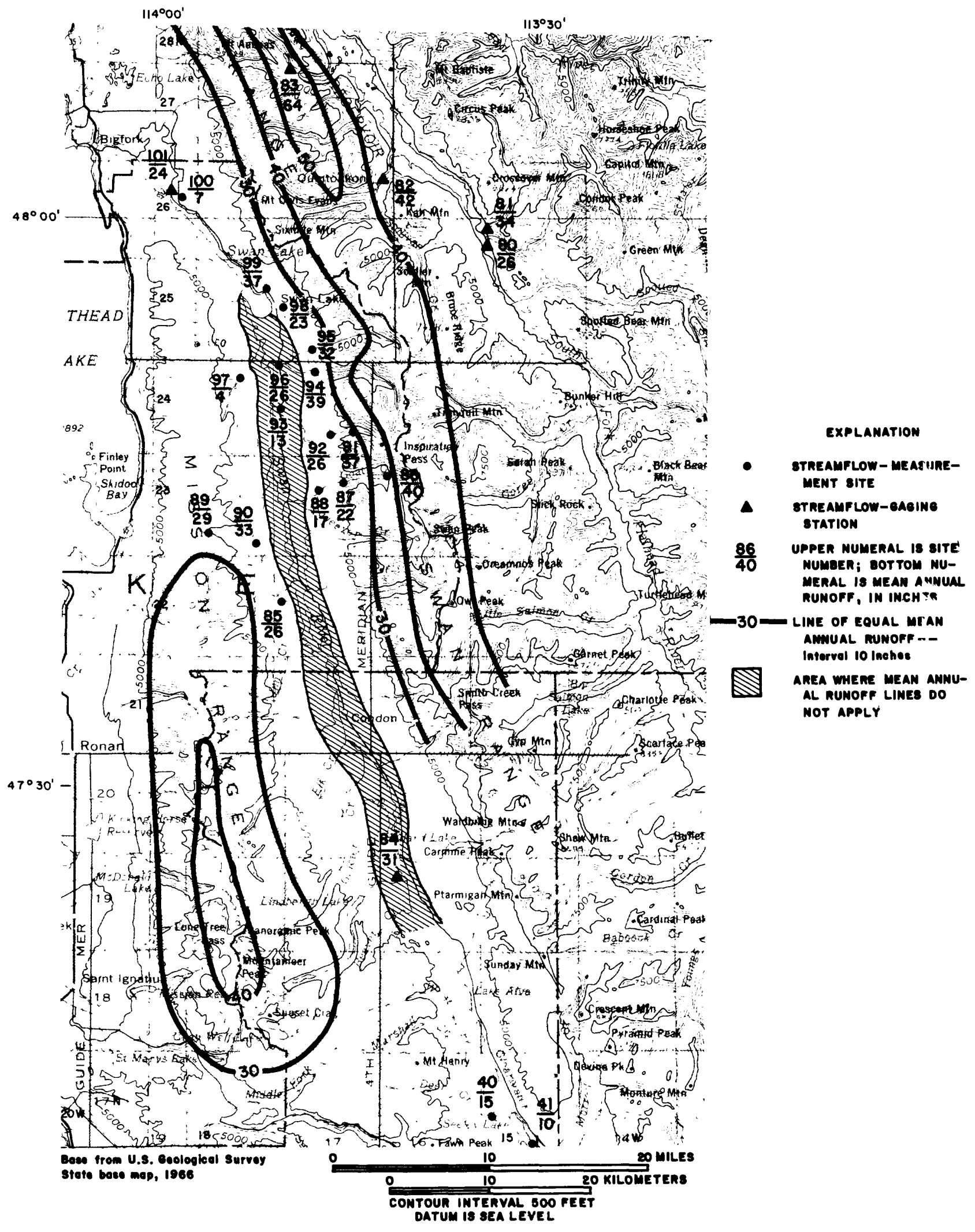

Figure 12. Mean annual runoff in the Swan River area. 
annual runoff can be used to estimate mean annual runoff at any ungaged site in the area. It needs to be emphasized, however, that mean annual runoff is determined at the centroid of the drainage area upstream from the site and not at the site itself. Also, the locations of the lines are based on a limited number of flow-measurement sites, and considerable variation between the lines is possible.

The second area is composed largely of the Bitterroot River drainage (fig. 11). In this area, mean annual runoff varies markedly from the east side of the Bitterroot River, where computed values range from 4 to 14 in., to the west side of the Bitterroot River, where mean annual runoff ranges from 26 to 43 in. On the west side, the computed values of mean annual runoff are consistent from south to north, except for the two northernmost streams, Bass Creek and Sweeney Creek (sites 65 and 66). Although multiple measuring sites were not used on streams in the Bitterroot area, mean annual runoff was assumed to increase with elevation, and the lines of equal mean annual runoff were drawn accordingly. A previous study by McMurtrey and others (1972) indicated that streams on the west side of the Bitterroot River generally lose a substantial amount of their flow when they leave the mountain canyons and flow over the porous alluvium of the valley floor. Consequently, the lines of equal mean annual flow shown in figure 11 will not provide accurate estimates of mean annual flow at locations on the valley floor.

The third area is drained by the Swan River and the South Fork Flathead River (fig. 12). Mean annual runoff tends to be greater on the east side of the Swan River than on the west side, although the east-west variation is not as pronounced as in the Bitterroot area. Mean annual runoff also generally increases from south to north on the east side of the Swan River. The multiple measuring sites in the Swan River area indicate a large increase in mean annual runoff from the valley floor to the mountains. As in the Bitterroot area, substantial streamflow losses evidently occur as the mountain streams enter the alluvium of the valley floor. Consequently, the lines of equal mean annual runoff will not provide accurate estimates of mean annual flow in the valley-floor area.

Several anomalies in the general pattern of mean annual runoff variation also occur in the Swan River area. Porcupine Creek (site 97) and Johnson Creek (site 100 ) both have mean annual runoff values substantially smaller than those from any nearby measuring site. These streams may traverse sections of very permeable or fractured bedrock that intercept a large percentage of the annual streamflow. Also, the mean annual runoff of South Woodward Creek evidently is increased by springs between measuring sites 89 and 90 . These anomalies serve to emphasize that generalized maps such as figures 10-12 can be used to accurately estimate mean annual runoff only where local geology and ground-water/surfacewater interactions remain fairly uniform.

\section{EQUATIONS FOR ESTIMATING STREAMFLOW CHARACTERISTICS}

Because maps of mean annual runoff could be developed for only three parts of the western Montana study area, prediction equations for estimating mean annual discharge anywhere in the study area were derived using multiple regression techniques. Prediction equations relating streamflows for various points on the flowduration curves to mean annual discharge were also developed using multiple regression.

\section{Mean Annual Discharge}

To estimate mean annual discharge, a multipleregression equation of the following log-linear form was derived:

$$
Q_{A}=a A^{b} P^{\mathcal{C}}
$$

where

$Q_{A}$ is mean annual discharge in cubic feet per second,

$A$ is drainage area,

$P$ is mean annual precipitation,

$a$ is the regression constant, and

$b$ and $c$ are regression coefficients.

Drainage area is expressed in square mile and is determined for ungaged sites by planimetering the area outlined on the best-scale topographic map available. Mean annual precipitation is the basin average, in inches, determined from the maps of the U.S. Soil Conservation Service (1977). No other basin characteristics such as basin elevation or channel slope were consideret for inclusion in the regression equations because previnus studies by Potts (1983) and Farnes (1978) showed no other variables to be significant in estimating mean annual discharge. An equation for the entire study area was first. derived using data from 92 streamflow-measuring sites and gaging stations. Examination of the residuals from the preliminary regression equation indicated that better results would be obtained if the study area were separated into two regions. Consequently, the study area was divided into the two regions shown in figure 13.

In Region 1, data from 47 sites were used to develop the following regression equation:

$$
Q_{A}=0.0165 A^{0.974} P^{1.159},
$$




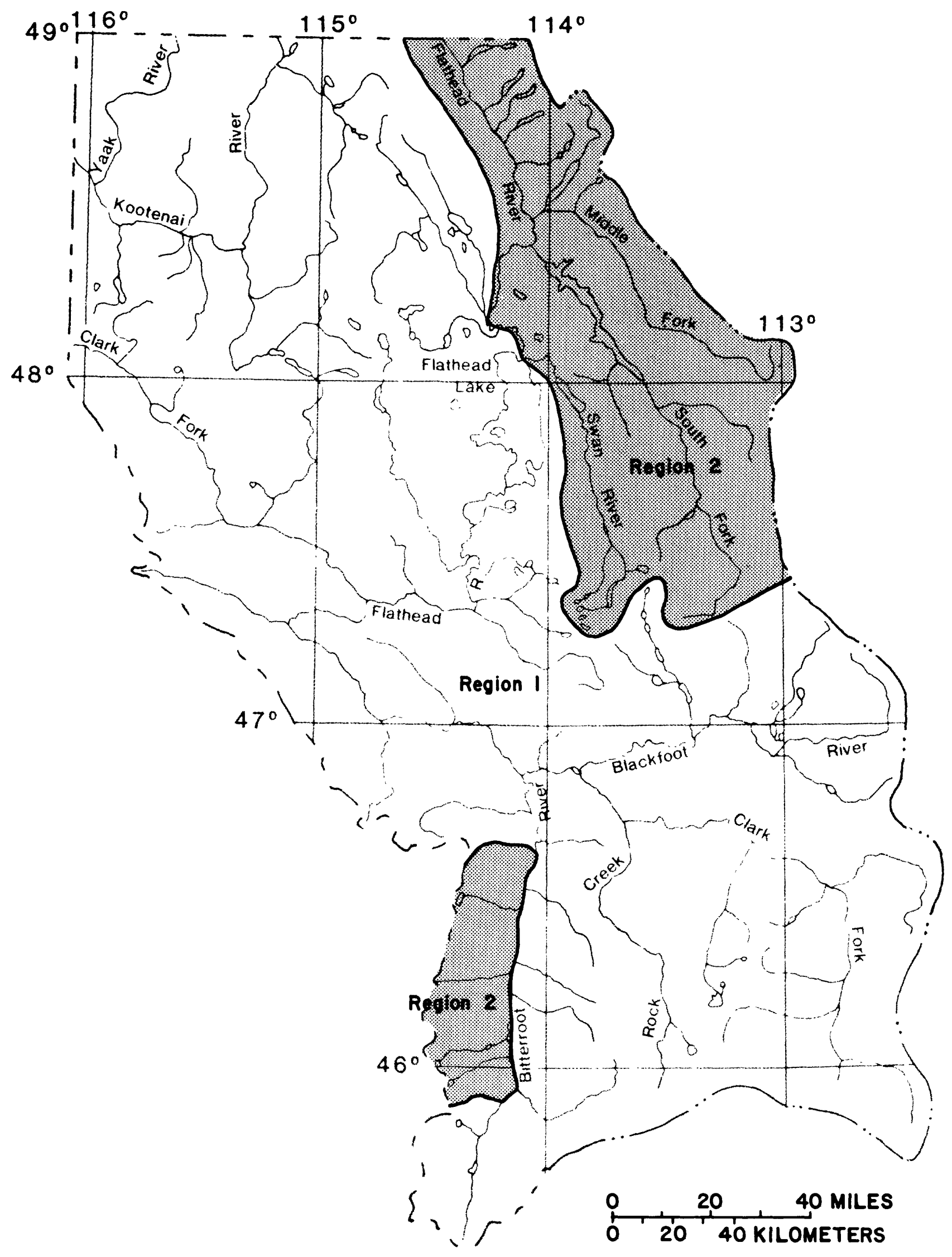

Figure 13. Regional boundaries. 
where the terms are as previously defined. The coefficient of determination $\left(R^{2}\right)$ for this prediction equation was 0.944 , and the standard error of estimate was 33 percent. The prediction equation developed by Potts for the same general area as Region 1 (Region 3 in the Potts report) is similar:

$$
Q_{A}=0.0292(A \cdot P)^{1.003} .
$$

Equation 13 yields estimates of mean annual discharge that are slightly larger than those from equation 12. For a drainage area of $10 \mathrm{mi}^{2}$ and a mean annual precipitation of $10 \mathrm{in}$., the result from equation 13 is about 32 percent larger than the result from equation 12 . For a drainage area of $10 \mathrm{mi}^{2}$ and a mean annual precipitation of 40 in., the result from equation 13 is about 7 percent larger. Because equation 12 was developed specifically for mountainous areas and smaller streams (drainage areas smaller than $100 \mathrm{mi}^{2}$ ) in western Montana, equation 12 is probably more reliable than equation 13 in those instances.

Region 2 includes the west side of the Bitterroot River drainage and the Swan River and Flathead River drainages. This region corresponds generally with Region 4 defined by Potts (1983). The regression equation for mean annual discharge derived for Region 2 was based on data from 24 sites and is:

$$
Q_{A}=0.0313(A \cdot P)^{1.045} .
$$

The coefficient of determination was 0.971 , and the standard error of estimate was 17 percent. The corresponding prediction equation developed by Potts is:

$$
Q_{A}=0.0411(A \cdot P)^{0.995} \text {. }
$$

Again, equations 14 and 15 are very similar. In this instance, the Potts equation yields larger estimates of mean annual discharge for values of drainage area $(A)$ times mean annual precipitation $(P)$ to a maximum of about 200 . For values of $A \cdot P$ greater than 200 , equation 14 gives larger estimates of mean annual discharge. For a value of $A \cdot P$ of 50 , the difference between equations 14 and 15 is about 8 percent, and for a value of $A \cdot P$ of 10,000 , the difference is about 17 percent. As before, equation 14 is considered to be slightly more reliable than equation 15 when applied to smaller streams in mountainous areas of Region 2.

\section{Flows of Various Exceedance Percentages}

Regression equations for estimating flows for various exceedance percentages were also developed for Regions 1 and 2. For these areas, the equations derived were log-linear regression equations relating flows of various exceedance percentages to mean annual flow. The form of the estimating equations was:

$$
Q_{n}=a Q_{A}^{b},
$$

where

$Q_{n}$ is the daily discharge, in cubic feet per second, for exceedance percentage of $n$,

$a$ is the regression constant,

$b$ is the regression coefficient, and

$Q_{A}$ is the mean annual discharge, in cubic feet per second.

The equations developed for Region 1 and their corresponding coefficients of determination are listed in table 20. Similarly, the estimating equations for flows of various exceedance percentages in Region 2 are given in table 21.

The coefficients of determination ir tables 20 and 21 are all close to 1.00 , indicating very good correlation between mean annual discharge and flows of various exceedance percentages. In both regions, the coefficients of determination generally increase as the streamflows being estimated increase. Low flows (exceedance percentages greater than 50) thus are not as closely correlated with mean annual discharges as are the higher flows (exceedance percentages less than 50 ).

The equations for estimating discharges of various exceedance percentages can be compared with results obtained by Cunningham and Peterson (1983) by first dividing each equation by $Q_{10}$. Thus, in Region 1 , the right side of each equation in table 20 must be divided by $2.866 Q_{A}{ }^{0.995}$, and in Region 2 the right side of each equation in table 21 must be divided by $1.390 Q_{A}{ }^{1.170}$. Solving the dimensionless equations for Region 1 for the smallest and largest values of $Q_{A}\left(2.00\right.$ and $\left.888 \mathrm{ft}^{3} / \mathrm{s}\right)$ produces two dimensionless flow-duration curves that are compared in figure 14 with the dimensionless flow-duration curves developed by Cunningham and Pterson (1983). Similarly, the dimensionless equations for Region 2 were solved for the smallest and largest values cf $Q_{A}$ in region $2\left(6.20\right.$ and $\left.210 \mathrm{ft}^{3} / \mathrm{s}\right)$, and the resulting flow-duration curves are compared in figure 15 with the Cunningham and Peterson curves.

The two curves defined by Cunningr am and Peterson were considered applicable in all mountainous regions of Montana and thus are the same curves in both figures 14 and 15 . The upper curve definet by Cunningham and Peterson represents the expected flow response of mountain streams having the most stab'e streamflows. According to Cunningham and Peterson, such streams are generally located in densely forested areas with deep soil cover and have relatively flat slopes. The lower curve defined by Cunningham and Peterson is remresentative of mountain streams having the greatest variation in stream- 


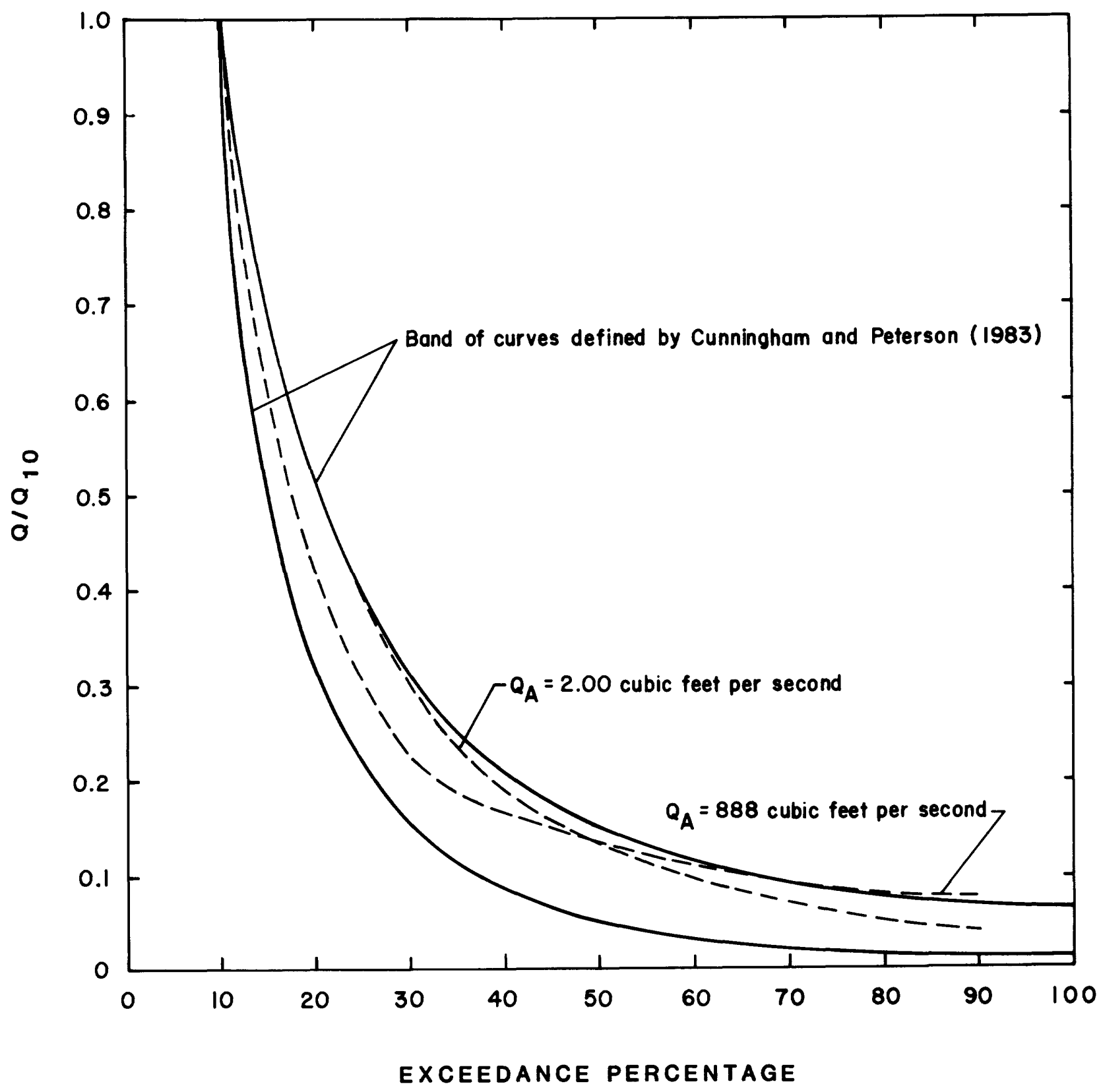

Figure 14. Dimensionless flow-duration curves for Region 1.

flow. Such sites, according to Cunningham and Peterson, are generally characterized by steep, rocky terrain with thin soil cover.

In Region 1, the dimensionless flow-duration curve for the smallest mean annual discharge lies totally within the band of curves defined by Cunningham and Peterson (fig. 14). The curve for the largest mean annual discharge falls well within the band of curves for smaller exceedance percentages, but lies slightly above the band for exceedance percentages greater than 70 . The pronounced flattening of the curve indicates that base flows on streams having large mean annual discharges generally tend to be more constant than those on streams having small mean annual flows.

In Region 2, the curve for the largest mean annual discharge lies totally within the band defined by Cunningham and Peterson, but the curve for the smallest man annual discharge lies above the band for exceedance percentages between 20 and 80 (fig. 15). In this reginn, streamflows evidently fluctuate more on streams ha'ing large mean annual discharges than on streams having small mean annual discharges. This result may reflect the fact that many of the measuring sites on small streams (those having small mean annual discharges) in this re- 


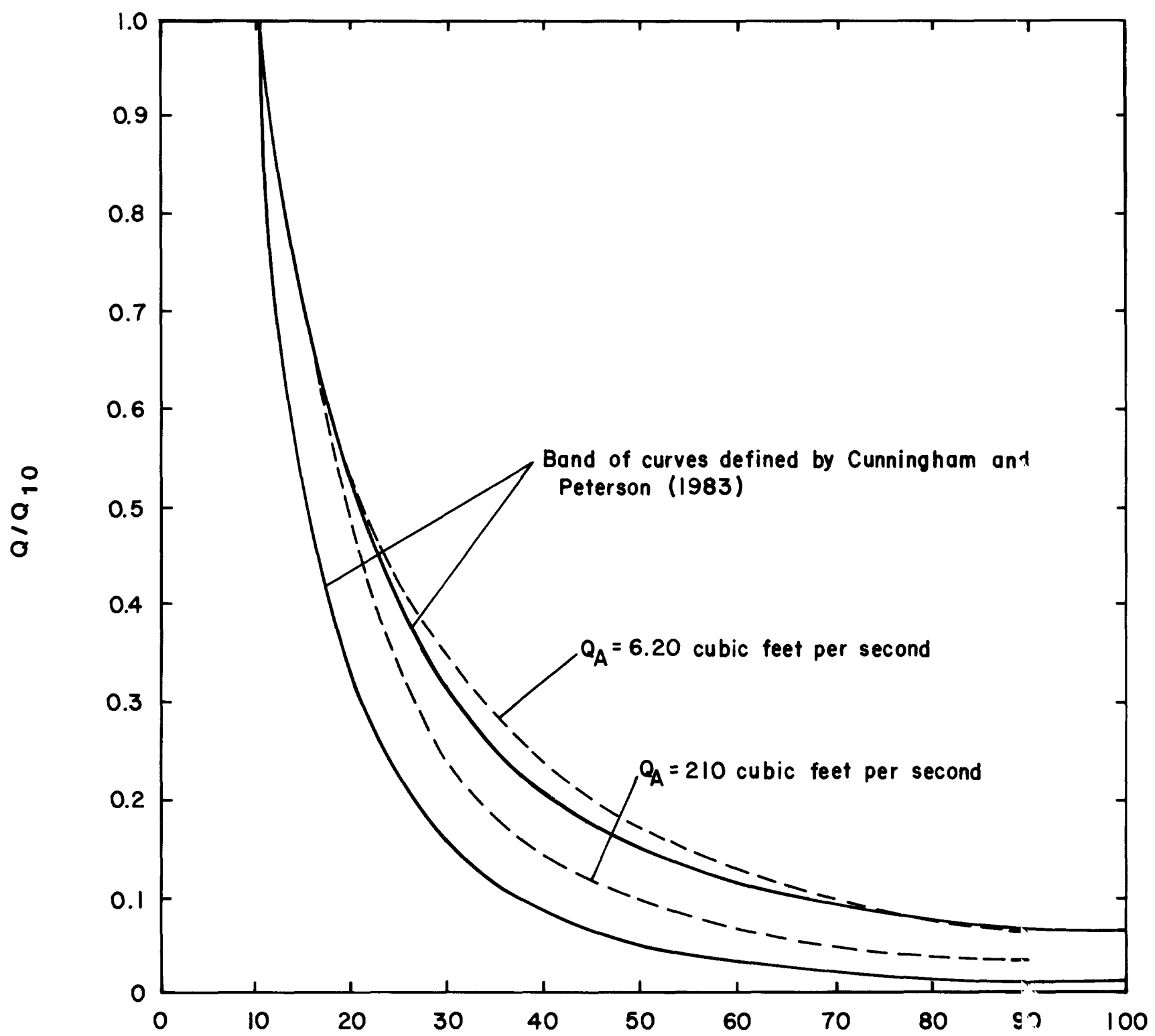

\section{EXCEEDANCE PERCENTAGE}

Figure 15. Dimensionless flow-duration curves for Region 2.

gion were located at higher elevations, where snowmelt is more gradual and takes place over a longer period of time than at lower elevations.

Because the curves developed in this study plot fairly closely to the band of curves defined by Cunningham and Peterson, the results obtained from either method probably will not be significantly different in most instances. The equations in tables 20 and 21 are considered to be more reliable for the study area than the dimensionless curves developed by Cunningham and Peterson, primarily because of the additional small-stream data used.

\section{Prediction Accuracy and Limitations}

Using the equations in tables 20 and 21 to estimate flow for any exceedance percentage requires an estimate of mean annual discharge. The error associated with an estimate of a flow of any exceedance percentage is thus composed of the error associated with making the mean annual discharge estimate as well as the error associated with the estimating equations in tables 20 and 21 . To obtain an indication of the prediction accuracy of the equations in tables 20 and 21 as well as the predirtion accuracy 
of the equations for mean annual flow (eq. 13, 15), 10 sites in Region 1 and 5 sites in Region 2 were randomly selected and withheld from the regression analysis. Applying the estimating equations to the 15 sites not used resulted in the average errors of prediction given in table 22.

Somewhat surprisingly, perhaps, in both regions the average prediction error for flows of most exceedance percentages is less than the prediction error for mean annual discharge. In each region, however, the calculated prediction error for mean annual discharge was largely affected by one poor estimate. If the single poor estimate is eliminated, the average prediction error for mean annual discharge becomes -6 percent for Region 1 and -11 percent for Region 2.

Because the long-term flow characteristics at the flow-measurement sites were determined by correlation with gage sites, and because the correlations reduced the actual site-to-site variability of streamflow, it might be argued that the computed prediction errors are artificially small. To test this assumption, the average errors of prediction were recalculated using only the 6 gage sites from among the 15 sites withheld from the regression analyses. This recalculation reduced the number of sites for calculating average prediction error to five in Region 1 and to only one in Region 2. The average prediction errors calculated using only the six gage sites are given in table 23.

Because the prediction errors calculated from the gage data only are generally less than the prediction errors calculated from all 15 randomly selected sites, the results in table 22 are considered to approximate the average error that can be expected from an estimate of streamflow at an ungaged site. As with any regression analysis, however, it needs to be emphasized that the equations are valid only within the range of values of the variables used to derive the equations and only for locations within the study region. For this study, the range of values of the independent variables is listed in table 24 . Extrapolation beyond the range of values listed or application to sites outside the study area may give unrealistic estimates of streamflow.

The regression equations are also not applicable to mountain streams that are spring-fed or that periodically go dry because of very permeable streambeds or other unique localized geologic features. The equations thus are not applicable to the valley-floor areas of the Bitterroot River and Swan River drainages. The equations also may not be applicable for sites where upstream storage in lakes and ponds is significant, or for sites that have upstream diversions. Some knowledge of the local hydrology and geology is a necessary prerequisite to the successful application of the regression equations. In some instances, a program of monthly streamflow measurements may be required to ascertain whether flow conditions in an area are unique. When very accurate flow estimates are required, the prediction equations can be supplemented and verified by miscellaneous streamflow measurements.

\section{SUMMARY}

Miscellaneous measurements were used to estimate streamflow characteristics at 72 sites in the mountainous areas of western Montana. The characteristics incl ided mean annual discharge, mean monthly discharge, and points on the flow-duration curve. A streamflowcorrelation program permitted synthesizing the missing record at 38 gaging stations in the study area to deve'sp a common 1938-82 period of record at all streamflowmeasurement sites. Tests of the accuracy obtained when miscellaneous measurements are used to estimate longterm streamflow characteristics indicated that mean annual flow can be estimated at a measurement site with an expected error of about \pm 10 percent. The flow-duration curve can be estimated at a streamflow-measurement site with an expected error of about 10-15 percent. Estimates of long-term mean monthly flow have the poorest accuracy, with expected errors of as much as +60 pe"cent and -21 percent.

The estimates of long-term mean annual flow were used, together with applicable gaging data, to prepare maps showing the areal variability of mean annual runoff. The maps were prepared for the three areas in western Montana having the greatest concentration of flow-measurement sites and gaging stations.

Streamflow characteristics determined for the streamflow-measurement sites and gaging stations were also used to develop regression equations for estimating mean annual flow and flows of various exceedance percentages anywhere within western Montana. The best results were obtained when the study area was dividec into two regions, with separate equations for each region. The regression equations for mean annual discharge used drainage area and mean annual precipitation as independent variables and had determination coefficierts of 0.944 and 0.971 in the two regions, with corresponding standard errors of estimate of 33 and 17 percent. The mean annual flow equations were compared with similar equations developed in a previous study and were found to give differences of 7 to 32 percent.

The regression equations for flows of various exceedance percentages used mean annual discharge $\approx s$ the only dependent variable and had coefficients of determination ranging from 0.849 to 0.981 . The equations were converted to a dimensionless form and were compared graphically with results from a previous $s^{t} u d y$. Data from sites not used in the regression analyses were used to develop estimates of expected average errc's of prediction when applying the equations to ungaged sites. 
The estimated average error for mean annual discharge was -16 percent in one region and -23 percent in the other, but would have been reduced to -6 percent and -11 percent had one poor estimate been excluded. The estimated errors for flows of various exceedance percentages ranged from +2 to -38 percent in one region and from +18 to -15 percent in the other.

\section{REFERENCES CITED}

Boner, F. C., and Buswell, G. W., 1970, A proposed streamflow data program for Montana: U.S. Geological Survey open-file report, $96 \mathrm{p}$.

Cunningham, A. B., and Peterson, D. A., 1983, A procedure for estimating flow-duration curves for ungaged mountainous and high plains streams in Montana: Montana University Joint Water Resources Research Center, 43 p.
Farnes, P. E., 1978, Hydrology of mountain watersheds: U.S. Soil Conservation Service, $8 \mathrm{p}$.

Hunt, O. P., 1963, Use of low-flow measurements to estimate flow-duration curves: U.S. Geological Survey Professional Paper 475-C, p. C196-C197.

McMurtrey, R. G., Konizeski, R. L., Johnson, M. V., and Bartells, J. H., 1972, Geology and water resources of the Bitterroot Valley, southwestern Montana: U.S. Geological Survey Water-Supply Paper $1889,80 \mathrm{p}$.

Potts, D. F., 1983, Streamflow regionalization in western Montana: School of Forestry, University of Montana Research Note 19, 5 p.

Riggs, H. C., 1969, Mean streamflow from discharge measurements: International Association of Scientific Hydrology Bulletin 14, p. 95-110.

U.S. Army Corps of Engineers, 1971, HEC-4 monthly streamflow simulation: Hydrologic Engineering Center, $113 \mathrm{p}$.

U.S. Soil Conservation Service, 1977, Averag: annual precipitation, Montana, based on 1941-1970 bese period: Bozeman, Mont., $13 \mathrm{p}$. 
TABLES 1-24 
Table 1. Streamflow measurements and site descriptions [ft, foot; $\mathrm{ft}^{3} / \mathrm{s}$, cubic foot per second; mi, mile]

\begin{tabular}{|c|c|c|c|c|c|}
\hline $\begin{array}{l}\text { Site } \\
\text { No. }\end{array}$ & $\begin{array}{l}\text { Stream } \\
\text { name }\end{array}$ & $\begin{array}{l}\text { Tribu- } \\
\text { tary } \\
\text { to }\end{array}$ & Location & Date & $\begin{array}{l}\text { Dis- } \\
\text { charge } \\
\left(\mathrm{ft}^{3} / \mathrm{s}\right)\end{array}$ \\
\hline \multicolumn{6}{|c|}{ Kootenai River Basin } \\
\hline 1 & $\begin{array}{l}\text { Young } \\
\text { Creek } \\
\text { below } \\
\text { South } \\
\text { Fork }\end{array}$ & $\begin{array}{l}\text { Kootenai } \\
\text { River }\end{array}$ & 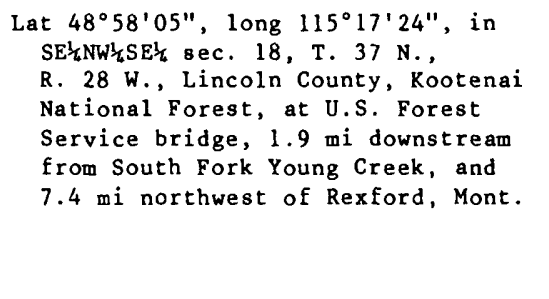 & $\begin{array}{l}04-15-82 \\
05-14-82 \\
06-15-82 \\
07-15-82 \\
08-16-82 \\
09-14-82 \\
10-15-82 \\
11-16-82 \\
12-15-82 \\
01-19-83\end{array}$ & $\begin{array}{c}7.78 \\
53.8 \\
67.2 \\
23.6 \\
15.4 \\
9.01 \\
7.58 \\
6.50 \\
5.37 \\
4.90\end{array}$ \\
\hline 2 & $\begin{array}{l}\text { Young } \\
\text { Creek } \\
\text { at } \\
\text { mouth }\end{array}$ & $\begin{array}{l}\text { Kootenai } \\
\text { River }\end{array}$ & 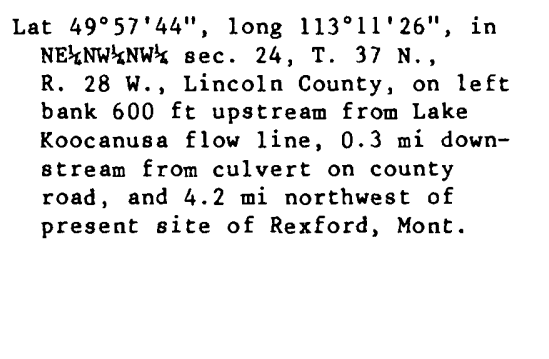 & $\begin{array}{l}03-16-82 \\
04-15-82 \\
05-14-82 \\
06-15-82 \\
07-15-82 \\
08-16-82 \\
09-14-82 \\
10-15-82 \\
11-16-82 \\
12-15-82 \\
01-19-83 \\
02-16-83\end{array}$ & $\begin{array}{l}6.70 \\
10.1 \\
44.9 \\
78.2 \\
23.5 \\
11.3 \\
6.36 \\
6.34 \\
6.11 \\
7.73 \\
6.23 \\
5.74\end{array}$ \\
\hline 3 & $\begin{array}{l}\text { Cayuse } \\
\text { Creek } \\
(12300400)\end{array}$ & $\begin{array}{l}\text { Swamp } \\
\text { Creek }\end{array}$ & $\begin{array}{l}\text { Lat } 48^{\circ} 36^{\prime} 33^{\prime \prime} \text {, long } 115^{\circ} 01^{\prime} 42^{\prime \prime} \text {, in } \\
\text { SW' SW' } \mathrm{NE}^{\frac{1}{4}} \text { sec. } 24, \mathrm{~T} \text {. } 33 \mathrm{~N} \text {, } \\
\text { R. } 27 \mathrm{~W} \text {, Lincoln County, at cul- } \\
\text { vert on U.S. Forest Service road, } \\
9.8 \mathrm{mi} \text { southwest of Trego, Mont., } \\
\text { at site of crest-8tage station. }\end{array}$ & $\begin{array}{l}03-15-82 \\
04-14-82 \\
05-13-82 \\
06-14-82 \\
07-16-82 \\
08-17-82 \\
09-15-82 \\
10-12-82 \\
11-16-82 \\
02-16-83\end{array}$ & $\begin{array}{c}1.85 \\
10.5 \\
36.0 \\
4.75 \\
3.66 \\
1.09 \\
.89 \\
.58 \\
.58 \\
.92\end{array}$ \\
\hline 4 & $\begin{array}{l}\text { Fortine } \\
\text { Creek } \\
(12300500)\end{array}$ & $\begin{array}{l}\text { Tobacco } \\
\text { River }\end{array}$ & 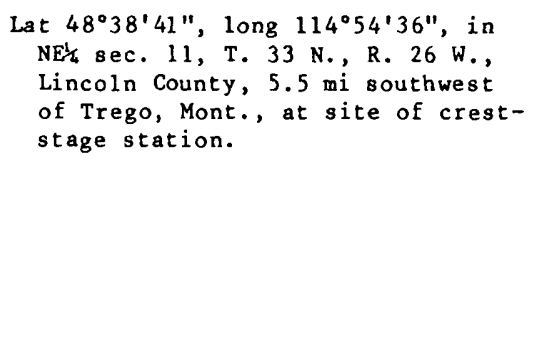 & $\begin{array}{l}03-15-82 \\
04-14-82 \\
05-13-82 \\
06-14-82 \\
07-16-82 \\
08-17-82 \\
09-15-82 \\
10-12-82 \\
11-16-82 \\
12-16-82 \\
01-19-83 \\
02-16-83\end{array}$ & $\begin{array}{c}68.3 \\
182 \\
376 \\
108 \\
58.7 \\
13.0 \\
9.48 \\
9.85 \\
10.2 \\
12.2 \\
23.8 \\
21.6\end{array}$ \\
\hline 5 & $\begin{array}{l}\text { Deep } \\
\text { Creek } \\
(12300800)\end{array}$ & $\begin{array}{l}\text { Fortine } \\
\text { Creek }\end{array}$ & $\begin{array}{l}\text { Lat } 48^{\circ} 45^{\prime} 41^{\prime \prime}, \text { long } 114^{\circ} 52^{\prime} 32^{\prime \prime} \text {, in } \\
\text { SW' sec. } 30, \mathrm{~T} .35 \mathrm{~N} \text {., R. } 25^{\mathrm{W}} \mathrm{W} \text {, } \\
\text { Lincoln Count, at culvert on } \\
\text { county road, } 1.2 \mathrm{mi} \text { east of For- } \\
\text { tine, Mont., at site of crest-stage } \\
\text { station. }\end{array}$ & $\begin{array}{l}03-15-82 \\
04-14-82 \\
05-13-82 \\
06-14-82 \\
06-15-82 \\
07-16-82 \\
08-17-82 \\
09-15-82 \\
10-12-82 \\
11-16-82 \\
12-16-82 \\
01-19-83 \\
02-16-83\end{array}$ & $\begin{array}{c}2.31 \\
1.89 \\
8.16 \\
101 \\
99.7 \\
39.4 \\
10.8 \\
5.63 \\
6.06 \\
3.08 \\
3.46 \\
2.39 \\
2.19\end{array}$ \\
\hline 7 & $\begin{array}{l}\text { Sullivan } \\
\text { Creek }\end{array}$ & $\begin{array}{l}\text { Kootenai } \\
\text { River }\end{array}$ & 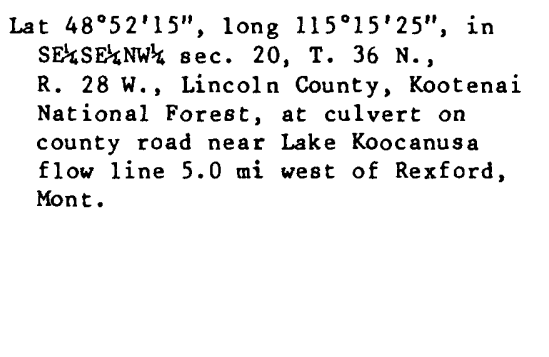 & $\begin{array}{l}03-16-82 \\
04-15-82 \\
05-14-82 \\
06-15-82 \\
07-15-82 \\
08-16-82 \\
09-14-82 \\
10-15-82 \\
11-15-82 \\
12-15-82 \\
01-18-83 \\
02-15-83\end{array}$ & $\begin{array}{l}7.18 \\
14.6 \\
36.8 \\
24.1 \\
24.3 \\
8.38 \\
5.56 \\
4.09 \\
3.64 \\
2.17 \\
3.45 \\
3.80\end{array}$ \\
\hline
\end{tabular}


Table 1. Streamflow measurements and site descriptions-Continued

\begin{tabular}{|c|c|c|c|c|c|}
\hline $\begin{array}{l}\text { Site } \\
\text { No. }\end{array}$ & $\begin{array}{l}\text { St ream } \\
\text { name }\end{array}$ & $\begin{array}{l}\text { Tribu- } \\
\text { tary } \\
\text { to }\end{array}$ & Location & Date & $\begin{array}{l}\text { Dis- } \\
\text { charge } \\
(\mathrm{ft} 3 / \mathrm{s})\end{array}$ \\
\hline \multicolumn{6}{|c|}{ Kootenai River Basin--Continued } \\
\hline 8 & $\begin{array}{l}\text { Boulder } \\
\text { Creek }\end{array}$ & $\begin{array}{l}\text { Kootenai } \\
\text { River }\end{array}$ & $\begin{array}{l}\text { Lat } 48^{\circ} 49^{\prime} 18^{\prime \prime} \text {, long } 115^{\circ} 17^{\prime} 30^{\prime \prime} \text {, in } \\
\text { NW'sSW'4SE sec. 1, T. } 35 \mathrm{~N} \text {., } \\
\text { R. } 29 \text { W., Lincoln County, Kootenai } \\
\text { National Forest, at culvert near } \\
\text { mouth on county road } 8.0 \mathrm{mi} \text { south- } \\
\text { east of Rexford, Mont. }\end{array}$ & $\begin{array}{l}03-16-82 \\
04-15-82 \\
05-14-82 \\
06-14-82 \\
07-14-82 \\
08-16-82 \\
09-14-82 \\
10-15-82 \\
11-15-82 \\
12-15-82 \\
01-18-83 \\
02-15-83\end{array}$ & $\begin{array}{l}9.46 \\
20.7 \\
77.7 \\
86.0 \\
31.1 \\
10.1 \\
5.69 \\
6.49 \\
3.58 \\
5.02 \\
6.90 \\
5.11\end{array}$ \\
\hline 9 & $\begin{array}{l}\text { Big } \\
\text { Creek } \\
\text { near } \\
\text { Rexford } \\
(12301810)\end{array}$ & $\begin{array}{l}\text { Kootenai } \\
\text { River }\end{array}$ & $\begin{array}{l}\text { Lat } 48^{\circ} 44^{\prime} 53^{\prime \prime} \text {, long } 115^{\circ} 21^{\prime} 09^{\prime \prime} \text {, in } \\
\text { SExSW'SE' sec. } 33 \text {, T. } 35 \text { N. , } \\
\text { R. } 29 \text { W., Lincoln County, Kootenai } \\
\text { National Forest, on left bank } \\
500 \mathrm{ft} \text { downstream from highway } \\
\text { bridge, } 0.3 \mathrm{mi} \text { upstream from Lake } \\
\text { Koocanusa flow line, and } 13.6 \mathrm{mi} \\
\text { southwest of present site of } \\
\text { Rexford, Mont., at site of former } \\
\text { gaging station. }\end{array}$ & $\begin{array}{l}03-16-82 \\
04-15-82 \\
05-13-82 \\
06-14-82 \\
07-14-82 \\
08-16-82 \\
09-14-82 \\
10-15-82 \\
11-15-82 \\
12-15-82 \\
01-18-83 \\
02-15-83\end{array}$ & $\begin{array}{c}67.2 \\
162 \\
-- \\
-- \\
154 \\
30.4 \\
21.2 \\
18.7 \\
7.14 \\
10 \\
35.0 \\
38.4\end{array}$ \\
\hline 10 & $\begin{array}{l}\text { Bristow } \\
\text { Creek }\end{array}$ & $\begin{array}{l}\text { Kootenai } \\
\text { River }\end{array}$ & $\begin{array}{l}\text { Lat } 48^{\circ} 32^{\prime} 40^{\prime \prime}, \text { long } 115^{\circ} 17^{\prime} 20^{\prime \prime} \text {, in } \\
\text { SEx sec. 10, T. } 32 \mathrm{~N} \text {, R. } 29^{\prime} \mathrm{W} . \text {, } \\
\text { Lincoln County, at bridge on county } \\
\text { road west of Lake Koocanusa, } 9.0 \mathrm{mi} \\
\text { upstream from the dam, and } 12.0 \mathrm{mi} \\
\text { northwest of Libby, Mont. }\end{array}$ & $\begin{array}{l}09-16-74 \\
05-15-75 \\
05-28-75 \\
06-04-75 \\
09-30-75\end{array}$ & $\begin{array}{rl}229 & .35 \\
52.2 \\
67.8 \\
.32\end{array}$ \\
\hline 15 & $\begin{array}{l}\text { Parmenter } \\
\text { Creek }\end{array}$ & $\begin{array}{l}\text { Kootenai } \\
\text { River }\end{array}$ & 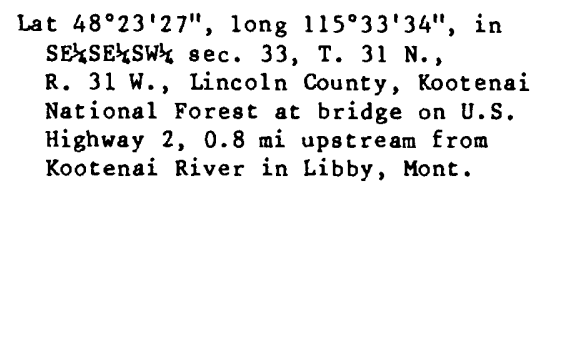 & $\begin{array}{l}03-16-82 \\
04-15-82 \\
05-20-82 \\
06-15-82 \\
07-14-82 \\
08-19-82 \\
09-14-82 \\
10-13-82 \\
11-17-82 \\
12-13-82 \\
01-20-83 \\
02-17-83\end{array}$ & $\begin{array}{c}25.2 \\
43.3 \\
107 \\
187 \\
46.8 \\
1.82 \\
1.22 \\
.31 \\
1.39 \\
0 \\
1.93 \\
1.67\end{array}$ \\
\hline 16 & $\begin{array}{l}\text { Cedar } \\
\text { Creek }\end{array}$ & $\begin{array}{l}\text { Kootenai } \\
\text { River }\end{array}$ & $\begin{array}{l}\text { Lat } 48^{\circ} 25^{\prime} 50^{\prime \prime} \text {, long } 115^{\circ} 37^{\prime} 41^{\prime \prime} \text {, in } \\
\text { NW/SE'/SE' sec. } 24, T .31 \mathrm{~N} \text {, , } \\
\text { R. } 32 \text { W., Lincoln County, Kootenai } \\
\text { National Forest, at bridge on U.S. } \\
\text { Highway } 2,0.1 \text { mi upstream from } \\
\text { Kootenai River, and } 5.0 \mathrm{mi} \text { northwest } \\
\text { of Libby, Mont. }\end{array}$ & $\begin{array}{l}03-16-82 \\
04-15-82 \\
05-20-82 \\
06-15-82 \\
07-14-82 \\
08-19-82 \\
09-13-82 \\
10-13-82 \\
11-17-82 \\
12-13-82 \\
01-20-83 \\
02-17-83\end{array}$ & $\begin{array}{c}34.4 \\
41.4 \\
105 \\
137 \\
27.0 \\
11.8 \\
7.83 \\
7.78 \\
8.51 \\
7.09 \\
8.93 \\
6.55\end{array}$ \\
\hline 17 & $\begin{array}{l}\text { Quartz } \\
\text { Creek }\end{array}$ & $\begin{array}{l}\text { Kootenai } \\
\text { River }\end{array}$ & $\begin{array}{l}\text { Lat } 48^{\circ} 26^{\prime} 21^{\prime \prime} \text {, long } 115^{\circ} 38^{\prime} 08^{\prime \prime} \text {, in } \\
\text { SW/4NE'/NW'/ sec. } 24, \mathrm{~T} .31 \mathrm{~N} \text {., } \\
\text { R. } 32 \mathrm{~W} \text {., Lincoln County, Kootenai } \\
\text { Nationa } 1 \text { Forest, at county road } \\
\text { bridge, } 0.1 \text { mi upstream from mouth, } \\
\text { and } 5.0 \mathrm{mi} \text { northwest of Libby, Mont. }\end{array}$ & $\begin{array}{l}03-16-82 \\
04-14-82 \\
05-20-82 \\
06-15-82 \\
07-14-82 \\
08-19-82 \\
09-13-82 \\
10-13-82 \\
11-15-82 \\
12-13-82 \\
01-19-83 \\
02-15-83\end{array}$ & $\begin{array}{l}90.7 \\
156 \\
330 \\
278 \\
61.0 \\
31.1 \\
32.8 \\
21.2 \\
18.7 \\
31.9 \\
44.4 \\
38.1\end{array}$ \\
\hline
\end{tabular}


Table 1. Streamflow measurements and site descriptions-Continued

\begin{tabular}{|c|c|c|c|c|c|}
\hline $\begin{array}{l}\text { Site } \\
\text { No. }\end{array}$ & $\begin{array}{c}\text { St ream } \\
\text { name }\end{array}$ & $\begin{array}{l}\text { Tribu- } \\
\text { tary } \\
\text { to }\end{array}$ & Location & Date & $\begin{array}{l}\text { Dis- } \\
\text { charge } \\
\left(\mathrm{ft}^{3} / \mathrm{s}\right)\end{array}$ \\
\hline
\end{tabular}

Kootenai River Basin--Continued

18 Camp (12303440)
Lake Creek Lat $48^{\circ} 18^{\prime} 46^{\prime \prime}$, long $115^{\circ} 50^{\prime} 35^{\prime \prime}$, in SW'SEl/ sec. 32 , T. 30 N., R. 33 W., Lincoln County, at bridge on U.S. Forest Service road, $0.8 \mathrm{mi}$ east of Highway $202,12.6 \mathrm{mi}$ south of Troy, Mont., at site of creststage station.

$\begin{array}{cc}03-15-82 & 15.1 \\ 04-14-82 & 20.0 \\ 05-19-82 & 82.0 \\ 06-14-82 & 143 \\ 07-12-82 & 47.2 \\ 08-17-82 & 6.41 \\ 09-13-82 & 4.16 \\ 10-13-82 & 4.78 \\ 11-17-82 & 4.53 \\ 12-15-82 & 4.63 \\ 01-19-83 & 6.20 \\ 02-17-83 & 5.27\end{array}$

19 Ruby Kootenai Creek River
Lat $48^{\circ} 31^{\prime} 07^{\prime \prime}$, long $115^{\circ} 57^{\prime} 00^{\prime \prime}$, NW/ $\frac{1}{4} S^{\frac{1}{4}} S^{\frac{1}{4}}$ sec. 21, T. 32 N., R. 34 W., Lincoln County, Kootenai National Forest, at bridge on county road, $0.3 \mathrm{mi}$ upstream from Kootenai River, and $5.0 \mathrm{mi}$ northwest of Troy, Mont.
03-15-82

$04-14-82$ 05-19-82 06-14-82

$07-13-82$ $08-18-82$ $09-14-82$

$10-13-82$

$11-17-82$

$12-15-82$

$01-19-83$

02-17-83

03-15-82

04-13-82 126

05-20-82 219

06-14-82 83.1

$07-13-82-27.2$

08-18-82 4.84

09-14-82 4.13

$10-14-82 \quad 2.97$

$11-16-82 \quad 5.10$

$12-14-82 \quad 11.8$

$01-18-83 \quad 29.7$

02-16-83 23.0

03-15-82 64.1

04-13-82 178

05-20-82 222

06-14-82 83.6

07-13-82 26.0

08-18-82 6.29

09-14-82 3.94

10-14-82 3.16

$11-16-82 \quad 6.90$

12-14-82 13.5

$01-18-83 \quad 34.0$

$02-16-83 \quad 30.0$

03-15-82 3.92

04-13-82 10.9

05-20-82 9.59

06-14-82 2.43

07-13-82 .61

08-18-82 0

09-14-82 0

10-14-82

1 1-16-82

12-13-82

$01-18-83$

02-16-83

03-15-82

04-13-82 99.1

05-19-82 398

06-14-82 592

07-13-82 81.5

08-18-82 19.6

$09-14-82 \quad 17.0$

10-14-82 16.4

$11-16-82 \quad 17.2$

12-14-82 31.5

01-18-83 31.0

02-16-83 28.3 
Table 1. Streamflow measurements and site descriptions-Continued

\begin{tabular}{|c|c|c|c|c|c|}
\hline $\begin{array}{l}\text { Site } \\
\text { No. }\end{array}$ & $\begin{array}{l}\text { Stream } \\
\text { name }\end{array}$ & $\begin{array}{l}\text { Tribu- } \\
\text { tary } \\
\text { to }\end{array}$ & Location & Date & $\begin{array}{l}\text { Dis- } \\
\text { charge } \\
(f t 3 / s)\end{array}$ \\
\hline \multicolumn{6}{|c|}{ Kootenai River Basin--Continued } \\
\hline 24 & $\begin{array}{l}\text { He11- } \\
\text { roar- } \\
\text { ing } \\
\text { Creek } \\
\text { at } \\
\text { Forest } \\
\text { Service } \\
\text { bridge }\end{array}$ & $\begin{array}{l}\text { Yaak } \\
\text { River }\end{array}$ & $\begin{array}{l}\text { Lat } 48^{\circ} 50^{\prime} 07^{\prime \prime}, \text { long } 115^{\circ} 58^{\prime} 05^{\prime \prime}, \\
\text { landline description unsurveyed, } \\
\text { Lincoln County, Kootenai National } \\
\text { Forest, at U.S. Forest Service } \\
\text { bridge, } 4.0 \text { mi upstream from Yaak } \\
\text { River, and } 11.5 \text { mi west of } \\
\text { Yaak, Mont. }\end{array}$ & $\begin{array}{l}05-19-82 \\
06-15-82 \\
07-13-82 \\
08-18-82 \\
09-14-82 \\
10-14-82 \\
11-16-82\end{array}$ & $\begin{array}{l}189 \\
172 \\
15.3 \\
4.78 \\
4.38 \\
4.17 \\
5.77\end{array}$ \\
\hline 25 & $\begin{array}{l}\text { He } 11- \\
\text { roaring } \\
\text { Creek } \\
\text { at } \\
\text { mouth }\end{array}$ & $\begin{array}{l}\text { Yaak } \\
\text { River }\end{array}$ & $\begin{array}{l}\text { Lat } 48^{\circ} 47^{\prime} 16^{\prime \prime}, \text { long } 115^{\circ} 55^{\prime} 08^{\prime \prime} \text {, } \\
\text { land } 1 \text { ine description unsurveyed, } \\
\text { Lincoln County, Kootenai National } \\
\text { Forest, at bridge on FAS 508, } 0.1 \\
\text { mi upstream from Yaak River, and } \\
10.1 \text { mi southwest of Yaak, Mont. }\end{array}$ & $\begin{array}{l}03-15-82 \\
04-13-82 \\
05-19-82 \\
06-15-82 \\
07-13-82 \\
08-18-82 \\
09-14-82 \\
10-14-82 \\
11-16-82 \\
12-14-82 \\
01-18-83 \\
02-16-83\end{array}$ & $\begin{array}{c}21.8 \\
51.1 \\
185 \\
179 \\
20.3 \\
2.91 \\
3.79 \\
3.96 \\
6.64 \\
11.8 \\
14.7 \\
9.31\end{array}$ \\
\hline 26 & $\begin{array}{l}\text { North } \\
\text { Fork } \\
\text { Meadow } \\
\text { Creek }\end{array}$ & $\begin{array}{l}\text { Yaak } \\
\text { River }\end{array}$ & $\begin{array}{l}\text { Lat } 48^{\circ} 47 \cdot 56^{\prime \prime}, \text { long } 115^{\circ} 56^{\prime} 57^{\prime \prime}, \text { land- } \\
\text { line description unsurveyed, Lincoln } \\
\text { County, Kootenai National Forest, } \\
\text { near switchback in U.S. Forest } \\
\text { Service road, } 1.2 \text { mi upstream from } \\
\text { Meadow Creek, 1.6 mi west of FAS } \\
508 \text {, and } 11.5 \text { mi southwest of Yaak, } \\
\text { Mont. }\end{array}$ & $\begin{array}{l}05-19-82 \\
06-15-82 \\
07-13-82 \\
08-18-82 \\
09-14-82 \\
10-14-82 \\
11-16-82\end{array}$ & $\begin{array}{l}86.7 \\
90.3 \\
12.4 \\
2.62 \\
2.03 \\
1.47 \\
3.49\end{array}$ \\
\hline 27 & $\begin{array}{l}\text { North } \\
\text { Fork } \\
\text { Meadow } \\
\text { Creek } \\
\text { at } \\
\text { mouth }\end{array}$ & $\begin{array}{l}\text { Yaak } \\
\text { River }\end{array}$ & $\begin{array}{l}\text { Lat } 48^{\circ} 47^{\prime} 14^{\prime \prime}, \text { long } 115^{\circ} 56^{\prime} 16^{\prime \prime}, \\
\text { land } 1 \text { ine description unsurveyed, } \\
\text { Lincoln County, Kootenai National } \\
\text { Forest, at U.S. Forest Service } \\
\text { bridge } 0.2 \mathrm{mi} \text { upstream from Meadow } \\
\text { Creek, } 0.8 \mathrm{mi} \text { west of FAS } 508 \text {, and } \\
11.0 \mathrm{mi} \text { southwest of Yaak, Mont. }\end{array}$ & $\begin{array}{l}05-19-82 \\
06-15-82 \\
07-13-82 \\
08-18-82 \\
09-14-82 \\
10-14-82 \\
11-16-82\end{array}$ & $\begin{array}{r}91.8 \\
71.0 \\
10.1 \\
2.53 \\
3.22 \\
2.96 \\
4.28\end{array}$ \\
\hline 28 & $\begin{array}{l}\text { Meadow } \\
\text { Creek }\end{array}$ & $\begin{array}{l}\text { Yaak } \\
\text { River }\end{array}$ & $\begin{array}{l}\text { Lat } 48^{\circ} 47^{\prime} 01^{\prime \prime} \text {, long } 115^{\circ} 55^{\prime} 20^{\prime \prime}, \text { land- } \\
\text { line description unsurveyed, } \\
\text { Lincoln County, Kootenai National } \\
\text { Forest, at bridge on FAS } 508,0.1 \mathrm{mi} \\
\text { upstream from Yaak River, and } 10.5 \\
\text { mi southwest of Yaak, Mont. }\end{array}$ & $\begin{array}{l}03-15-82 \\
04-13-82 \\
05-18-82 \\
06-15-82 \\
07-13-82 \\
08-18-82 \\
09-14-82 \\
10-14-82 \\
11-16-82 \\
12-15-82 \\
01-18-83 \\
02-16-83\end{array}$ & $\begin{array}{c}40.2 \\
74.1 \\
355 \\
186 \\
42.4 \\
7.78 \\
6.46 \\
6.27 \\
10.7 \\
19.4 \\
20.8 \\
18.1\end{array}$ \\
\hline 29 & $\begin{array}{l}\text { Red } \\
\text { Top } \\
\text { Creek }\end{array}$ & $\begin{array}{l}\text { Yaak } \\
\text { River }\end{array}$ & $\begin{array}{l}\text { Lat } 48^{\circ} 45^{\prime} 42^{\prime \prime} \text {, long } 115^{\circ} 55^{\prime} 58^{\prime \prime} \text {, land- } \\
\text { line description unsurveyed, Lincoln } \\
\text { County, Kootenai National Forest, at } \\
\text { Red Top Creek Campground, } 0.2 \mathrm{mi} \text { up- } \\
\text { stream from Yaak River, and } 10.7 \mathrm{mi} \\
\text { west of Yaak, Mont. }\end{array}$ & $\begin{array}{l}03-82 \\
04-82 \\
05-82 \\
06-82 \\
07-82 \\
08-82 \\
09-82 \\
10-82 \\
11-82\end{array}$ & $\begin{array}{c}19.1{ }^{1} \\
27.8 \\
105 \\
44.6 \\
14.0 \\
6.00 \\
3.70 \\
4.74 \\
15.8\end{array}$ \\
\hline 30 & $\begin{array}{l}\text { Cyclone } \\
\text { Creek } \\
(12304300)\end{array}$ & $\begin{array}{l}\text { Yaak } \\
\text { River }\end{array}$ & 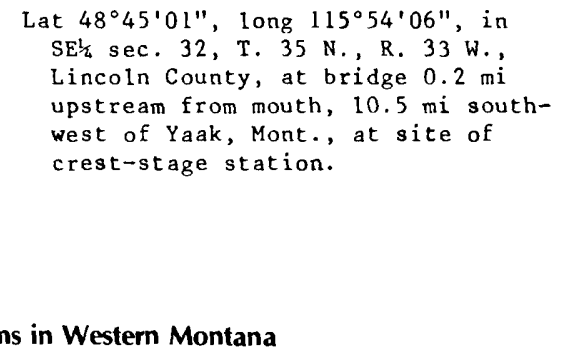 & $\begin{array}{l}03-16-82 \\
04-14-82 \\
05-18-82 \\
06-15-82 \\
07-13-82 \\
08-18-82 \\
09-14-82 \\
10-14-82 \\
11-16-82 \\
12-15-82 \\
01-18-83 \\
02-16-83\end{array}$ & $\begin{array}{r}11.9 \\
25.9 \\
92.9 \\
48.0 \\
8.94 \\
4.05 \\
1.33 \\
3.04 \\
3.25 \\
5.24 \\
6.71 \\
6.85\end{array}$ \\
\hline
\end{tabular}


Table 1. Streamflow measurements and site descriptions-Continued

\begin{tabular}{|c|c|c|c|c|c|}
\hline $\begin{array}{l}\text { Site } \\
\text { No. }\end{array}$ & $\begin{array}{l}\text { St ream } \\
\text { name }\end{array}$ & $\begin{array}{l}\text { Tribu- } \\
\text { tary } \\
\text { to }\end{array}$ & Location & Date & $\begin{array}{l}\text { Dis- } \\
\text { charge } \\
(\mathrm{ft} 3 / \mathrm{s})\end{array}$ \\
\hline & & & Ootenai River Basin--Continued & & \\
\hline \multirow[t]{2}{*}{31} & $\begin{array}{l}\text { Fourth } \\
\text { of } \\
\text { July } \\
\text { Creek } \\
(12304400)\end{array}$ & $\begin{array}{l}\text { Yaak } \\
\text { River }\end{array}$ & $\begin{array}{l}\text { Lat } 48^{\circ} 42^{\prime} 04^{\prime \prime}, \text { long } 115^{\circ} 52^{\prime} 04^{\prime \prime} \text {, in } \\
\text { NW' sec. } 22 \text {, T. } 34 \mathrm{~N} \text {. , R. } 33 \mathrm{~W} \text {., } \\
\text { Lincoln County, at bridge } 500 \mathrm{ft} \\
\text { upstream from mouth, } 12.0 \mathrm{mi} \text { south- } \\
\text { west of Yaak, Mont., at site of } \\
\text { crest-8tage station. }\end{array}$ & $\begin{array}{l}03-16-82 \\
04-14-82 \\
05-18-82 \\
06-15-82 \\
07-13-82 \\
08-18-82 \\
09-14-82 \\
10-14-82 \\
11-16-82 \\
12-15-82 \\
01-18-83 \\
02-16-83\end{array}$ & $\begin{array}{c}13.1 \\
41.8 \\
148 \\
39.6 \\
10.5 \\
2.89 \\
2.40 \\
2.55 \\
2.92 \\
3.61 \\
8.16 \\
9.53\end{array}$ \\
\hline & & & Pend Oreille River Basin & & \\
\hline 40 & $\begin{array}{l}\text { Deer } \\
\text { Creek } \\
(12339300)\end{array}$ & $\begin{array}{l}\text { Clear- } \\
\text { water } \\
\text { River }\end{array}$ & 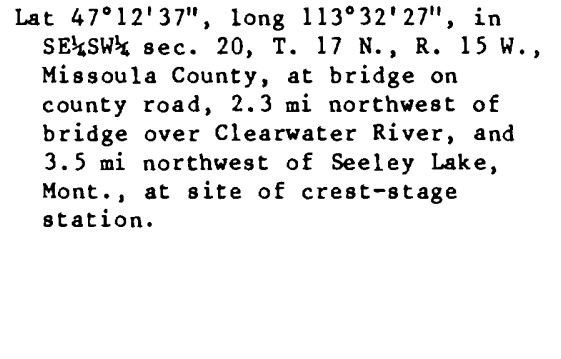 & $\begin{array}{l}03-15-82 \\
04-19-82 \\
05-20-82 \\
06-14-82 \\
07-13-82 \\
08-17-82 \\
09-16-82 \\
10-18-82 \\
11-15-82 \\
12-13-82 \\
01-17-83 \\
02-15-83\end{array}$ & $\begin{array}{c}11.5 \\
36.8 \\
139 \\
110 \\
27.0 \\
5.00 \\
3.49 \\
4.53 \\
3.25 \\
3.01 \\
3.72 \\
3.65\end{array}$ \\
\hline 41 & $\begin{array}{l}\text { Seeley } \\
\text { Creek }\end{array}$ & $\begin{array}{l}\text { Clear- } \\
\text { water } \\
\text { River }\end{array}$ & $\begin{array}{l}\text { Lat } 47^{\circ} 11^{\prime} 00^{\prime \prime} \text {, long } 113^{\circ} 28^{\prime} 52^{\prime \prime} \text {, in } \\
\text { SE }{ }^{\prime} \text { sec. } 35, \mathrm{~T} \text {. } 17 \mathrm{~N} \text {, , R. } 15 \mathrm{~W} ., \\
\text { Missoula County, at culvert on } \\
\text { county road, } 0.2 \mathrm{mi} \text { east of U.S. } \\
\text { Highway } 83 \text {, at Seeley Lake, Mont. }\end{array}$ & $\begin{array}{l}09-12-74 \\
05-14-75 \\
06-12-75\end{array}$ & $\begin{array}{l}25.8 \\
24.6 \\
4.29\end{array}$ \\
\hline 42 & $\begin{array}{l}\text { West } \\
\text { Twin } \\
\text { Creek } \\
(12339900)\end{array}$ & $\begin{array}{l}\text { Clark } \\
\text { Fork }\end{array}$ & $\begin{array}{l}\text { Lat } 46^{\circ} 54^{\prime} 44^{\prime \prime}, \text { long } 113^{\circ} 42^{\prime} 50^{\prime \prime} \text {, in } \\
\text { SWh sec. } 2 \text {, T. } 13 \mathrm{~N} . \text {, R. } 17 \mathrm{~W} \text {. , } \\
\text { Missoula County, at bridge on State } \\
\text { Highway } 200,8.0 \mathrm{mi} \text { east of Bonner, } \\
\text { Mont., at site of crest-stage } \\
\text { station. }\end{array}$ & $\begin{array}{l}03-17-82 \\
04-14-82 \\
05-20-82 \\
06-17-82 \\
07-15-82 \\
08-19-82 \\
09-18-82 \\
10-21-82 \\
11-18-82 \\
12-17-82 \\
01-20-83 \\
02-17-83\end{array}$ & $\begin{array}{c}9.47 \\
34.6 \\
59.3 \\
68.0 \\
14.9 \\
4.30 \\
3.52 \\
3.42 \\
2.31 \\
2.38 \\
4.42 \\
3.03\end{array}$ \\
\hline 44 & $\begin{array}{l}\text { Marshal1 } \\
\text { Creek } \\
(12340200)\end{array}$ & $\begin{array}{l}\text { Clark } \\
\text { Fork }\end{array}$ & $\begin{array}{l}\text { Lat } 46^{\circ} 53^{\prime} 15^{\prime \prime}, \text { long } 113^{\circ} 55^{\prime} 27^{\prime \prime} \text {, in } \\
\text { NW/ sec. 18, T. 13 N., R. } 18 \mathrm{~W} ., \\
\text { Missoula County, at culvert on } \\
\text { U.S. Highway } 10,3.0 \text { mi east of } \\
\text { Missoula, Mont., at site of former } \\
\text { crest-8tage station. }\end{array}$ & $\begin{array}{l}03-17-82 \\
04-14-82 \\
05-20-82 \\
06-17-82 \\
07-15-82 \\
08-19-82 \\
09-18-82 \\
10-21-82 \\
11-18-82 \\
12-16-82 \\
01-20-83 \\
02-17-83\end{array}$ & $\begin{array}{c}3.29 \\
6.87 \\
13.8 \\
3.00 \\
2.52 \\
1.00 \\
1.08 \\
2.09 \\
1.39 \\
1.57 \\
1.42 \\
1.88\end{array}$ \\
\hline
\end{tabular}


Table 1. Streamflow measurements and site descriptions-Continued

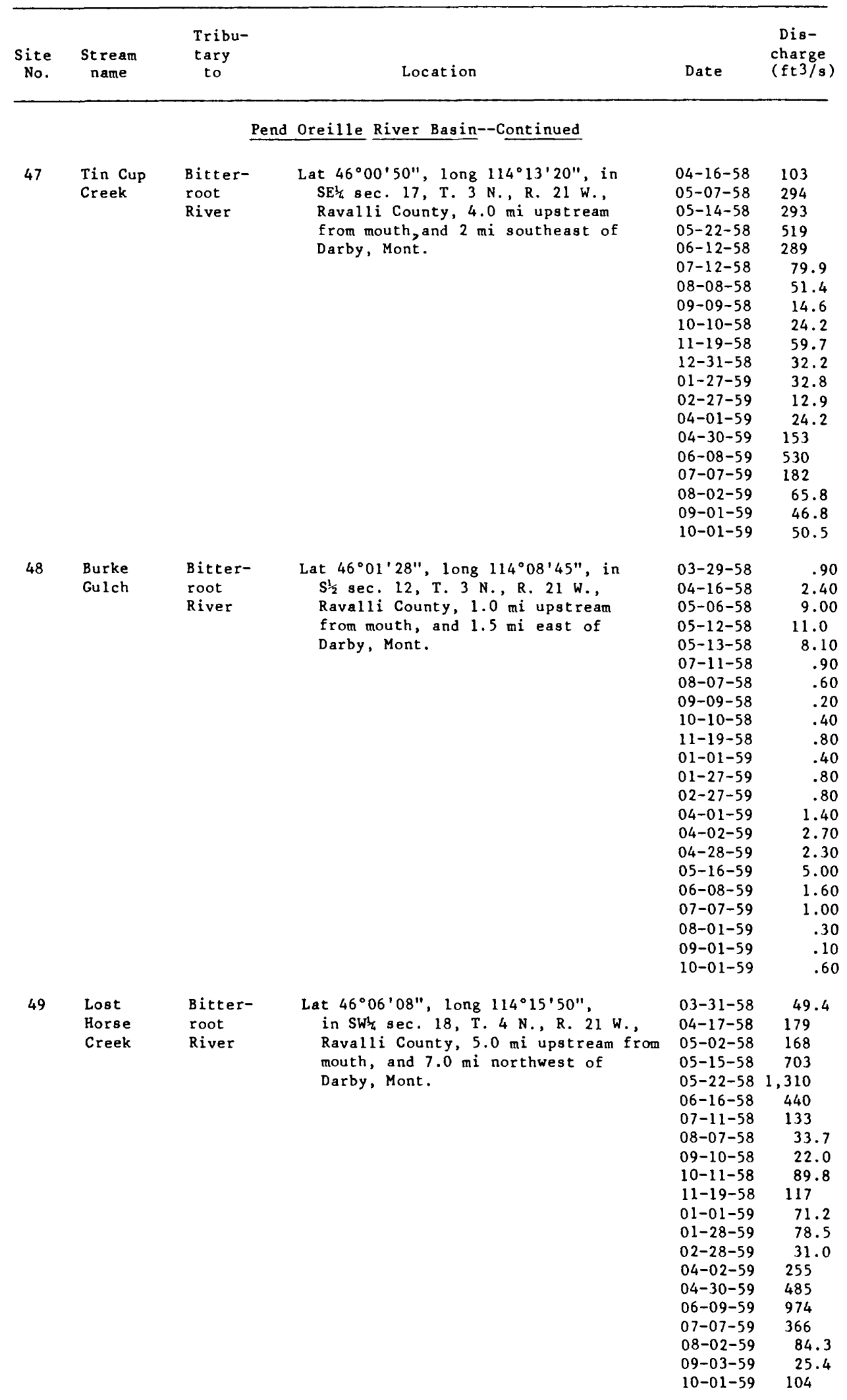


Table 1. Streamflow measurements and site descriptions-Continued

\begin{tabular}{|c|c|c|c|c|c|}
\hline $\begin{array}{c}\text { Site } \\
\text { No. }\end{array}$ & $\begin{array}{l}\text { Stream } \\
\text { name }\end{array}$ & $\begin{array}{l}\text { Tribu- } \\
\text { tary } \\
\text { to }\end{array}$ & Location & Date & $\begin{array}{l}\text { Dis- } \\
\text { charge } \\
(\mathrm{ft} 3 / \mathrm{s})\end{array}$ \\
\hline & & & d Oreille River Basin--Continued & & \\
\hline 50 & $\begin{array}{l}\text { Camas } \\
\text { Creek }\end{array}$ & $\begin{array}{l}\text { Bitter- } \\
\text { root } \\
\text { River }\end{array}$ & $\begin{array}{l}\text { Lat } 46^{\circ} 08^{\prime} 42^{\prime \prime}, \text { long } 14^{\circ} 12^{\prime} 58^{\prime \prime} \text {, in } \\
\text { SW' sec. } 34, \mathrm{~T} .5 \mathrm{~N} . \mathrm{R} .21 \mathrm{~W} \text {, } \\
\text { Ravalli County, } 8.0 \mathrm{mi} \text { southwest of } \\
\text { Hamilton, Mont. }\end{array}$ & $\begin{array}{l}03-31-58 \\
04-17-58 \\
05-07-58 \\
05-15-58 \\
05-20-58 \\
05-25-58 \\
06-12-58 \\
07-12-58 \\
08-08-58 \\
09-10-58 \\
10-11-58 \\
11-21-58 \\
01-01-59 \\
01-28-59 \\
02-28-59 \\
04-02-59 \\
04-30-59 \\
06-07-59 \\
06-09-59 \\
07-09-59 \\
08-02-59 \\
09-03-59 \\
10-02-59\end{array}$ & $\begin{array}{c}1.70 \\
6.40 \\
38.9 \\
44.4 \\
240 \\
103 \\
40.8 \\
10.2 \\
2.50 \\
1.10 \\
1.50 \\
5.80 \\
2.20 \\
1.80 \\
.90 \\
18.6 \\
16.2 \\
190 \\
56.6 \\
20.0 \\
-- \\
-- \\
3.90\end{array}$ \\
\hline 51 & $\begin{array}{l}\text { Sleeping } \\
\text { Child } \\
\text { Creek }\end{array}$ & $\begin{array}{l}\text { Bitter- } \\
\text { root } \\
\text { River }\end{array}$ & $\begin{array}{l}\text { Lat } 46^{\circ} 08^{\prime} 34^{\prime \prime}, \text { long } 114^{\circ} 05^{\prime} 02^{\prime \prime} \text {, in } \\
\text { SEs sec. } 34, \text { T. } 5 \mathrm{~N} . \text {, R. } 20 \mathrm{~W} \text {., } \\
\text { Ravalli County, } 5.0 \mathrm{mi} \text { upstream } \\
\text { from mouth, and } 8.5 \mathrm{mi} \text { southeast } \\
\text { of Hamilton, Mont. }\end{array}$ & $\begin{array}{l}03-30-58 \\
04-18-58 \\
05-02-58 \\
05-07-58 \\
05-13-58 \\
05-25-58 \\
06-14-58 \\
06-14-58 \\
06-19-58 \\
07-13-58 \\
08-09-58 \\
09-10-58 \\
10-11-58 \\
11-18-58 \\
01-01-59 \\
01-29-59 \\
03-01-59 \\
03-31-59 \\
05-01-59 \\
06-07-59 \\
07-06-59 \\
08-02-59 \\
09-03-59 \\
10-02-59\end{array}$ & $\begin{array}{c}14.2 \\
34.2 \\
44.0 \\
158 \\
222 \\
392 \\
161 \\
152 \\
111 \\
45.1 \\
20.5 \\
12.4 \\
15.2 \\
11.1 \\
9.40 \\
13.4 \\
14.0 \\
15.4 \\
70.3 \\
339 \\
70.2 \\
20.7 \\
11.8 \\
11.8\end{array}$ \\
\hline 52 & $\begin{array}{l}\text { Little } \\
\text { Sleep- } \\
\text { ing } \\
\text { Child } \\
\text { Creek }\end{array}$ & $\begin{array}{l}\text { Bitter- } \\
\text { root } \\
\text { River }\end{array}$ & $\begin{array}{l}\text { Lat } 46^{\circ} 06^{\prime} 25^{\prime \prime}, \text { long } 114^{\circ} 06^{\prime} 08^{\prime \prime} \text {, in } \\
\text { SE } \frac{1}{4} \text { sec. } 8, T .4 \mathrm{~N} ., \mathrm{R} .20 \mathrm{~W} . \text {, } \\
\text { Raval1i County, } 3.5^{\mathrm{mi}} \text { upstream } \\
\text { from mouth, and } 10.0 \mathrm{mi} \text { southeast } \\
\text { of Hamilton, Mont. }\end{array}$ & $\begin{array}{l}03-30-58 \\
04-18-58 \\
05-07-58 \\
05-13-58 \\
05-25-58 \\
06-14-58 \\
07-13-58 \\
08-09-58 \\
09-10-58 \\
10-11-58 \\
11-18-58 \\
01-01-59 \\
01-29-59 \\
03-01-59 \\
03-31-59 \\
05-01-59 \\
06-07-59 \\
07-06-59 \\
08-02-59 \\
09-03-59 \\
10-02-59\end{array}$ & $\begin{array}{c}2.00 \\
5.90 \\
23.7 \\
22.1 \\
12.8 \\
6.60 \\
2.10 \\
.70 \\
.60 \\
.80 \\
.90 \\
1.00 \\
1.20 \\
1.50 \\
1.80 \\
7.40 \\
7.90 \\
1.40 \\
.70 \\
.60 \\
1.00\end{array}$ \\
\hline
\end{tabular}


Table 1. Streamflow measurements and site descriptions-Continued

\begin{tabular}{|c|c|c|c|c|c|}
\hline $\begin{array}{l}\text { Site } \\
\text { No. }\end{array}$ & $\begin{array}{c}\text { Stream } \\
\text { name }\end{array}$ & $\begin{array}{l}\text { Tribu- } \\
\text { tary } \\
\text { to }\end{array}$ & Location & Date & $\begin{array}{c}\text { Dis- } \\
\text { charge } \\
(\mathrm{ft} 3 / \mathrm{s})\end{array}$ \\
\hline \multicolumn{6}{|c|}{ Pend Oreille River Basin--Continued } \\
\hline 53 & $\begin{array}{l}\text { Roaring } \\
\text { Lion } \\
\text { Creek }\end{array}$ & $\begin{array}{l}\text { Bitter- } \\
\text { root } \\
\text { River }\end{array}$ & $\begin{array}{l}\text { Lat } 46^{\circ} 11^{\prime} 35^{\prime \prime}, \text { long } 114^{\circ} 13^{\prime} 11^{\prime \prime} \text {, in } \\
\text { NWh sec. } 16, T .5 \mathrm{~N} ., \mathrm{R} \text {. } 21 \mathrm{~W} \text {., } \\
\text { Raval1i County, } 4.5 \mathrm{mi} \text { upstream } \\
\text { from mouth, and } 5.0 \mathrm{mi} \text { southwest } \\
\text { of Hamilton, Mont. }\end{array}$ & $\begin{array}{l}04-18-58 \\
06-16-58 \\
06-19-58 \\
07-12-58 \\
08-08-58 \\
09-10-58 \\
10-11-58 \\
11-20-58 \\
01-01-59 \\
01-29-59 \\
02-28-59 \\
04-02-59 \\
05-01-59 \\
06-10-59 \\
07-09-59 \\
08-04-59 \\
09-04-59 \\
10-02-59\end{array}$ & $\begin{array}{c}91.7 \\
147 \\
149 \\
47.4 \\
12.9 \\
4.00 \\
33.1 \\
35.4 \\
15.0 \\
15.3 \\
7.60 \\
80.8 \\
193 \\
269 \\
88.5 \\
24.4 \\
7.10 \\
23.6\end{array}$ \\
\hline 54 & $\begin{array}{l}\text { Sawtooth } \\
\text { Creek }\end{array}$ & $\begin{array}{l}\text { Bitter- } \\
\text { root } \\
\text { River }\end{array}$ & $\begin{array}{l}\text { Lat } 46^{\circ} 12^{\prime} 20^{\prime \prime}, \text { long } 114^{\circ} 13^{\prime} 48^{\prime \prime} \text {, in } \\
\text { NWW/4 sec. } 9, \mathrm{~T} \text {. } 5 \mathrm{~N} ., \mathrm{R} \text {. } 21 \mathrm{~W} \text {., } \\
\text { Raval1i County, } 4.0 \mathrm{mi} \text { upstream } \\
\text { from mouth, and } 4.5 \mathrm{mi} \text { southwest } \\
\text { of Hamilton, Mont. }\end{array}$ & $\begin{array}{l}04-04-58 \\
04-17-58 \\
05-02-58 \\
05-15-58 \\
05-23-58 \\
06-16-58 \\
07-12-58 \\
08-08-58 \\
09-11-58 \\
10-12-58 \\
11-20-58 \\
01-02-59 \\
01-29-59 \\
02-28-59 \\
04-03-59 \\
05-01-59 \\
05-01-59 \\
06-09-59 \\
07-09-59 \\
08-04-59 \\
09-04-59 \\
10-02-59\end{array}$ & $\begin{array}{c}17.5 \\
54.9 \\
72.4 \\
206 \\
360 \\
129 \\
36.0 \\
10.8 \\
5.40 \\
27.1 \\
34.4 \\
8.00 \\
19.8 \\
10.1 \\
55.7 \\
192 \\
189 \\
312 \\
71.0 \\
14.8 \\
4.80 \\
18.6\end{array}$ \\
\hline 56 & $\begin{array}{l}\text { Gird } \\
\text { Creek }\end{array}$ & $\begin{array}{l}\text { Bitter- } \\
\text { root } \\
\text { River }\end{array}$ & $\begin{array}{l}\text { Lat } 46^{\circ} 12^{\prime} 18^{\prime \prime}, \text { long } 114^{\circ} 03^{\prime} 32^{\prime \prime} \text {, near } \\
\text { center sec. } 11, \mathrm{~T} .5 \mathrm{~N} \text {. , R. } 20 \mathrm{~W} \text {. , } \\
\text { Ravalli County, } 5.5 \mathrm{mi} \text { southeast of } \\
\text { Hamilton, Mont. }\end{array}$ & $\begin{array}{l}04-01-58 \\
04-19-58 \\
05-08-58 \\
05-13-58 \\
06-19-58 \\
07-10-58 \\
08-10-58 \\
09-11-58 \\
10-12-58 \\
11-17-58 \\
12-30-58 \\
01-29-59 \\
03-01-59 \\
04-01-59 \\
05-04-59 \\
06-07-59 \\
07-10-59 \\
08-03-59 \\
09-03-59 \\
10-04-59 \\
10-04-59\end{array}$ & $\begin{array}{c}5.80 \\
8.50 \\
22.4 \\
36.1 \\
32.6 \\
27.5 \\
15.9 \\
11.8 \\
9.20 \\
6.30 \\
5.90 \\
6.20 \\
5.70 \\
6.90 \\
11.2 \\
44.8 \\
22.1 \\
14.6 \\
9.60 \\
8.60 \\
9.00\end{array}$ \\
\hline
\end{tabular}


Table 1. Streamflow measurements and site descriptions-Continued

\begin{tabular}{|c|c|c|c|c|c|}
\hline $\begin{array}{c}\text { Site } \\
\text { No. }\end{array}$ & $\begin{array}{c}\text { Stream } \\
\text { name }\end{array}$ & $\begin{array}{l}\text { Tribu- } \\
\text { tary } \\
\text { to }\end{array}$ & Location & Date & $\begin{array}{l}\text { Dis- } \\
\text { charge } \\
(f t 3 / s)\end{array}$ \\
\hline \multicolumn{6}{|c|}{ Pend Oreille River Basin--Continued } \\
\hline 58 & $\begin{array}{l}\text { Mi11 } \\
\text { Creek }\end{array}$ & $\begin{array}{l}\text { Bitter- } \\
\text { root } \\
\text { River }\end{array}$ & $\begin{array}{l}\text { Lat } 46^{\circ} 18^{\prime} 41^{\prime \prime}, \text { long } 11^{\circ} 13^{\prime} 36^{\prime \prime} \text {, in } \\
\mathrm{N}^{\frac{1}{2}} \text { sec. } 4 \text {, T. } 6 \mathrm{~N} ., \mathrm{R} \text {. } 21 \mathrm{~W} \text {.; } \\
\text { Ravalli County, } 6.5 \mathrm{mi} \text { upstream } \\
\text { from mouth, and } 6.0 \mathrm{mi} \text { north- } \\
\text { west of Hamilton, Mont. }\end{array}$ & $\begin{array}{l}04-02-58 \\
04-21-58 \\
05-01-58 \\
05-14-58 \\
05-26-58 \\
06-17-58 \\
07-13-58 \\
08-09-58 \\
09-12-58 \\
10-13-58 \\
11-21-58 \\
01-03-59 \\
01-31-59 \\
03-04-59 \\
04-03-59 \\
05-02-59 \\
06-10-59 \\
07-08-59 \\
08-05-59 \\
09-04-59 \\
10-04-59\end{array}$ & $\begin{array}{c}10.1 \\
72.7 \\
39.2 \\
147 \\
342 \\
116 \\
32.4 \\
12.6 \\
3.70 \\
6.60 \\
47.4 \\
8.00 \\
16.4 \\
11.2 \\
48.7 \\
155 \\
206 \\
74.8 \\
19.0 \\
10.7 \\
28.6\end{array}$ \\
\hline 60 & $\begin{array}{l}\text { Sweat } \\
\text { House } \\
\text { Creek }\end{array}$ & $\begin{array}{l}\text { Bitter- } \\
\text { root } \\
\text { River }\end{array}$ & $\begin{array}{l}\text { Lat } 46^{\circ} 24^{\prime} 56^{\prime \prime} \text {, long } 114^{\circ} 13^{\prime} 13^{\prime \prime} \text {, in } \\
\text { SE } \frac{1}{4} \text { sec. } 28, T .8 \mathrm{~N} \text {. R. R. } 21 \mathrm{~W} ., \\
\text { Raval1i County, } 2.0 \mathrm{mi} \text { upstream } \\
\text { from Gash Creek, and } 3.5 \mathrm{mi} \text { west } \\
\text { of Victor, Mont. }\end{array}$ & $\begin{array}{l}04-04-58 \\
04-21-58 \\
05-14-58 \\
05-25-58 \\
07-08-58 \\
08-06-58 \\
09-12-58 \\
10-13-58 \\
11-20-58 \\
01-02-59 \\
02-02-59 \\
03-03-59 \\
04-04-59 \\
04-29-59 \\
06-11-59 \\
07-08-59 \\
08-04-59 \\
09-02-59 \\
10-04-59\end{array}$ & $\begin{array}{c}4.60 \\
25.7 \\
76.8 \\
189 \\
23.4 \\
6.20 \\
2.10 \\
10.6 \\
16.0 \\
4.50 \\
4.90 \\
6.20 \\
27.1 \\
30.7 \\
78.0 \\
36.6 \\
9.80 \\
6.00 \\
12.2\end{array}$ \\
\hline 61 & $\begin{array}{l}\text { Gash } \\
\text { Creek }\end{array}$ & $\begin{array}{l}\text { Bitter- } \\
\text { root } \\
\text { River }\end{array}$ & $\begin{array}{l}\text { Lat } 46^{\circ} 24^{\prime} 20^{\prime \prime}, \text { long } 114^{\circ} 15^{\prime} 21^{\prime \prime} \text {, in } \\
\text { W } \frac{1}{2} \text { sec. } 32, T .8 \mathrm{~N} . \mathrm{R} \text {. } 21 \mathrm{~W} \text {., } \\
\text { Ravalli County, } 0.5 \mathrm{mi} \text { upstream } \\
\text { from South Fork Gash Creek, and } 5.0 \\
\text { mi west of Victor, Mont. }\end{array}$ & $\begin{array}{l}05-14-58 \\
05-21-58 \\
05-25-58 \\
06-17-58 \\
07-08-58 \\
08-06-58 \\
09-12-58 \\
10-13-58 \\
11-20-58 \\
01-02-59 \\
02-01-59 \\
04-02-59 \\
04-29-59 \\
06-05-59 \\
06-11-59 \\
07-08-59 \\
08-04-59 \\
09-02-59 \\
10-04-59\end{array}$ & $\begin{array}{c}15.1 \\
200 \\
99.4 \\
14.0 \\
10.0 \\
3.80 \\
1.60 \\
2.80 \\
3.70 \\
2.30 \\
1.50 \\
5.50 \\
8.10 \\
160 \\
32.8 \\
10.5 \\
5.00 \\
2.00 \\
3.00\end{array}$ \\
\hline
\end{tabular}


Table 1. Streamflow measurements and site descriptions-Continued

\begin{tabular}{|c|c|c|c|c|c|}
\hline $\begin{array}{c}\text { Site } \\
\text { No. }\end{array}$ & $\begin{array}{l}\text { Stream } \\
\text { name }\end{array}$ & $\begin{array}{l}\text { Tribu- } \\
\text { tary } \\
\text { to }\end{array}$ & Location & Date & $\begin{array}{c}\text { Dis- } \\
\text { charge } \\
(\mathrm{ft} 3 / \mathrm{s})\end{array}$ \\
\hline & & & Pend Oreille River Basin--Continued & & \\
\hline 62 & $\begin{array}{l}\text { Big } \\
\text { Creek } \\
\text { near } \\
\text { Victor }\end{array}$ & $\begin{array}{l}\text { Bitter- } \\
\text { root } \\
\text { River }\end{array}$ & $\begin{array}{l}\text { Lat } 46^{\circ} 27^{\prime} 50^{\prime \prime}, \text { long } 114^{\circ} 12^{\prime} 25^{\prime \prime} \text {, near } \\
\text { center sec. } 10, \mathrm{~T} .8 \mathrm{~N} ., \mathrm{R} .21 \mathrm{~W} ., \\
5.0 \mathrm{mi} \text { upstream from mouth, and } \\
4.0 \mathrm{mi} \text { northwest of victor, Mont. }\end{array}$ & $\begin{array}{l}04-04-58 \\
04-23-58 \\
05-15-58 \\
05-26-58 \\
06-18-58 \\
07-09-58 \\
08-06-58 \\
09-13-58 \\
10-14-58 \\
11-21-58 \\
01-03-59 \\
02-02-59 \\
03-04-59 \\
04-04-59 \\
05-02-59 \\
06-10-59 \\
07-08-59 \\
08-05-59 \\
09-05-59 \\
10-04-59\end{array}$ & $\begin{array}{c}25.5 \\
86.7 \\
276 \\
652 \\
219 \\
96.2 \\
51.2 \\
17.8 \\
39.5 \\
96.7 \\
13.6 \\
22.5 \\
24.3 \\
78.8 \\
263 \\
409 \\
186 \\
24.8 \\
53.8 \\
73.7\end{array}$ \\
\hline 65 & $\begin{array}{l}\text { Bass } \\
\text { Creek }\end{array}$ & $\begin{array}{l}\text { Bitter- } \\
\text { root } \\
\text { River }\end{array}$ & $\begin{array}{l}\text { Lat } 46^{\circ} 34^{\prime} 27^{\prime \prime}, \text { long } 114^{\circ} 08^{\prime} 56^{\prime \prime} \text {, in } \\
\text { SW' sec. } 32, \mathrm{~T} .10 \mathrm{~N} ., \mathrm{R} .20 \mathrm{~W} ., \\
\text { Ravalli County, } 3.0 \mathrm{mi} \text { upstream } \\
\text { from mouth, and } 5.0 \mathrm{mi} \text { southwest } \\
\text { of Florence, Mont. }\end{array}$ & $\begin{array}{l}04-03-58 \\
04-23-58 \\
05-01-58 \\
05-15-58 \\
05-26-58 \\
06-18-58 \\
07-08-58 \\
08-05-58 \\
09-13-58 \\
10-15-58 \\
11-21-58 \\
01-04-59 \\
02-02-59 \\
03-05-59 \\
04-05-59 \\
05-03-59 \\
06-11-59 \\
07-10-59 \\
08-01-59 \\
09-11-59 \\
10-07-59\end{array}$ & $\begin{array}{c}6.40 \\
20.2 \\
16.2 \\
81.2 \\
132 \\
41.9 \\
26.3 \\
33.2 \\
23.2 \\
6.40 \\
28.3 \\
3.50 \\
7.60 \\
5.70 \\
24.5 \\
61.4 \\
82.3 \\
53.8 \\
41.9 \\
23.6 \\
27.2\end{array}$ \\
\hline 66 & $\begin{array}{l}\text { Sweeney } \\
\text { Creek }\end{array}$ & $\begin{array}{l}\text { Bitter- } \\
\text { root } \\
\text { River }\end{array}$ & $\begin{array}{l}\text { Lat } 46^{\circ} 36^{\prime} 30^{\prime \prime} \text {, long } 114^{\circ} 07^{\prime} 46^{\prime \prime} \text {, near } \\
\text { east edge, sec. } 20, \mathrm{~T} .10 \mathrm{~N}, \text {, R. } 20 \\
\text { W., Ravalli County, } 4.0 \mathrm{mi} \text { upstream } \\
\text { from mouth, and } 2.5 \mathrm{mi} \text { southwest } \\
\text { of Florence, Mont. }\end{array}$ & $\begin{array}{l}04-03-58 \\
04-23-58 \\
05-15-58 \\
05-26-58 \\
06-18-58 \\
07-09-58 \\
08-05-58 \\
09-13-58 \\
10-15-58 \\
11-23-58 \\
01-04-59 \\
02-02-59 \\
03-05-59 \\
04-05-59 \\
05-03-59 \\
07-10-59 \\
08-01-59 \\
09-11-59 \\
10-07-59\end{array}$ & $\begin{array}{c}5.80 \\
18.9 \\
78.1 \\
253 \\
94.5 \\
39.2 \\
9.20 \\
2.20 \\
10.2 \\
29.6 \\
6.10 \\
8.20 \\
4.70 \\
23.8 \\
63.8 \\
81.3 \\
29.1 \\
21.7 \\
28.7\end{array}$ \\
\hline
\end{tabular}


Table 1. Streamflow measurements and site descriptions-Continued

\begin{tabular}{|c|c|c|c|c|c|}
\hline $\begin{array}{l}\text { Site } \\
\text { No. }\end{array}$ & $\begin{array}{l}\text { St ream } \\
\text { rome }\end{array}$ & $\begin{array}{l}\text { Tribu- } \\
\text { tary } \\
\text { to }\end{array}$ & Location & Date & $\begin{array}{l}\text { Dis- } \\
\text { charge } \\
\text { (ft } 3 / \mathrm{s})\end{array}$ \\
\hline \multicolumn{6}{|c|}{ Pend Oreille River Basin--Continued } \\
\hline 69 & $\begin{array}{l}\text { Butler } \\
\text { Creek }\end{array}$ & $\begin{array}{l}\text { Clark } \\
\text { Fork }\end{array}$ & $\begin{array}{l}\text { Lat } 47^{\circ} 07^{\prime} 33^{\prime \prime}, \text { long } 114^{\circ} 26^{\prime} 09^{\prime \prime} \text {, in } \\
\text { SExSW/4SW/4 sec. 19, T. } 16 \text { N., R. } 22 \\
\text { W., Missoula Count, Lolo National } \\
\text { Forest, at U.S. Forest Service } \\
\text { bridge, } 2.6 \mathrm{mi} \text { upstream from Nine- } \\
\text { mile Creek, } 4.5 \mathrm{mi} \text { northwest of } \\
\text { Ninemile Ranger Station, and } 8.7 \mathrm{mi} \\
\text { north of Alberton, Mont. }\end{array}$ & $\begin{array}{l}03-17-82 \\
04-14-82 \\
05-20-82 \\
06-17-82 \\
07-15-82 \\
08-19-82 \\
09-18-82 \\
10-21-82 \\
11-18-82 \\
12-16-82 \\
01-19-83 \\
02-16-83\end{array}$ & $\begin{array}{c}3.26 \\
20.7 \\
32.7 \\
127 \\
24.8 \\
6.95 \\
4.10 \\
2.63 \\
2.74 \\
2.76 \\
2.30 \\
2.67\end{array}$ \\
\hline 71 & $\begin{array}{l}\text { Twelve- } \\
\text { mile } \\
\text { Creek }\end{array}$ & $\begin{array}{l}\text { St. Regis } \\
\text { River }\end{array}$ & 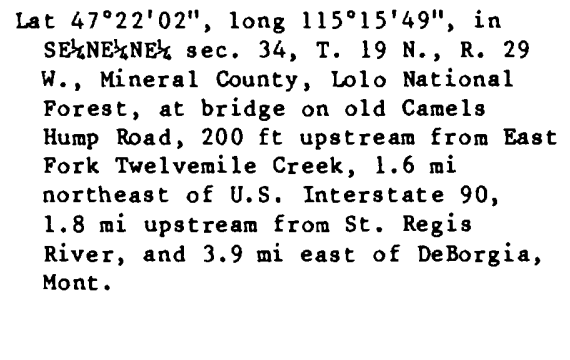 & $\begin{array}{l}03-16-82 \\
04-15-82 \\
05-19-82 \\
06-16-82 \\
07-14-82 \\
08-18-82 \\
09-17-82 \\
10-20-82 \\
11-17-82 \\
12-16-82 \\
01-19-83 \\
02-16-83\end{array}$ & $\begin{array}{c}57.1 \\
136 \\
316 \\
149 \\
43.0 \\
18.8 \\
10.6 \\
13.2 \\
14.7 \\
9.18 \\
14.5 \\
12.9\end{array}$ \\
\hline 72 & $\begin{array}{l}\text { Ward } \\
\text { Creek }\end{array}$ & $\begin{array}{l}\text { St. Regis } \\
\text { River }\end{array}$ & 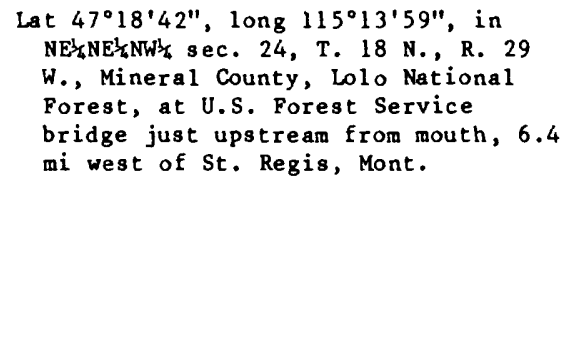 & $\begin{array}{l}04-15-82 \\
05-19-82 \\
06-16-82 \\
07-14-82 \\
08-18-82 \\
09-17-82 \\
10-20-82 \\
11-17-82 \\
12-16-82 \\
01-19-83 \\
02-16-83 \\
03-16-83\end{array}$ & $\begin{array}{l}93.6 \\
214 \\
232 \\
48.1 \\
15.0 \\
10.5 \\
10.5 \\
9.74 \\
13.5 \\
13.2 \\
12.9 \\
51.6\end{array}$ \\
\hline 73 & $\begin{array}{l}\text { Two- } \\
\text { mile } \\
\text { Creek }\end{array}$ & $\begin{array}{l}\text { St. Regis } \\
\text { River }\end{array}$ & 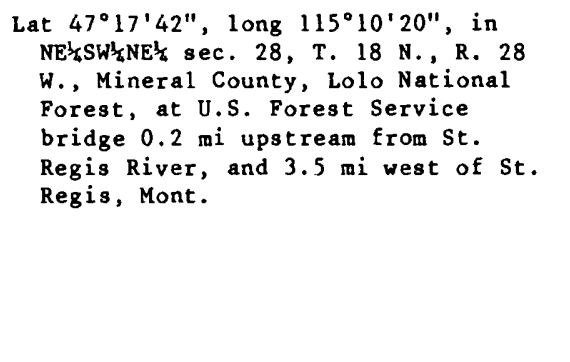 & $\begin{array}{l}03-16-82 \\
04-15-82 \\
05-19-82 \\
06-16-82 \\
07-14-82 \\
08-18-82 \\
09-17-82 \\
10-20-82 \\
11-17-82 \\
12-16-82 \\
01-19-83 \\
02-16-83\end{array}$ & $\begin{array}{c}35.3 \\
59.8 \\
133 \\
102 \\
23.9 \\
9.85 \\
7.23 \\
6.29 \\
6.42 \\
6.70 \\
8.68 \\
7.32\end{array}$ \\
\hline 74 & $\begin{array}{l}\text { St. } \\
\text { Regis } \\
\text { River } \\
(12354000)\end{array}$ & $\begin{array}{l}\text { Clark } \\
\text { Fork }\end{array}$ & $\begin{array}{l}\text { Lat } 47^{\circ} 17^{\prime} 49^{\prime \prime}, \text { long } 115^{\circ} 07^{\prime} 18^{\prime \prime} \text {, near } \\
\text { center of NW/4E } \frac{1}{4} \text { sec. } 26, T \text {. } 18 \mathrm{~N} \text {, } \\
\text { R. } 28 \text { W., Mineral County, } 70 \mathrm{ft} \\
\text { downstream from road bridge, } 500 \mathrm{ft} \\
\text { upstream from Little Joe Creek, } 1.7 \\
\text { mi upstream from mouth, } 1.2 \mathrm{mi} \\
\text { west of St. Regis, and at site of } \\
\text { former gaging station. }\end{array}$ & $\begin{array}{l}03-16-82 \\
04-15-82 \\
05-19-82 \\
06-16-82 \\
07-14-82 \\
08-18-82 \\
09-17-82 \\
10-20-82 \\
11-17-82 \\
12-16-82 \\
01-19-83 \\
02-16-83 \\
03-16-83\end{array}$ & $\begin{array}{r}960 \\
1,580 \\
2,550 \\
2,370 \\
660 \\
185 \\
130 \\
123 \\
127 \\
149 \\
258 \\
188 \\
1,050\end{array}$ \\
\hline
\end{tabular}


Table 1. Streamflow measurements and site descriptions-Continued

\begin{tabular}{|c|c|c|c|c|c|}
\hline $\begin{array}{l}\text { Site } \\
\text { No. }\end{array}$ & $\begin{array}{c}\text { Stream } \\
\text { name }\end{array}$ & $\begin{array}{l}\text { Tribu- } \\
\text { tary } \\
\text { to }\end{array}$ & Location & Date & $\begin{array}{l}\text { Dis- } \\
\text { charge } \\
(\mathrm{ft} 3 / \mathrm{s})\end{array}$ \\
\hline \multicolumn{6}{|c|}{ Pend Oreille River Basin--Continued } \\
\hline 75 & $\begin{array}{l}\text { Siegel } \\
\text { Creek }\end{array}$ & $\begin{array}{l}\text { Clark } \\
\text { Fork }\end{array}$ & $\begin{array}{l}\text { Lat } 47^{\circ} 18^{\prime} 54^{\prime \prime} \text {, long } 114^{\circ} 48^{\prime} 26^{\prime \prime} \text {, in } \\
\text { NW' } \text { SWL }_{4} \mathrm{SE}^{\frac{1}{4} \mathrm{sec} .} 17, \mathrm{~T} \text {. } 18 \mathrm{~N} ., \mathrm{R} \text {. } 25 \\
\text { W. S Sanders County, at culvert on } \\
\text { FAS } 461,1.5 \mathrm{mi} \text { southwest of Quinns } \\
\text { Hot Springs, and } 5.0 \mathrm{mi} \text { south of } \\
\text { Paradise, Mont. }\end{array}$ & $\begin{array}{l}04-14-82 \\
05-19-82 \\
06-16-82 \\
07-14-82 \\
08-18-82 \\
09-17-82 \\
10-20-82 \\
11-17-82 \\
12-15-82 \\
01-19-83 \\
02-16-83 \\
03-16-83\end{array}$ & $\begin{array}{c}28.0 \\
55.0 \\
44.1 \\
11.5 \\
5.97 \\
4.47 \\
4.58 \\
3.75 \\
3.62 \\
4.70 \\
3.62 \\
12.8\end{array}$ \\
\hline 77 & $\begin{array}{l}\text { Bear } \\
\text { Creek } \\
(12356500)\end{array}$ & $\begin{array}{l}\text { Middle } \\
\text { Fork } \\
\text { Flat- } \\
\text { head } \\
\text { River }\end{array}$ & 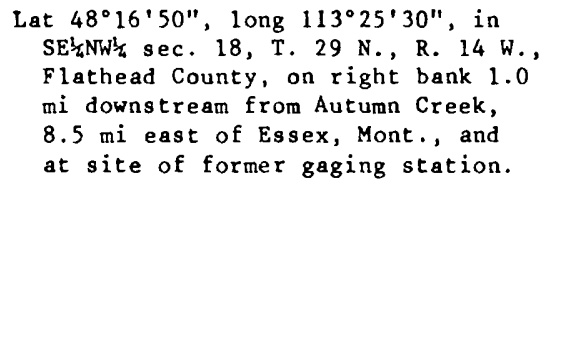 & $\begin{array}{l}03-17-82 \\
04-13-82 \\
05-17-82 \\
06-16-82 \\
07-19-82 \\
08-19-82 \\
09-16-82 \\
10-18-82 \\
11-18-82 \\
12-16-82 \\
01-13-83 \\
02-14-83\end{array}$ & $\begin{array}{c}7.60 \\
16.6 \\
212 \\
320 \\
36.8 \\
16.6 \\
13.6 \\
11.0 \\
11.0 \\
10.1 \\
8.04 \\
8.17\end{array}$ \\
\hline 79 & $\begin{array}{l}\text { Fish } \\
\text { Creek }\end{array}$ & $\begin{array}{l}\text { McDonald } \\
\text { Creek }\end{array}$ & $\begin{array}{l}\text { Lat } 48^{\circ} 33^{\prime} 51^{\prime \prime}, \text { long } 113^{\circ} 59^{\prime} 29^{\prime \prime} \text {, in } \\
\text { T. } 32^{\mathrm{N} .} \text {, R. } 19 \mathrm{~W}, \text { Flathead County, } \\
50 \text { ft upstream from Fish Creek } \\
\text { Campground loop road, 0.1 mi east } \\
\text { of Fish Creek Ranger station, } 0.5 \\
\text { mi east of Glacier Route Eight } \\
\text { Highway, and } 1.6 \mathrm{mi} \text { north of Apgar, } \\
\text { Mont. }\end{array}$ & $\begin{array}{l}09-18-74 \\
05-12-75 \\
06-05-75\end{array}$ & $\begin{array}{c}5.05 \\
109 \\
95.4\end{array}$ \\
\hline 85 & $\begin{array}{l}\text { Piper } \\
\text { Creek }\end{array}$ & $\begin{array}{l}\text { Swan } \\
\text { River }\end{array}$ & 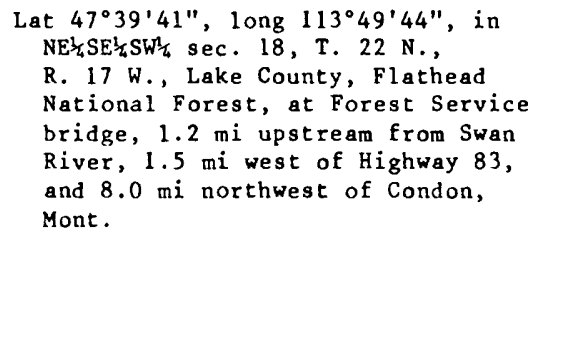 & $\begin{array}{l}03-15-82 \\
04-19-82 \\
05-17-82 \\
06-14-82 \\
07-13-82 \\
08-17-82 \\
09-16-82 \\
10-18-82 \\
11-15-82 \\
12-13-82 \\
01-17-83 \\
02-14-83\end{array}$ & $\begin{array}{c}7.92 \\
14.4 \\
83.6 \\
128 \\
50.3 \\
15.7 \\
8.05 \\
21.3 \\
9.15 \\
10.7 \\
5.57 \\
3.48\end{array}$ \\
\hline 86 & $\begin{array}{l}\text { Goat } \\
\text { Creek } \\
\text { above } \\
\text { Scout } \\
\text { Creek }\end{array}$ & $\begin{array}{l}\text { Swan } \\
\text { River }\end{array}$ & 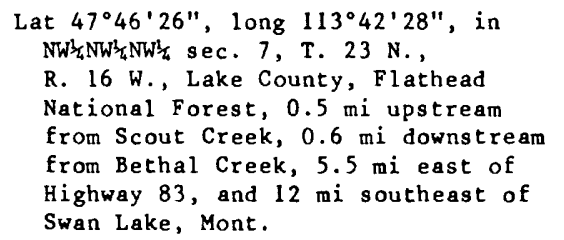 & $\begin{array}{l}05-17-82 \\
06-14-82 \\
07-13-82 \\
08-17-82 \\
09-16-82 \\
10-19-82 \\
11-16-82 \\
12-14-82\end{array}$ & $\begin{array}{r}69.7 \\
137 \\
29.3 \\
3.55 \\
.16 \\
.96 \\
.07 \\
.35\end{array}$ \\
\hline
\end{tabular}


Table 1. Streamflow measurements and site descriptions-Continued

\begin{tabular}{|c|c|c|c|c|c|}
\hline $\begin{array}{c}\text { Site } \\
\text { No. }\end{array}$ & $\begin{array}{l}\text { Stream } \\
\text { name }\end{array}$ & $\begin{array}{l}\text { Tribu- } \\
\text { tary } \\
\text { to }\end{array}$ & Location & Date & $\begin{array}{c}\text { Dis- } \\
\text { charge } \\
\left(\mathrm{ft}^{3} / \mathrm{s}\right)\end{array}$ \\
\hline
\end{tabular}

Pend Oreille River Basin--Continued

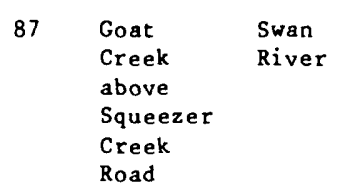

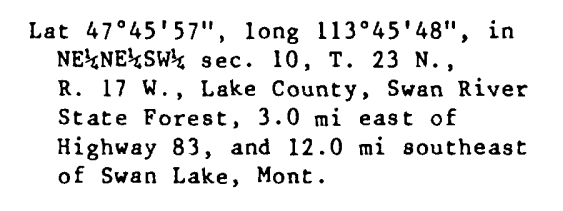

$\begin{array}{cc}03-15-82 & 9.65 \\ 04-19-82 & 9.18 \\ 05-17-82 & 93.2 \\ 06-14-82 & 159 \\ 07-13-82 & 53.6 \\ 08-17-82 & 17.1 \\ 09-16-82 & 10.1 \\ 10-19-82 & 10.8 \\ 11-16-82 & 11.3 \\ 12-14-82 & 8.32 \\ 01-17-83 & 7.13 \\ 02-14-83 & 6.56\end{array}$

$\begin{array}{lll}88 & \text { Goat } & \text { Swan } \\ \text { Creek } & \text { River } \\ \text { at } & \\ \text { Squeezer } & \\ \text { Creek } & \\ \text { Road } & \end{array}$
Lat $47^{\circ} 45^{\prime} 19^{\prime \prime}$, I ong $113^{\circ} 47^{\prime} 23^{\prime \prime}$, in NW: NW: R. 17 W., Lake County, Swan River State Forest, at U.S. Forest Ser- vice bridge on Old Squeezer Creek road, $1.5 \mathrm{mi}$ east of Highway 83 , and $12.0 \mathrm{mi}$ southeast of Swan Lake, Mont.

03-15-82

$\begin{array}{ll}04-19-82 & 9.37\end{array}$

$05-17-82 \quad 89.0$

$06-14-82 \quad 153$

$07-13-82 \quad 49.5$

$08-17-82 \quad 17.8$

$09-16-82 \quad 11.7$

$10-19-82 \quad 10.6$

$11-16-82 \quad 9.59$

12-14-82 9.64

$01-17-83 \quad 6.32$

02-16-83 5.76

\begin{tabular}{|c|c|c|}
\hline 89 & $\begin{array}{l}\text { South } \\
\text { Wood- } \\
\text { ward } \\
\text { Creek } \\
\text { above } \\
\text { Fatty } \\
\text { Creek } \\
\text { Road }\end{array}$ & $\begin{array}{l}\text { Swan } \\
\text { Lake }\end{array}$ \\
\hline 90 & $\begin{array}{l}\text { South } \\
\text { Wood- } \\
\text { ward } \\
\text { Creek } \\
\text { near } \\
\text { mouth }\end{array}$ & $\begin{array}{l}\text { Swan } \\
\text { River }\end{array}$ \\
\hline
\end{tabular}

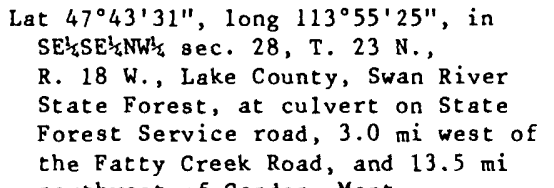

05-17-82 7.93

06-14-82 14.5

07-13-82 12.1

08-17-82 11.0

$\begin{array}{ll}10-18-82 & 7.57 \\ 11-15-82 & 5.84\end{array}$

northwest of Condon, Mont. 11-15-82 5.84

Lat $47^{\circ} 43^{\prime} 19^{\prime \prime}$, long $113^{\circ} 51^{\prime} 20^{\prime \prime}$, in 03-15-82 21.9 NE $\frac{1}{4} N_{W} \frac{1}{4} W_{1} / 4$ sec. 25, T. 23 N., R. 18 04-19-82 21.1 W., Lake County, Flathead National 05-17-82 46.4 Forest, at bridge on U.S. Forest $06-14-82 \quad 40.3$ Service road, $1.5 \mathrm{mi}$ west of High- 07-13-82 42.4 way 83 , and $11.0 \mathrm{mi}$ northwest of $08-17-82 \quad 41.7$ Condon, Mont.

09-16-82 42.0

10-18-82 35.1

11-15-82 32.0

$12-14-82 \quad 23.0$

01-17-83 21.0

$02-14-83 \quad 20.0$

91 Soup $\quad \begin{array}{ll}\text { Swan } \\ \text { Creek } & \text { River }\end{array}$

above

Soup

Creek

Camp-

ground

$\begin{array}{ll}\text { Soup } & \text { Swan } \\ \text { Creek } & \text { River } \\ \text { at } & \\ \text { Soup } & \\ \text { Creek } & \\ \text { Camp- } & \\ \text { ground } & \end{array}$


Table 1. Streamflow measurements and site descriptions-Continued

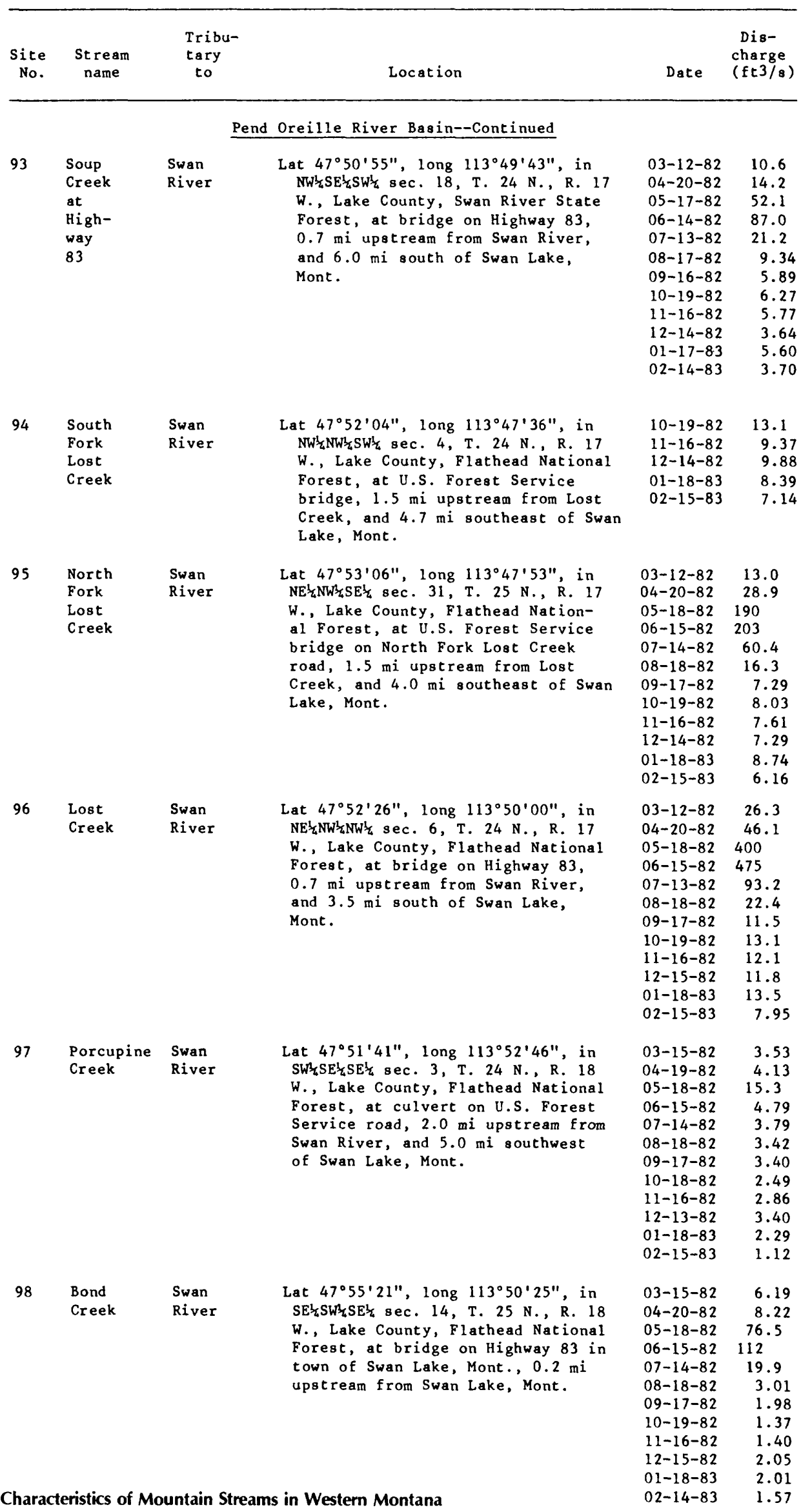


Table 1. Streamflow measurements and site descriptions-Continued

\begin{tabular}{|c|c|c|c|c|c|}
\hline $\begin{array}{l}\text { Site } \\
\text { No. }\end{array}$ & $\begin{array}{c}\text { Stream } \\
\text { name }\end{array}$ & $\begin{array}{l}\text { Tribu- } \\
\text { tary } \\
\text { to }\end{array}$ & Location & Date & $\begin{array}{l}\text { Dis- } \\
\text { charge } \\
\left(\mathrm{ft} \mathrm{t}^{3} / \mathrm{s}\right)\end{array}$ \\
\hline \multicolumn{6}{|c|}{ Pend Oreille River Basin--Continued } \\
\hline 99 & $\begin{array}{l}\text { Hall } \\
\text { Creek }\end{array}$ & $\begin{array}{l}\text { Swan } \\
\text { River }\end{array}$ & $\begin{array}{l}\text { Lat } 47^{\circ} 56^{\prime} 17^{\prime \prime}, \text { long } 113^{\circ} 50^{\prime} 25^{\prime \prime} \text {, in } \\
\text { NW' sec. } 11, \mathrm{~T} \text {, } 25 \mathrm{~N} . \text {, R. } 18 \mathrm{~W} ., \\
\text { Lake County, at unimproved road } \\
\text { crossing about } 0.7 \mathrm{mi} \text { east of junc- } \\
\text { tion with Highway } 83 \text {, at Swan Lake, } \\
\text { Mont. }\end{array}$ & $\begin{array}{l}09-12-74 \\
05-15-75 \\
06-30-75 \\
09-10-75\end{array}$ & $\begin{array}{c}4.79 \\
65.8 \\
20.7 \\
4.36\end{array}$ \\
\hline 100 & $\begin{array}{l}\text { Johnson } \\
\text { Creek }\end{array}$ & Swan River & $\begin{array}{l}\text { Lat } 48^{\circ} 01^{\prime} 19^{\prime \prime}, \text { long } 113^{\circ} 58^{\prime} 05^{\prime \prime} \text {, in } \\
\text { NW' sec. } 14, \text { T. } 26 \mathrm{~N}, \mathrm{R}, 19 \mathrm{~W} ., \\
\text { Lake County, at bridge on unpaved } \\
\text { road, } 1.3 \mathrm{mi} \text { northwest of junction } \\
\text { with Highway } 83,2.1 \mathrm{mi} \text { south of } \\
\text { Flathead-Lake County line, and } 9.0 \\
\text { mi northwest of Swan Lake, Mont. }\end{array}$ & $\begin{array}{l}09-12-74 \\
05-16-75 \\
06-30-75 \\
09-10-75\end{array}$ & $\begin{array}{c}3.46 \\
27.3 \\
14.1 \\
3.97\end{array}$ \\
\hline 102 & $\begin{array}{l}\text { Stoner } \\
\text { Creek }\end{array}$ & $\begin{array}{l}\text { Flat- } \\
\text { head } \\
\text { River }\end{array}$ & $\begin{array}{l}\text { Lat } 48^{\circ} 01^{\prime} 00^{\prime \prime}, \text { long } 114^{\circ} 13^{\prime} 25^{\prime \prime} \text {, in } \\
\text { NW' sec. 18, T. } 26 \mathrm{~N} ., \mathrm{R} .20 \mathrm{~W} ., \\
\text { Flathead County, at bridge on U.S. } \\
\text { Highway } 93,0.3 \text { mi north of junc- } \\
\text { tion with Stoner Creek road, } 0.2 \\
\text { mi south of Lakeside, Mont. }\end{array}$ & $\begin{array}{l}09-19-74 \\
05-09-75 \\
06-03-75 \\
09-08-75\end{array}$ & $\begin{array}{l}3.56 \\
17.4 \\
46.7 \\
2.32\end{array}$ \\
\hline 105 & $\begin{array}{l}\text { Graves } \\
\text { Creek }\end{array}$ & $\begin{array}{l}\text { Clark } \\
\text { Fork }\end{array}$ & $\begin{array}{l}\text { Lat } 47^{\circ} 41^{\prime} 09^{\prime \prime} \text {, long } 115^{\circ} 24^{\prime} 13^{\prime \prime} \text {, in } \\
\text { NW' } \mathrm{NWW}^{\prime} \mathrm{NE}^{\prime} \mathrm{sec} \text {. } 11, \mathrm{~T} \text {. } 22 \mathrm{~N} \text {., R. } 30 \\
\text { W. , Sanders County, at culvert on } \\
\text { county road, } 0.3 \mathrm{mi} \text { upstream from } \\
\text { Clark Fork, and } 7.0 \mathrm{mi} \text { northwest of } \\
\text { Thompson Falls, Mont. }\end{array}$ & $\begin{array}{l}03-16-82 \\
04-15-82 \\
05-18-82 \\
06-15-82 \\
07-12-82 \\
08-17-82 \\
09-13-82 \\
10-20-82 \\
11-17-82 \\
12-15-82 \\
01-19-83 \\
02-15-83\end{array}$ & $\begin{array}{c}5.31 \\
15.3 \\
265 \\
280 \\
85.5 \\
25.6 \\
13.8 \\
7.74 \\
5.10 \\
3.18 \\
4.36 \\
1.79\end{array}$ \\
\hline 106 & $\begin{array}{l}\text { Deep } \\
\text { Creek }\end{array}$ & $\begin{array}{l}\text { Clark } \\
\text { Fork }\end{array}$ & 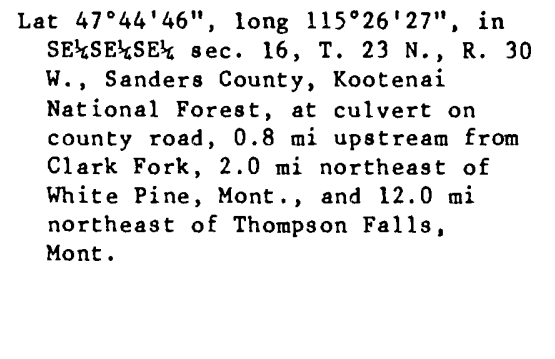 & $\begin{array}{l}03-16-82 \\
04-15-82 \\
05-18-82 \\
06-15-82 \\
07-12-82 \\
08-17-82 \\
09-13-82 \\
10-20-82 \\
11-17-82 \\
12-15-82 \\
01-19-83 \\
02-15-83\end{array}$ & $\begin{array}{c}15.5 \\
39.4 \\
93.5 \\
83.0 \\
24.2 \\
8.30 \\
4.79 \\
3.00 \\
2.91 \\
3.73 \\
6.94 \\
4.07\end{array}$ \\
\hline
\end{tabular}

' Discharge at Red Top Creek site estimated from U.S. Forest Service records. 
Table 2. Annual mean discharge computation for Camp Creek (site 18)

[ $\mathrm{ft}^{3} / \mathrm{s}$, cubic feet per second]

\begin{tabular}{|c|c|c|c|c|c|}
\hline \multirow[b]{2}{*}{ Date } & \multicolumn{3}{|c|}{ Plower Creek (gaged) } & \multicolumn{2}{|c|}{ Camp Creek (ungaged) } \\
\hline & $\begin{array}{c}\text { Recorded } \\
\text { dally mean } \\
\text { dlscharge } \\
\left(\mathrm{ft}^{3} / \mathrm{s}\right)\end{array}$ & $\begin{array}{l}\text { Monthly } \\
\text { mean } \\
\text { discharge } \\
\left(f t^{3} / 8\right)\end{array}$ & $\begin{array}{c}\text { Ratlo of } \\
\text { monthly mean } \\
\text { to daliy } \\
\text { mean }\end{array}$ & $\begin{array}{l}\text { Measured } \\
\text { discharge } \\
\left(\mathrm{ft}^{3} / \mathrm{s}\right)\end{array}$ & $\begin{array}{l}\text { Eocfmated } \\
\text { monthly mean } \\
\text { d1scharge } \\
\left(\mathrm{ft}^{3} / \mathrm{s}\right)\end{array}$ \\
\hline $03-15-82$ & 17 & 14.0 & 0.82 & 15.1 & 12.4 \\
\hline $04-14-82$ & 28 & 20.6 & 0.74 & 20.0 & 14.7 \\
\hline $05-19-82$ & 115 & 83.8 & 0.73 & 82.0 & 59.9 \\
\hline $06-14-82$ & 172 & 127 & 0.74 & 143 & 106 \\
\hline $07-12-82$ & 53 & 50.9 & 0.96 & 47.2 & 45.3 \\
\hline $08-17-82$ & 14 & 14.2 & 1.01 & 6.41 & 6.5 \\
\hline $09-13-82$ & 9.7 & 9.2 & 0.95 & 4.16 & 3.9 \\
\hline $10-13-82$ & 9.4 & 11.2 & 1.19 & 4.78 & 5.7 \\
\hline $11-17-82$ & 8.9 & 9.1 & 1.02 & 4.53 & 4.6 \\
\hline $12-15-82$ & 8.4 & 9.0 & 1.07 & 4.63 & 5.0 \\
\hline $01-19-83$ & 9.2 & 9.4 & 1.02 & 6.20 & 6.3 \\
\hline \multirow[t]{2}{*}{$02-17-83$} & 8.0 & 9.0 & 1.13 & 5.27 & 6.0 \\
\hline & & & \multicolumn{2}{|c|}{ Estloated annual mean discharge } & rge 23.0 \\
\hline
\end{tabular}

'Data used to prepare figure 2.

Table 3. Flow-duration curve computation for Soup Creek above Soup Creek Campground (site 91) [ft ${ }^{3} / \mathrm{s}$, cubic feet per second]

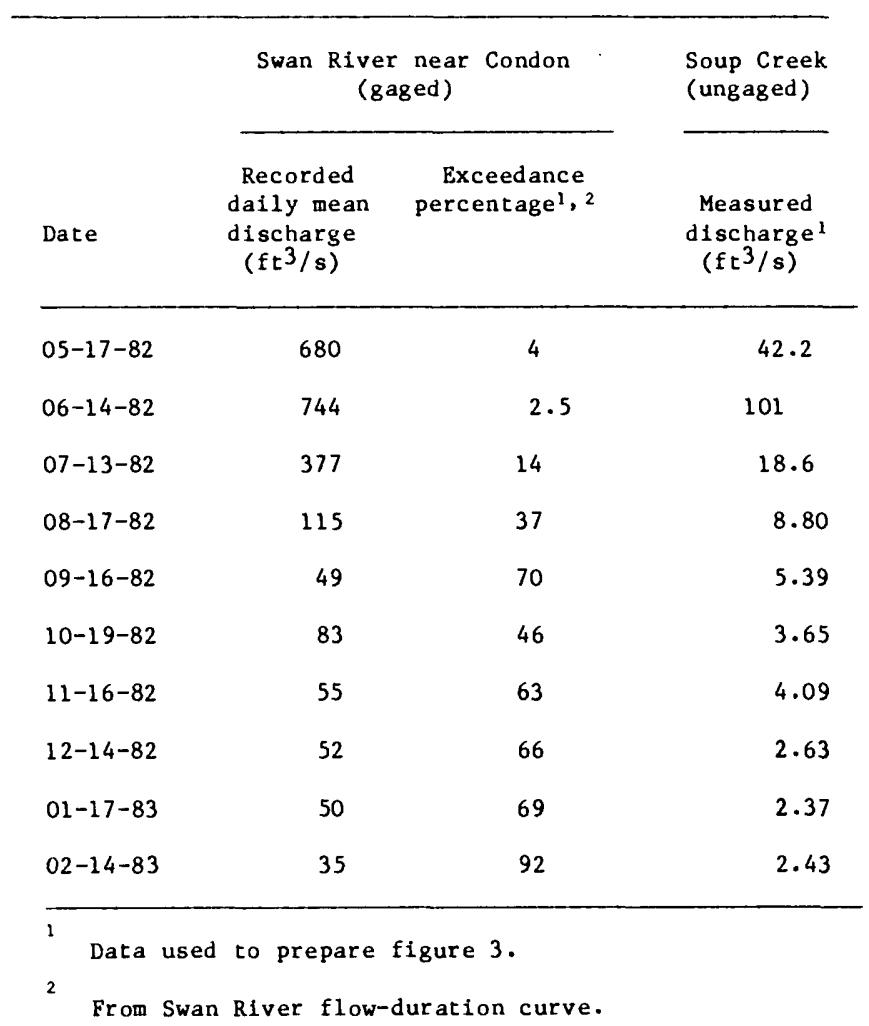


Table 4. Mean annual discharge adjustments for selected gaging stations $\left[\mathrm{ft}^{3} / \mathrm{s}\right.$, cubic feet per second]

\begin{tabular}{|c|c|c|c|c|}
\hline $\begin{array}{l}\text { Site } \\
\text { No. }\end{array}$ & $\begin{array}{l}\text { Stream name and } \\
\text { gaging station number }\end{array}$ & $\begin{array}{l}\text { Actual } \\
\text { period } \\
\text { of } \\
\text { flow } \\
\text { record }\end{array}$ & $\begin{array}{l}\text { Mean annual } \\
\text { discharge } \\
\text { for period } \\
\text { of record } \\
\left(\mathrm{ft}^{3} / \mathrm{s}\right)\end{array}$ & $\begin{array}{c}\text { Mean } \\
\text { annual } \\
\text { discharge } \\
\text { for } 1938-82 \\
\left(\mathrm{ft}^{3} / \mathrm{s}\right)\end{array}$ \\
\hline 4 & Fortine Creek (12300500) & $1948-53$ & 84.7 & 82.0 \\
\hline 6 & Tobacco River (12301300) & $1959-82$ & 273 & 268 \\
\hline 9 & Big Creek near Rexford (12301810) & $1973-81$ & 125 & 149 \\
\hline 14 & Flower Creek (12303100) & $1961-82$ & 27.1 & 27.0 \\
\hline 32 & Yaak River (12304500) & $1957-82$ & 900 & 888 \\
\hline 36 & Middle Fork Rock Creek (12332000) & $1938-82$ & 124 & 124 \\
\hline 39 & Monture Creek (12338690) & $1974-82$ & 197 & 184 \\
\hline 43 & Blackfoot River (12340000) & $1940-82$ & 1,658 & 1,629 \\
\hline 46 & Bitterroot River near Darby (12344000) & $1938-82$ & 934 & 934 \\
\hline 55 & Skalkaho Creek (12346500) & $1949-79$ & 93.5 & 91.0 \\
\hline 57 & Blodgett Creek (12347500) & $1948-69$ & 71.0 & 68.0 \\
\hline 59 & Bear Creek near Victor (12350000) & $1939-59$ & 66.0 & 70.0 \\
\hline 64 & Burnt Fork Bitterroot River (12351000) & $1939-62$ & 48.0 & 50.0 \\
\hline 67 & Eightmile Creek (12351400) & $1958-63$ & 7.20 & 8.00 \\
\hline 70 & Ninemile Creek (12353280) & $1974-82$ & 136 & 124 \\
\hline 74 & St. Regis River (12354000) & $1959-75$ & 580 & 541 \\
\hline 77 & Bear Creek near Essex (12356500) & $1947-52$ & 46.0 & 43.0 \\
\hline 84 & Swan River near Condon (12369200) & $1973-82$ & 168 & 160 \\
\hline 103 & Thompson River (12389500) & $1957-82$ & 479 & 480 \\
\hline 104 & Prospect Creek (12390700) & $1957-82$ & 259 & 258 \\
\hline
\end{tabular}


Table 5. Basin characteristics and mean annual discharge for streamflow-measurement sites (1938-82 base period)

$\left[\mathrm{mi}^{2}\right.$, square miles; $\mathrm{ft}^{3} / \mathrm{s}$, cubic feet per second]

\begin{tabular}{|c|c|c|c|c|c|}
\hline $\begin{array}{l}\text { Site } \\
\text { No. }\end{array}$ & $\begin{array}{l}\text { Stream name and gaging } \\
\text { station number }\end{array}$ & $\begin{array}{l}\text { Drainage } \\
\text { area } \\
\quad\left(m 1^{2}\right)\end{array}$ & $\begin{array}{l}\text { Mean } \\
\text { annual } \\
\text { precip- } \\
\text { itation } \\
\text { (inches) }\end{array}$ & $\begin{array}{c}\text { Mean } \\
\text { annual } \\
\text { discharge } \\
\left(\mathrm{ft}^{3} / \mathrm{s}\right)\end{array}$ & $\begin{array}{l}\text { Mean } \\
\text { annual } \\
\text { runoff } \\
\text { (inches) }\end{array}$ \\
\hline 1 & Young Creek below South Fork & 19.0 & 31 & 15.1 & 10.7 \\
\hline 2 & Young Creek at mouth & 36.0 & 29 & 14.5 & 5.3 \\
\hline 3 & Cayuse Creek (12300400) & 5.29 & 28 & 6.6 & 16.9 \\
\hline 4 & Fortine Creek (12300500) & 112 & 28 & 82.0 & 9.9 \\
\hline 5 & Deep Creek & 18.9 & 50 & 12.8 & 9.2 \\
\hline 7 & Sullivan Creek & 14.1 & 33 & 10.1 & 9.7 \\
\hline 8 & Boulder Creek & 18.1 & 34 & 19.4 & 14.5 \\
\hline 9 & $\begin{array}{l}\text { Big Creek near } \\
\text { Rexford (12301810). }\end{array}$ & 139 & 37 & 149 & 14.5 \\
\hline 10 & Bristow Creek & 25.8 & 34 & 8.0 & 4.2 \\
\hline 15 & Parmenter Creek & 17.7 & 57 & 22.9 & 17.6 \\
\hline 16 & Cedar Creek & 12.9 & 61 & 23.8 & 25.0 \\
\hline 17 & Quartz Creek & 35.4 & 47 & 69.0 & 26.4 \\
\hline 18 & Camp Creek (12303440) & 11.3 & 63 & 19.3 & 23.2 \\
\hline 19 & Ruby Creek & 15.8 & 64 & 26.8 & 23.0 \\
\hline 20 & Pete Creek below Hensley Creek & 29.8 & 35 & 34.7 & 15.8 \\
\hline 21 & Pete Creek at mouth & 33.8 & 34 & 39.4 & 15.8 \\
\hline 22 & Whitetail Creek (12304250) & 2.48 & 35 & 1.7 & 9.3 \\
\hline 23 & Spread Creek & 37.3 & 50 & 80.5 & 29.3 \\
\hline 24 & $\begin{array}{l}\text { Hellroaring Creek at } \\
\text { Forest Service bridge. }\end{array}$ & 9.65 & 70 & 27.0 & 38.0 \\
\hline 25 & Hellroaring Creek at mouth & 16.9 & 66 & 27.6 & 22.2 \\
\hline 26 & North Fork Meadow Creek & 6.33 & 72 & 13.6 & 29.2 \\
\hline 27 & $\begin{array}{l}\text { North Fork Meadow Creek } \\
\text { at mouth. }\end{array}$ & 7.04 & 69 & 13.3 & 25.6 \\
\hline 28 & Meadow Creek & 20.4 & 68 & 42.6 & 28.3 \\
\hline 29 & Red Top Creek & 9.96 & 69 & 19.7 & 26.8 \\
\hline 30 & Cyclone Creek (12304300) & 5.71 & 67 & 10.7 & 25.4 \\
\hline 31 & Fourth of July Creek (12304400) & 7.84 & 64 & 13.1 & 22.7 \\
\hline 40 & Deer Creek (12339300) & 19.8 & 39 & 21.1 & 14.5 \\
\hline 41 & Seeley Creek & 5.11 & 30 & 3.9 & 10.4 \\
\hline
\end{tabular}


Table 5. Basin characteristics and mean annual discharge for streamflow-measurement sites (1938-82 base period)-Continued

\begin{tabular}{|c|c|c|c|c|c|}
\hline $\begin{array}{l}\text { Site } \\
\text { No. }\end{array}$ & $\begin{array}{c}\text { Stream name and gaging } \\
\text { station number }\end{array}$ & $\begin{array}{l}\text { Drainage } \\
\quad \text { area } \\
\quad\left(\mathrm{m} 1^{2}\right)\end{array}$ & $\begin{array}{l}\text { Mean } \\
\text { annual } \\
\text { prec1p- } \\
\text { 1tation } \\
\text { (inches) }\end{array}$ & $\begin{array}{l}\text { Mean } \\
\text { annual } \\
\text { discharge } \\
(\mathrm{ft} 3 / \mathrm{s})\end{array}$ & $\begin{array}{l}\text { Mean } \\
\text { annual } \\
\text { runoff } \\
\text { (1nches) }\end{array}$ \\
\hline 42 & West Tw1n Creek (12339900) & 7.33 & 25 & 11.3 & 20.9 \\
\hline 44 & Marsha11 Creek (12340200) & 5.63 & 23 & 2.3 & 5.5 \\
\hline 47 & Tin Cup Creek & 33.4 & 65 & 91.0 & 37.0 \\
\hline 48 & Burke Gulch (12344300) & 6.28 & 22 & 2.0 & 4.3 \\
\hline 49 & Lost Horse Creek & 66.3 & 68 & 190 & 38.9 \\
\hline 50 & Camas Creek (12345800) & 6.01 & 62 & 15.2 & 34.3 \\
\hline 51 & Sleeping Ch1ld Creek (12345850) & 64.7 & 31 & 58.6 & 12.3 \\
\hline 52 & $\begin{array}{l}\text { Little Sleeplng } \\
\text { Ch1ld Creek. }\end{array}$ & 11.2 & 21 & 3.3 & 4.0 \\
\hline 53 & Roaring Lion Creek & 23.9 & 67 & 63.5 & 36.1 \\
\hline 54 & Sawtooth Creek & 22.6 & 63 & 60.3 & 36.2 \\
\hline 56 & G1rd Creek & 28.8 & 23 & 17.1 & 8.1 \\
\hline 58 & M111 Creek & 17.6 & 62 & 50.3 & 38.8 \\
\hline 60 & Sweat House Creek & 10.2 & 66 & 25.3 & 33.7 \\
\hline 61 & Gash Creek (12350200) & 3.37 & 60 & 10.7 & 43.1 \\
\hline 62 & Big Creek & 32.9 & 61 & 93.3 & 38.5 \\
\hline 65 & Bass Creek & 13.1 & 58 & 27.3 & 28.3 \\
\hline 66 & Sweeney Creek & 16.4 & 60 & 31.0 & 25.7 \\
\hline 69 & Butler Creek & 10.7 & 38 & 11.9 & 15.1 \\
\hline 71 & Twelvem1le Creek & 40.7 & 50 & 44.4 & 14.8 \\
\hline 72 & Ward Creek & 22.8 & 57 & 40.9 & 24.3 \\
\hline 73 & Twom1le Creek & 17.1 & 52 & 23.0 & 18.3 \\
\hline 74 & St. Reg1s River (12354000) & 303 & 52 & 541 & 24.2 \\
\hline 75 & S1egel Creek & 14.2 & 40 & 10.5 & 10.0 \\
\hline 77 & Bear Creek (12356500) & 20.4 & 47 & 43.0 & 28.6 \\
\hline 79 & Fish Creek & 15.3 & 44 & 24.7 & 21.9 \\
\hline 85 & Piper Creek & 11.8 & 55 & 22.2 & 25.5 \\
\hline 86 & $\begin{array}{l}\text { Goat Creek above } \\
\text { Scout Creek. }\end{array}$ & 8.27 & 72 & 24.2 & 39.7 \\
\hline 87 & $\begin{array}{l}\text { Goat Creek above } \\
\text { Squeezer Creek Road. }\end{array}$ & 14.9 & 67 & 24.6 & 22.4 \\
\hline 88 & $\begin{array}{l}\text { Goat Creek at Squeezer } \\
\text { Creek Road. }\end{array}$ & 19.7 & 60 & 24.2 & 16.7 \\
\hline
\end{tabular}


Table 5. Basin characteristics and mean annual discharge for streamflow-measurement sites (1938-82 base period)-Continued

\begin{tabular}{|c|c|c|c|c|c|}
\hline $\begin{array}{l}\text { Site } \\
\text { No. }\end{array}$ & $\begin{array}{l}\text { Stream name and gaging } \\
\text { station number }\end{array}$ & $\begin{array}{l}\text { Dra1nage } \\
\quad \text { area } \\
\quad(\mathrm{m} 12)\end{array}$ & $\begin{array}{l}\text { Mean } \\
\text { annual } \\
\text { precip- } \\
\text { itation } \\
\text { (1nches) }\end{array}$ & $\begin{array}{l}\text { Mean } \\
\text { annual } \\
\text { discharge } \\
(\mathrm{ft} 3 / \mathrm{s})\end{array}$ & $\begin{array}{l}\text { Mean } \\
\text { annual } \\
\text { runoff } \\
\text { (1nches) }\end{array}$ \\
\hline 89 & $\begin{array}{l}\text { South Woodward Creek above } \\
\text { Fatty Creek Road. }\end{array}$ & 2.88 & 60 & 6.2 & 29.2 \\
\hline 90 & South Woodward Creek near mouth & 10.5 & 51 & 25.2 & 32.6 \\
\hline 91 & Soup Creek above Soup Creek Campground & d 4.50 & 67 & 12.2 & 36.8 \\
\hline 92 & Soup Creek at Soup Creek Campground & 5.87 & 61 & 11.2 & 25.9 \\
\hline 93 & Soup Creek at Highway 83 & 14.5 & 49 & 14.0 & 13.1 \\
\hline 94 & South Fork Lost Creek & 14.8 & 61 & 42.9 & 39.3 \\
\hline 95 & North Fork Lost Creek & 13.0 & 60 & 30.7 & 32.0 \\
\hline 96 & Lost Creek & 31.7 & 58 & 61.5 & 26.3 \\
\hline 97 & Porcuplne Creek & 10.0 & 49 & 3.0 & 4.1 \\
\hline 98 & Bond Creek & 7.58 & 53 & 12.8 & 22.9 \\
\hline 99 & Hall Creek & 4.66 & 54 & 12.7 & 37.0 \\
\hline 100 & Johnson Creek & 12.1 & 50 & 6.4 & 7.2 \\
\hline 102 & Stoner Creek & 22.6 & 25 & 11.9 & 7.1 \\
\hline 105 & Graves Creek & 28.3 & 56 & 42.9 & 20.6 \\
\hline 106 & Deep Creek & 12.6 & 56 & 18.2 & 19.6 \\
\hline
\end{tabular}


Table 6. Discharge for various exceedance percentages for streamflow-measurement sites (1938-82 base period)

Discharge, in cubic feet per second, for indicated exceedance percentage

\begin{tabular}{|c|c|c|c|c|c|c|c|c|c|c|}
\hline \multirow{2}{*}{$\begin{array}{l}\text { Site } \\
\text { No. }\end{array}$} & \multirow{2}{*}{$\begin{array}{c}\text { Stream name and gaging } \\
\text { station number }\end{array}$} & & & & & & & & & \\
\hline & & 10 & 20 & 30 & 40 & 50 & 60 & 70 & 80 & 90 \\
\hline 1 & $\begin{array}{l}\text { Young Creek below South } \\
\text { Fork. }\end{array}$ & 40.0 & 28.0 & 21.0 & 16.0 & 12.0 & 8.9 & 6.6 & 5.1 & 4.0 \\
\hline $\begin{array}{l}2 \\
3 \\
4 \\
5\end{array}$ & $\begin{array}{l}\text { Young Creek at mouth } \\
\text { Cayuse Creek }(12300400) \\
\text { Fortine Creek }(12300500) \\
\text { Deep Creek }\end{array}$ & $\begin{array}{r}40.0 \\
20.0 \\
240.0 \\
97.0\end{array}$ & $\begin{array}{r}29.0 \\
7.3 \\
82.5 \\
52.0\end{array}$ & $\begin{array}{r}21.0 \\
2.9 \\
45.0 \\
30.0\end{array}$ & $\begin{array}{r}16.0 \\
1.6 \\
32.5 \\
19.0\end{array}$ & $\begin{array}{r}11.0 \\
1.0 \\
25.0 \\
12.0\end{array}$ & $\begin{array}{r}8.3 \\
.7 \\
19.0 \\
7.4\end{array}$ & $\begin{array}{r}7.0 \\
.5 \\
13.0 \\
4.8\end{array}$ & $\begin{array}{r}6.0 \\
.4 \\
10.0 \\
3.1\end{array}$ & $\begin{array}{r}5.3 \\
.4 \\
8.6 \\
2.0\end{array}$ \\
\hline $\begin{array}{l}7 \\
8 \\
9\end{array}$ & $\begin{array}{l}\text { Sullivan Creek } \\
\text { Boulder Creek } \\
\text { Big Creek near Rexford } \\
\text { (12301810). }\end{array}$ & $\begin{array}{r}29.0 \\
59.0 \\
458.0\end{array}$ & $\begin{array}{r}21.0 \\
39.0 \\
169.0\end{array}$ & $\begin{array}{l}15.0 \\
26.0 \\
83.0\end{array}$ & $\begin{array}{l}11.0 \\
18.5 \\
51.0\end{array}$ & $\begin{array}{r}7.8 \\
12.5 \\
33.0\end{array}$ & $\begin{array}{r}5.4 \\
8.2 \\
27.0\end{array}$ & $\begin{array}{r}3.9 \\
5.7 \\
23.0\end{array}$ & $\begin{array}{r}2.9 \\
3.9 \\
19.0\end{array}$ & $\begin{array}{r}2.0 \\
2.8 \\
15.0\end{array}$ \\
\hline $\begin{array}{l}10 \\
15\end{array}$ & $\begin{array}{l}\text { Bristow Creek } \\
\text { Parmenter Creek }\end{array}$ & $\begin{array}{l}55.0 \\
95.0\end{array}$ & $\begin{array}{l}27.0 \\
45.0\end{array}$ & $\begin{array}{l}14.0 \\
18.0\end{array}$ & $\begin{array}{l}7.1 \\
6.6\end{array}$ & $\begin{array}{l}4.0 \\
2.7\end{array}$ & $\begin{array}{l}2.5 \\
1.4\end{array}$ & $\begin{array}{r}1.8 \\
.7\end{array}$ & $\begin{array}{r}1.3 \\
.4\end{array}$ & $\begin{array}{r}1.0 \\
3\end{array}$ \\
\hline $\begin{array}{l}16 \\
17 \\
18 \\
19 \\
20\end{array}$ & $\begin{array}{l}\text { Cedar Creek } \\
\text { Quartz Creek } \\
\text { Camp Creek (12303440) } \\
\text { Ruby Creek } \\
\text { Pete Creek below Hensley } \\
\text { Creek. }\end{array}$ & $\begin{array}{r}87.0 \\
200.0 \\
66.0 \\
96.0 \\
114.0\end{array}$ & $\begin{array}{r}41.0 \\
110.0 \\
33.0 \\
62.0 \\
59.0\end{array}$ & $\begin{array}{l}21.0 \\
65.0 \\
16.0 \\
39.0 \\
33.0\end{array}$ & $\begin{array}{r}14.0 \\
45.0 \\
9.8 \\
21.0 \\
19.0\end{array}$ & $\begin{array}{r}9.6 \\
34.0 \\
7.1 \\
11.4 \\
12.0\end{array}$ & $\begin{array}{r}7.3 \\
27.0 \\
5.7 \\
7.2 \\
6.9\end{array}$ & $\begin{array}{r}5.8 \\
22.0 \\
4.9 \\
5.1 \\
4.6\end{array}$ & $\begin{array}{r}4.8 \\
19.0 \\
4.4 \\
3.7 \\
3.1\end{array}$ & $\begin{array}{r}4.0 \\
16.0 \\
4.0 \\
3.0 \\
2.3\end{array}$ \\
\hline $\begin{array}{l}21 \\
22 \\
23 \\
24\end{array}$ & $\begin{array}{l}\text { Pete Creek at mouth } \\
\text { Whitetail Creek (12304250) } \\
\text { Spread Creek } \\
\text { Hellroaring Creek at } \\
\text { Forest Service Bridge. }\end{array}$ & $\begin{array}{r}148.0 \\
7.0 \\
148.0 \\
61.0\end{array}$ & $\begin{array}{r}79.0 \\
2.8 \\
60.0 \\
22.0\end{array}$ & $\begin{array}{r}44.0 \\
1.3 \\
38.0 \\
12.0\end{array}$ & $\begin{array}{r}24.0 \\
.7 \\
27.0 \\
7.8\end{array}$ & $\begin{array}{r}12.0 \\
.3 \\
22.0 \\
5.9\end{array}$ & $\begin{array}{r}6.9 \\
.1 \\
19.0 \\
4.9\end{array}$ & $\begin{array}{r}4.6 \\
.0 \\
17.0 \\
4.4\end{array}$ & $\begin{array}{r}3.1 \\
.0 \\
15.0 \\
4.0\end{array}$ & $\begin{array}{r}2.3 \\
.0 \\
13.0 \\
3.7\end{array}$ \\
\hline 25 & Hellroaring Creek at mouth & 73.0 & 31.0 & 16.0 & 10.0 & 7.1 & 5.1 & 3.9 & 3.0 & 2.4 \\
\hline $\begin{array}{l}26 \\
27\end{array}$ & $\begin{array}{l}\text { North Fork Meadow Creek } \\
\text { North Fork Meadow Creek } \\
\text { at mouth. }\end{array}$ & $\begin{array}{l}36.0 \\
36.0\end{array}$ & $\begin{array}{l}15.0 \\
15.0\end{array}$ & $\begin{array}{l}8.2 \\
8.2\end{array}$ & $\begin{array}{l}5.6 \\
5.6\end{array}$ & $\begin{array}{l}4.5 \\
4.5\end{array}$ & $\begin{array}{l}3.4 \\
3.4\end{array}$ & $\begin{array}{l}2.7 \\
2.7\end{array}$ & $\begin{array}{l}2.2 \\
2.2\end{array}$ & $\begin{array}{l}1.8 \\
1.8\end{array}$ \\
\hline $\begin{array}{l}28 \\
29 \\
30\end{array}$ & $\begin{array}{l}\text { Meadow Creek } \\
\text { Red Top Creek } \\
\text { Cyclone Creek (12304300) }\end{array}$ & $\begin{array}{r}109.0 \\
65.0 \\
32.0\end{array}$ & $\begin{array}{l}55.0 \\
27.0 \\
16.0\end{array}$ & $\begin{array}{r}32.0 \\
13.0 \\
8.9\end{array}$ & $\begin{array}{r}20.0 \\
8.1 \\
5.9\end{array}$ & $\begin{array}{r}13.0 \\
5.9 \\
4.3\end{array}$ & $\begin{array}{l}8.5 \\
4.6 \\
3.3\end{array}$ & $\begin{array}{l}6.1 \\
3.8 \\
2.6\end{array}$ & $\begin{array}{l}4.4 \\
3.2 \\
2.2\end{array}$ & $\begin{array}{l}3.4 \\
2.7 \\
1.8\end{array}$ \\
\hline 31 & $\begin{array}{l}\text { Fourth of July Creek } \\
(12304400)\end{array}$ & 44.0 & 18.0 & 8.9 & 5.7 & 4.0 & 3.1 & 2.6 & 2.2 & 1.9 \\
\hline $\begin{array}{l}40 \\
41 \\
42 \\
44\end{array}$ & $\begin{array}{l}\text { Deer Creek }(12339300) \\
\text { Seeley Creek } \\
\text { West Twin Creek (12339900) } \\
\text { Marshall Creek (12340200) }\end{array}$ & $\begin{array}{r}61.0 \\
7.4 \\
34.0 \\
10.5\end{array}$ & $\begin{array}{r}29.0 \\
5.4 \\
20.0 \\
7.2\end{array}$ & $\begin{array}{r}14.0 \\
4.0 \\
12.5 \\
5.2\end{array}$ & $\begin{array}{l}8.2 \\
3.2 \\
7.8 \\
3.8\end{array}$ & $\begin{array}{l}5.4 \\
2.6 \\
5.0 \\
2.7\end{array}$ & $\begin{array}{l}4.0 \\
2.3 \\
3.5 \\
2.0\end{array}$ & $\begin{array}{l}3.0 \\
2.0 \\
2.5 \\
1.4\end{array}$ & $\begin{array}{l}2.5 \\
1.9 \\
1.9 \\
1.1\end{array}$ & $\begin{array}{r}2.1 \\
1.8 \\
1.4 \\
.8\end{array}$ \\
\hline $\begin{array}{l}47 \\
48 \\
49 \\
50 \\
51\end{array}$ & $\begin{array}{l}\text { Tin Cup Creek } \\
\text { Burke Gulch }(12344300) \\
\text { Lost Horse Creek } \\
\text { Camas Creek }(12345800) \\
\text { Sleeping Child Creek } \\
(12345850) .\end{array}$ & $\begin{array}{r}255.0 \\
3.5 \\
636.0 \\
22.0 \\
129.0\end{array}$ & $\begin{array}{r}140.0 \\
1.9 \\
340.0 \\
8.7 \\
60.0\end{array}$ & $\begin{array}{r}84.0 \\
1.0 \\
164.0 \\
5.1 \\
35.5\end{array}$ & $\begin{array}{r}54.0 \\
.6 \\
91.0 \\
3.5 \\
25.0\end{array}$ & $\begin{array}{r}36.0 \\
.4 \\
59.0 \\
2.5 \\
19.0\end{array}$ & $\begin{array}{r}25.0 \\
.3 \\
42.0 \\
2.0 \\
15.5\end{array}$ & $\begin{array}{r}18.5 \\
.2 \\
31.0 \\
1.5 \\
13.0\end{array}$ & $\begin{array}{r}13.6 \\
.1 \\
25.0 \\
1.3 \\
12.0\end{array}$ & $\begin{array}{r}10.0 \\
.1 \\
21.0 \\
1.1 \\
11.0\end{array}$ \\
\hline 52 & $\begin{array}{l}\text { Little Sleeping Child } \\
\text { Creek. }\end{array}$ & 8.9 & 5.0 & 3.0 & 1.9 & 1.3 & .9 & .7 & .6 & .5 \\
\hline $\begin{array}{l}53 \\
54 \\
56 \\
58\end{array}$ & $\begin{array}{l}\text { Roaring Lion Creek } \\
\text { Sawt ooth Creek } \\
\text { Gird Creek } \\
\text { Mill Creek }\end{array}$ & $\begin{array}{r}195.0 \\
186.0 \\
36.0 \\
161.0\end{array}$ & $\begin{array}{r}107.0 \\
83.0 \\
23.0 \\
71.0\end{array}$ & $\begin{array}{l}60.0 \\
38.5 \\
16.0 \\
33.0\end{array}$ & $\begin{array}{l}34.0 \\
23.0 \\
12.5 \\
19.0\end{array}$ & $\begin{array}{l}21.5 \\
16.0 \\
10.0 \\
12.5\end{array}$ & $\begin{array}{r}14.0 \\
12.0 \\
8.6 \\
8.7\end{array}$ & $\begin{array}{l}9.5 \\
9.3 \\
7.3 \\
6.5\end{array}$ & $\begin{array}{l}6.6 \\
7.7 \\
6.3 \\
5.0\end{array}$ & $\begin{array}{l}4.6 \\
6.4 \\
5.7 \\
4.0\end{array}$ \\
\hline $\begin{array}{l}60 \\
61 \\
62 \\
65 \\
66\end{array}$ & $\begin{array}{l}\text { Sweat House Creek } \\
\text { Gash Creek (12350200) } \\
\text { Big Creek } \\
\text { Bass Creek } \\
\text { Sweeney Creek }\end{array}$ & $\begin{array}{r}74.0 \\
21.0 \\
260.0 \\
72.0 \\
103.0\end{array}$ & $\begin{array}{r}37.0 \\
9.6 \\
125.0 \\
44.0 \\
63.0\end{array}$ & $\begin{array}{r}23.0 \\
5.6 \\
68.0 \\
29.0 \\
40.0\end{array}$ & $\begin{array}{r}13.0 \\
3.8 \\
44.0 \\
22.0 \\
26.0\end{array}$ & $\begin{array}{r}8.8 \\
2.8 \\
31.0 \\
17.0 \\
18.0\end{array}$ & $\begin{array}{r}6.3 \\
2.2 \\
24.0 \\
13.0 \\
13.0\end{array}$ & $\begin{array}{r}4.6 \\
1.8 \\
19.0 \\
11.0 \\
9.6\end{array}$ & $\begin{array}{r}3.5 \\
1.5 \\
16.0 \\
8.2 \\
7.1\end{array}$ & $\begin{array}{r}2.6 \\
1.4 \\
14.0 \\
6.3 \\
5.2\end{array}$ \\
\hline $\begin{array}{l}69 \\
71 \\
72 \\
73 \\
74\end{array}$ & $\begin{array}{l}\text { Butler Creek } \\
\text { Twelvemile Creek } \\
\text { Ward Creek } \\
\text { Twomile Creek } \\
\text { St. Regis River } \\
\text { (12354000). }\end{array}$ & $\begin{array}{r}49.5 \\
105.0 \\
87.0 \\
56.0 \\
1,500.0\end{array}$ & $\begin{array}{r}23.0 \\
47.0 \\
52.5 \\
35.5 \\
823.0\end{array}$ & $\begin{array}{r}11.5 \\
27.0 \\
33.0 \\
20.0 \\
465.0\end{array}$ & $\begin{array}{r}6.4 \\
19.0 \\
21.5 \\
12.0 \\
304.0\end{array}$ & $\begin{array}{r}4.1 \\
14.5 \\
15.5 \\
9.0 \\
211.0\end{array}$ & $\begin{array}{r}2.9 \\
12.0 \\
12.0 \\
7.2 \\
163.0\end{array}$ & $\begin{array}{r}2.1 \\
10.0 \\
9.8 \\
6.1 \\
134.0\end{array}$ & $\begin{array}{r}1.7 \\
8.8 \\
8.4 \\
5.4 \\
112.0\end{array}$ & $\begin{array}{r}1.5 \\
8.0 \\
7.2 \\
4.7 \\
94.0\end{array}$ \\
\hline $\begin{array}{l}75 \\
77 \\
79\end{array}$ & $\begin{array}{l}\text { Siegel Creek } \\
\text { Bear Creek (12356500) } \\
\text { Fish Creek }\end{array}$ & $\begin{array}{r}28.0 \\
130.0 \\
94.0\end{array}$ & $\begin{array}{l}14.0 \\
51.0 \\
56.0\end{array}$ & $\begin{array}{r}8.8 \\
29.0 \\
31.0\end{array}$ & $\begin{array}{r}6.6 \\
20.5 \\
18.0\end{array}$ & $\begin{array}{r}5.2 \\
16.0 \\
12.0\end{array}$ & $\begin{array}{r}4.3 \\
13.0 \\
10.0\end{array}$ & $\begin{array}{r}3.8 \\
10.0 \\
8.5\end{array}$ & $\begin{array}{l}3.4 \\
8.4 \\
7.5\end{array}$ & $\begin{array}{l}3.1 \\
6.9 \\
6.9\end{array}$ \\
\hline
\end{tabular}


Table 6. Discharge for various exceedance percentages for streamflow-measurement sites (1938-82 base perio 1 )-Continued

\begin{tabular}{|c|c|c|c|c|c|c|c|c|c|c|}
\hline \multirow[b]{2}{*}{$\begin{array}{l}\text { Site } \\
\text { No. }\end{array}$} & \multirow[b]{2}{*}{$\begin{array}{l}\text { Stream name and gaging } \\
\text { station number }\end{array}$} & \multicolumn{9}{|c|}{$\begin{array}{l}\text { Discharge, in cubic feet per second, for } \\
\text { indicated exceedance percentage }\end{array}$} \\
\hline & & 10 & 20 & 30 & 40 & 50 & 60 & 70 & 80 & 90 \\
\hline $\begin{array}{l}85 \\
86\end{array}$ & $\begin{array}{l}\text { Piper Creek } \\
\text { Goat Creek above Scout } \\
\text { Creek. }\end{array}$ & $\begin{array}{l}50.0 \\
43.0\end{array}$ & $\begin{array}{l}29.0 \\
15.0\end{array}$ & $\begin{array}{r}20.0 \\
5.5\end{array}$ & $\begin{array}{r}14.0 \\
2.2\end{array}$ & $\begin{array}{r}12.0 \\
.8\end{array}$ & $\begin{array}{r}8.0 \\
.3\end{array}$ & $\begin{array}{r}6.1 \\
.1\end{array}$ & $\begin{array}{r}4.7 \\
.0\end{array}$ & $\begin{array}{r}3.5 \\
.0\end{array}$ \\
\hline 87 & $\begin{array}{l}\text { Goat Creek above Squeezer } \\
\text { Creek Road. }\end{array}$ & 64.0 & 36.0 & 22.0 & 15.0 & 11.0 & 8.5 & 6.7 & 5.4 & 4.7 \\
\hline 88 & $\begin{array}{l}\text { Goat Creek at Squeezer } \\
\text { Creek Road. }\end{array}$ & 58.0 & 31.0 & 20.0 & 13.5 & 10.0 & 7.7 & 6.3 & 5.2 & 4.5 \\
\hline 89 & $\begin{array}{l}\text { South Woodward Creek above } \\
\text { Fatty Creek Road. }\end{array}$ & 11.5 & 10.0 & 9.0 & 8.1 & 7.2 & 6.4 & 5.7 & 5.0 & 4.2 \\
\hline 90 & $\begin{array}{l}\text { South Woodward Creek near } \\
\text { mouth. }\end{array}$ & 38.0 & 36.0 & 34.0 & 31.0 & 29.5 & 27.5 & 25.5 & 24.0 & 21.0 \\
\hline 91 & $\begin{array}{l}\text { Soup Creek above Soup } \\
\text { Creek Campground. }\end{array}$ & 24.0 & 14.5 & 10.0 & 7.3 & 5.4 & 4.1 & 3.3 & 2.6 & 2.0 \\
\hline 92 & $\begin{array}{l}\text { Soup Creek at Soup Creek } \\
\text { Campground. }\end{array}$ & 20.0 & 9.2 & 6.1 & 4.4 & 3.5 & 2.8 & 2.4 & 2.0 & 1.7 \\
\hline $\begin{array}{l}93 \\
94 \\
95 \\
96\end{array}$ & $\begin{array}{l}\text { Soup Creek at Highway } 83 \\
\text { South Fork Lost Creek } \\
\text { North Fork Lost Creek } \\
\text { Lost Creek }\end{array}$ & $\begin{array}{r}33.0 \\
74.0 \\
71.0 \\
141.0\end{array}$ & $\begin{array}{l}19.0 \\
42.0 \\
40.0 \\
70.0\end{array}$ & $\begin{array}{l}13.0 \\
26.5 \\
24.0 \\
41.0\end{array}$ & $\begin{array}{r}9.3 \\
18.0 \\
15.0 \\
26.0\end{array}$ & $\begin{array}{r}7.0 \\
13.0 \\
11.0 \\
18.0\end{array}$ & $\begin{array}{r}5.4 \\
10.0 \\
8.3 \\
13.0\end{array}$ & $\begin{array}{r}4.2 \\
8.1 \\
6.5 \\
10.0\end{array}$ & $\begin{array}{l}3.4 \\
6.7 \\
5.3 \\
8.3\end{array}$ & $\begin{array}{l}2.7 \\
5.7 \\
4.4 \\
6.9\end{array}$ \\
\hline $\begin{array}{r}97 \\
98 \\
99 \\
100 \\
102\end{array}$ & $\begin{array}{l}\text { Porcupine Creek } \\
\text { Bond Creek } \\
\text { Hall Creek } \\
\text { Johnson Creek } \\
\text { Stoner Creek }\end{array}$ & $\begin{array}{r}7.6 \\
24.0 \\
37.0 \\
18.0 \\
43.0\end{array}$ & $\begin{array}{r}5.7 \\
12.0 \\
23.0 \\
11.0 \\
13.0\end{array}$ & $\begin{array}{r}4.5 \\
6.9 \\
15.0 \\
7.1 \\
8.0\end{array}$ & $\begin{array}{l}3.6 \\
4.5 \\
9.5 \\
4.5 \\
6.0\end{array}$ & $\begin{array}{l}2.9 \\
3.1 \\
6.8 \\
3.1 \\
4.7\end{array}$ & $\begin{array}{l}2.5 \\
2.2 \\
5.0 \\
2.3 \\
3.7\end{array}$ & $\begin{array}{l}2.0 \\
1.6 \\
3.8 \\
1.7 \\
2.9\end{array}$ & $\begin{array}{l}1.6 \\
1.2 \\
3.1 \\
1.3 \\
2.3\end{array}$ & $\begin{array}{r}1.2 \\
.9 \\
2.4 \\
1.0 \\
1.6\end{array}$ \\
\hline $\begin{array}{l}105 \\
106\end{array}$ & $\begin{array}{l}\text { Graves Creek } \\
\text { Deep Creek }\end{array}$ & $\begin{array}{r}175.0 \\
43.0\end{array}$ & $\begin{array}{l}90.0 \\
23.0\end{array}$ & $\begin{array}{l}45.0 \\
13.0\end{array}$ & $\begin{array}{r}23.0 \\
8.5\end{array}$ & $\begin{array}{r}11.5 \\
6.0\end{array}$ & $\begin{array}{l}5.2 \\
4.5\end{array}$ & $\begin{array}{l}2.4 \\
3.5\end{array}$ & $\begin{array}{l}1.0 \\
2.8\end{array}$ & $\begin{array}{r}.4 \\
2.3\end{array}$ \\
\hline
\end{tabular}


Table 7. Mean monthly discharge for streamflow-measurement sites (1938-82 base period)

\begin{tabular}{|c|c|c|c|c|c|c|c|c|c|c|c|c|c|}
\hline \multirow{2}{*}{$\begin{array}{l}\text { Site } \\
\text { No. }\end{array}$} & \multirow{2}{*}{$\begin{array}{l}\text { Stream name } \\
\text { and gaging } \\
\text { station number }\end{array}$} & \multicolumn{6}{|c|}{ Mean discharge, in cubi } & eet per & \multicolumn{4}{|c|}{ second, for indicated month } & \multirow[b]{2}{*}{ Sept. } \\
\hline & & Oct. & Nov. & Dec. & Jan. & Feb. & Mar. & Apr. & May & June & July & Aug. & \\
\hline 1 & $\begin{array}{l}\text { Young Creek below } \\
\text { South Fork. }\end{array}$ & 6.7 & 6.6 & 6.4 & 5.3 & 5.5 & 7.1 & 22.1 & 48.4 & 41.7 & 17.4 & 6.8 & 6.4 \\
\hline 2 & $\begin{array}{l}\text { Young Creek at } \\
\text { mouth. }\end{array}$ & 6.6 & 6.4 & 6.1 & 5.2 & 5.3 & 6.8 & 21.4 & 46.8 & 40.3 & 16.8 & 6.7 & 6.2 \\
\hline 3 & $\begin{array}{c}\text { Cayuse Creek } \\
(12300400) .\end{array}$ & 1.4 & 1.5 & 1.6 & 1.4 & 1.5 & 2.6 & 20.0 & 34.1 & 9.9 & 2.6 & 1.2 & 0.9 \\
\hline 4 & $\begin{array}{l}\text { Fortine Creek } \\
(12300500) .\end{array}$ & 17.0 & 19.0 & 20.0 & 17.0 & 18.0 & 33.0 & 248.0 & 424.0 & 123.0 & 33.0 & 15.0 & 11.0 \\
\hline 5 & Deep Creek & 1.5 & 1.7 & 2.9 & 2.3 & 2.8 & 4.1 & 22.0 & 70.5 & 37.5 & 4.7 & 1.6 & 1.2 \\
\hline $\begin{array}{l}7 \\
8 \\
9\end{array}$ & $\begin{array}{l}\text { Sullivan Creek } \\
\text { Boulder Creek } \\
\text { Big Creek near } \\
\text { Rexford } \\
(12301810) \text {. }\end{array}$ & $\begin{array}{r}4.5 \\
8.6 \\
18.0\end{array}$ & $\begin{array}{r}4.4 \\
8.4 \\
20.0\end{array}$ & $\begin{array}{r}4.3 \\
8.2 \\
34.0\end{array}$ & $\begin{array}{r}3.4 \\
6.8 \\
27.0\end{array}$ & $\begin{array}{r}3.7 \\
7.1 \\
33.0\end{array}$ & $\begin{array}{r}4.8 \\
9.1 \\
47.0\end{array}$ & $\begin{array}{r}14.9 \\
28.5 \\
256.0\end{array}$ & $\begin{array}{r}32.6 \\
62.4 \\
822.0\end{array}$ & $\begin{array}{r}28.0 \\
53.6 \\
437.0\end{array}$ & $\begin{array}{l}11.7 \\
22.4 \\
55.0\end{array}$ & $\begin{array}{r}4.6 \\
8.7 \\
19.0\end{array}$ & $\begin{array}{r}4.3 \\
8.2 \\
14.0\end{array}$ \\
\hline $\begin{array}{l}10 \\
15\end{array}$ & $\begin{array}{l}\text { Bristow Creek } \\
\text { Parmenter Creek }\end{array}$ & $\begin{array}{r}4.0 \\
.3\end{array}$ & $\begin{array}{l}4.5 \\
1.2\end{array}$ & $\begin{array}{r}2.0 \\
.3\end{array}$ & $\begin{array}{l}1.0 \\
1.8\end{array}$ & $\begin{array}{l}1.0 \\
1.6\end{array}$ & $\begin{array}{r}2.0 \\
19.4\end{array}$ & $\begin{array}{r}5.0 \\
31.2\end{array}$ & $\begin{array}{l}10.0 \\
81.7\end{array}$ & $\begin{array}{l}45.0 \\
96.4\end{array}$ & $\begin{array}{l}13.0 \\
37.3\end{array}$ & $\begin{array}{l}5.0 \\
1.7\end{array}$ & $\begin{array}{l}4.0 \\
1.0\end{array}$ \\
\hline $\begin{array}{l}16 \\
17 \\
18\end{array}$ & $\begin{array}{l}\text { Cedar Creek } \\
\text { Quartz Creek } \\
\text { Camp Creek } \\
\quad(12303440) .\end{array}$ & $\begin{array}{r}8.7 \\
25.2 \\
3.9\end{array}$ & $\begin{array}{r}9.6 \\
27.7 \\
3.5\end{array}$ & $\begin{array}{r}10.6 \\
30.9 \\
5.4\end{array}$ & $\begin{array}{r}7.8 \\
22.7 \\
8.0\end{array}$ & $\begin{array}{r}8.7 \\
25.2 \\
8.8\end{array}$ & $\begin{array}{r}7.8 \\
22.7 \\
11.4\end{array}$ & $\begin{array}{l}27.2 \\
78.9 \\
13.9\end{array}$ & & $\begin{array}{r}80.2 \\
233.0 \\
65.7\end{array}$ & 5 & $\begin{array}{r}7.8 \\
22.7 \\
4.5\end{array}$ & $\begin{array}{r}6.9 \\
20.1 \\
3.5\end{array}$ \\
\hline $\begin{array}{l}19 \\
20\end{array}$ & $\begin{array}{l}\text { Ruby Creek } \\
\text { Pete Creek below } \\
\text { Hensley Creek. }\end{array}$ & $\begin{array}{l}4.7 \\
6.1\end{array}$ & $\begin{array}{l}4.9 \\
6.3\end{array}$ & $\begin{array}{r}6.3 \\
13.1\end{array}$ & $\begin{array}{r}6.3 \\
10.6\end{array}$ & $\begin{array}{r}9.3 \\
12.2\end{array}$ & $\begin{array}{l}41.0 \\
26.1\end{array}$ & $\begin{array}{l}71.7 \\
75.2\end{array}$ & & $\begin{array}{l}55.4 \\
77.3\end{array}$ & & 5,3 & $\begin{array}{l}4.9 \\
6.7\end{array}$ \\
\hline 21 & $\begin{array}{l}\text { Pete Creek at } \\
\text { mouth. }\end{array}$ & 7.0 & 7.2 & 14.8 & 12.0 & 14.0 & 29.7 & 85.4 & 177.0 & 87.7 & 22.2 & 8.8 & .7 \\
\hline 22 & $\begin{array}{l}\text { Whitetail Creek } \\
(12304250) \text {. }\end{array}$ & .0 & .0 & .0 & .4 & .5 & 2.9 & 5.3 & 7.6 & 3.7 & .5 & .0 & .0 \\
\hline $\begin{array}{l}23 \\
24\end{array}$ & $\begin{array}{l}\text { Spread Creek } \\
\text { Hell roaring Creek } \\
\text { at Forest }\end{array}$ & $\begin{array}{r}23.7 \\
7.9\end{array}$ & $\begin{array}{r}24.5 \\
8.2\end{array}$ & $\begin{array}{l}30.3 \\
10.1\end{array}$ & $\begin{array}{r}24.6 \\
8.2\end{array}$ & $\begin{array}{r}28.3 \\
9.6\end{array}$ & $\begin{array}{l}41.8 \\
14.0\end{array}$ & $\begin{array}{r}174.0 \\
58.3\end{array}$ & & $\begin{array}{r}179.0 \\
59.9\end{array}$ & $\begin{array}{l}45.5 \\
15.2\end{array}$ & $\begin{array}{r}18.0 \\
6.0\end{array}$ & $\begin{array}{r}15.7 \\
5.3\end{array}$ \\
\hline 25 & $\begin{array}{l}\text { Service Bridge. } \\
\text { Hellroaring Creek } \\
\text { at mouth. }\end{array}$ & 8.1 & 8.4 & 10.4 & 8.4 & 9.7 & 14.3 & 59.8 & 125.0 & 61.5 & 15.6 & 6.2 & 5.4 \\
\hline 26 & $\begin{array}{l}\text { North Fork Meadow } \\
\text { Creek. }\end{array}$ & 4 & 4 & 52 & 4 & 48 & 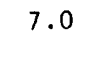 & 29.4 & 0 & 0.3 & 7 & 3.1 & $i$ \\
\hline 27 & $\begin{array}{l}\text { North Fork Meadow } \\
\text { Creek at mouth. }\end{array}$ & 3.9 & 4.0 & 5.1 & 4.1 & 4.7 & 6.9 & 28.8 & 59.7 & 29.6 & 7.5 & 0 & $2 . \epsilon$ \\
\hline $\begin{array}{l}28 \\
29 \\
30\end{array}$ & $\begin{array}{l}\text { Meadow Creek } \\
\text { Red Top Creek } \\
\text { Cyclone Creek } \\
(12304300) .\end{array}$ & $\begin{array}{r}12.5 \\
5.8 \\
3.1\end{array}$ & $\begin{array}{r}12.9 \\
6.0 \\
3.2\end{array}$ & $\begin{array}{r}16.0 \\
7.4 \\
4.0\end{array}$ & $\begin{array}{r}13.0 \\
6.0 \\
3.3\end{array}$ & $\begin{array}{r}15.0 \\
6.9 \\
3.8\end{array}$ & $\begin{array}{r}22 \\
10 \\
5\end{array}$ & & $\begin{array}{l}8 \\
4\end{array}$ & $\begin{array}{l}94.6 \\
43.9 \\
23.8\end{array}$ & & $\begin{array}{l}5 \\
4 \\
4 \\
4\end{array}$ & $\begin{array}{l}8 . \bar{\varepsilon} \\
3 . \bar{\varepsilon} \\
2.2\end{array}$ \\
\hline 31 & $\begin{array}{l}\text { Fourth of July } \\
\text { Creek }(12304400) .\end{array}$ & 3.9 & 4.0 & 4.9 & 4.0 & 4.6 & 6.8 & 28.5 & 58.8 & 29.3 & 7.4 & 2.9 & 2.6 \\
\hline 40 & $\begin{array}{l}\text { Deer Creek } \\
(12339300)\end{array}$ & 5.1 & 5.4 & 4.7 & 4.7 & 4.7 & 5.7 & 24.9 & 75.5 & 82.3 & 24.4 & 9.0 & 6.2 \\
\hline $\begin{array}{l}41 \\
42\end{array}$ & $\begin{array}{l}\text { Seeley Creek } \\
\text { West Twin Creek } \\
(12339900) \text {. }\end{array}$ & 2.0 & 2.0 & 2.5 & 2.0 & 2.0 & & $\begin{array}{r}4 . \\
13\end{array}$ & & $\begin{array}{r}6.0 \\
44.3\end{array}$ & 2. & & $\begin{array}{l}2.0 \\
3.3\end{array}$ \\
\hline 44 & $\begin{array}{l}\text { Marshal1 Creek } \\
(12340200) .\end{array}$ & 1.8 & 1.1 & 1.1 & 1.3 & 1.6 & 2.4 & 4.8 & 8.7 & 1.7 & 1.4 & .9 & .7 \\
\hline $\begin{array}{l}47 \\
48\end{array}$ & $\begin{array}{l}\text { Tin Cup Creek } \\
\text { Burke Gulch } \\
(12344300) .\end{array}$ & $\begin{array}{r}38.6 \\
.7\end{array}$ & $\begin{array}{r}33.2 \\
.7\end{array}$ & $\begin{array}{r}28.9 \\
.6\end{array}$ & $\begin{array}{r}25.7 \\
.4\end{array}$ & $\begin{array}{r}26.1 \\
.4\end{array}$ & $\begin{array}{r}34.3 \\
.5\end{array}$ & 98.5 & 305.0 & $\begin{array}{r}328.0 \\
7.8\end{array}$ & $\begin{array}{r}104.0 \\
2.7\end{array}$ & $\begin{array}{r}36.4 \\
.6\end{array}$ & $\begin{array}{r}33.2 \\
.4\end{array}$ \\
\hline $\begin{array}{l}49 \\
50\end{array}$ & $\begin{array}{l}\text { Lost Horse Creek } \\
\text { Camas Creek } \\
(12345800) \text {. }\end{array}$ & $\begin{array}{r}76.1 \\
5.4\end{array}$ & $\begin{array}{r}64.7 \\
5.2\end{array}$ & $\begin{array}{r}60.4 \\
4.6\end{array}$ & $\begin{array}{r}38.0 \\
3.0\end{array}$ & $\begin{array}{r}32.2 \\
3.2\end{array}$ & $\begin{array}{r}47.0 \\
3.9\end{array}$ & $\begin{array}{r}208.0 \\
16.1\end{array}$ & $\begin{array}{r}682.0 \\
53.0\end{array}$ & $\begin{array}{r}740.0 \\
59.2\end{array}$ & $\begin{array}{r}253.0 \\
20.9\end{array}$ & $\begin{array}{r}38.0 \\
4.6\end{array}$ & $\begin{array}{r}27.7 \\
3.3\end{array}$ \\
\hline 51 & $\begin{array}{l}\text { Sleeping Child } \\
\text { Creek (12345850). }\end{array}$ & 24.8 & 21.4 & 18.6 & 16.5 & 16.8 & 22.1 & 63.5 & 197.0 & 211.0 & 66.9 & 23.5 & 21.4 \\
\hline 52 & $\begin{array}{l}\text { Little Sleeping } \\
\text { Child Creek. }\end{array}$ & 1 & 1 & 1 & 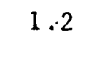 & 2 & , & 5.8 & 1 & .0 & 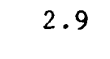 & 1.6 & 1.6 \\
\hline 53 & $\begin{array}{l}\text { Roaring Lion } \\
\text { Creek. }\end{array}$ & 2 & 21. & 2 & 1 & .8 & 15.7 & 9.5 & 28.0 & 248.0 & 84.5 & 12.7 & 9.3 \\
\hline $\begin{array}{l}54 \\
56 \\
58\end{array}$ & $\begin{array}{l}\text { Sawtooth Creek } \\
\text { Gird Creek } \\
\text { Mill Creek }\end{array}$ & $\begin{array}{r}24.1 \\
7.0 \\
20.1\end{array}$ & $\begin{array}{r}20.5 \\
6.2 \\
17.1\end{array}$ & $\begin{array}{r}19.2 \\
5.0 \\
16.0\end{array}$ & $\begin{array}{r}12.1 \\
4.2 \\
10.1\end{array}$ & $\begin{array}{r}10.2 \\
4.9 \\
8.5\end{array}$ & $\begin{array}{r}14.9 \\
4.8 \\
12.4\end{array}$ & $\begin{array}{l}66.1 \\
10.3 \\
55.1\end{array}$ & $\begin{array}{r}216.0 \\
46.8 \\
181.0\end{array}$ & $\begin{array}{r}235.0 \\
71.8 \\
196.0\end{array}$ & $\begin{array}{l}80.2 \\
25.8 \\
66.9\end{array}$ & $\begin{array}{r}12.1 \\
9.8 \\
10.1\end{array}$ & $\begin{array}{l}8.8 \\
7.2 \\
7.3\end{array}$ \\
\hline
\end{tabular}


Table 7. Mean monthly discharge for streamflow-measurement sites (1938-82 base period)-Continued

\begin{tabular}{|c|c|c|c|c|c|c|c|c|c|c|c|c|c|}
\hline \multirow[b]{2}{*}{$\begin{array}{l}\text { Site } \\
\text { No. }\end{array}$} & \multirow{2}{*}{$\begin{array}{l}\text { Stream name } \\
\text { and gaging } \\
\text { station number }\end{array}$} & \multicolumn{12}{|c|}{ Mean discharge, in cubic feet per second, for indicated month } \\
\hline & & Oct. & - Nov. & - Dec. & - Jan. & Feb. & - Mar. & Apr. & May & June & July & Aug. & Sept. \\
\hline 60 & $\begin{array}{l}\text { Sweat House } \\
\text { Creek. }\end{array}$ & 10.1 & 8.6 & 8.0 & 5.1 & 4.3 & 6.2 & 27.7 & 91.0 & 98.6 & 33.6 & 5.1 & 3.7 \\
\hline 61 & $\begin{array}{l}\text { Gash Creek } \\
(12350200)\end{array}$ & 4.3 & 3.6 & 3.4 & 2.2 & 1.8 & 2.6 & 11.7 & 38.5 & 41.7 & 14.2 & 2.2 & 1.6 \\
\hline $\begin{array}{l}62 \\
65 \\
66\end{array}$ & $\begin{array}{l}\text { Big Creek } \\
\text { Bass Creek } \\
\text { Sweeney Creek }\end{array}$ & $\begin{array}{l}39.5 \\
10.9 \\
12.4\end{array}$ & $\begin{array}{l}34.0 \\
11.0 \\
12.4\end{array}$ & $\begin{array}{l}29.7 \\
10.3 \\
11.7\end{array}$ & $\begin{array}{r}26.4 \\
9.3 \\
10.6\end{array}$ & $\begin{array}{r}26.8 \\
9.3 \\
10.5\end{array}$ & $\begin{array}{r}35.2 \\
9.6 \\
11.0\end{array}$ & $\begin{array}{r}101.0 \\
21.3 \\
24.1\end{array}$ & $\begin{array}{r}313.0 \\
74.9 \\
85.0\end{array}$ & $\begin{array}{l}336.0 \\
104.0 \\
118.0\end{array}$ & $\begin{array}{r}107.0 \\
39.2 \\
44.5\end{array}$ & $\begin{array}{l}37.4 \\
17.4 \\
19.7\end{array}$ & $\begin{array}{l}34.0 \\
10.6 \\
13.6\end{array}$ \\
\hline $\begin{array}{l}69 \\
71\end{array}$ & $\begin{array}{l}\text { Butler Creek } \\
\text { Twelvemile } \\
\text { Creek. }\end{array}$ & $\begin{array}{r}2.9 \\
10.5\end{array}$ & $\begin{array}{r}3.2 \\
12.9\end{array}$ & $\begin{array}{r}3.5 \\
22.9\end{array}$ & $\begin{array}{r}3.6 \\
20.0\end{array}$ & $\begin{array}{r}4.3 \\
24.4\end{array}$ & $\begin{array}{r}7.4 \\
33.4\end{array}$ & $\begin{array}{l}27.1 \\
90.0\end{array}$ & $\begin{array}{r}44.1 \\
160.0\end{array}$ & $\begin{array}{r}30.5 \\
104.0\end{array}$ & $\begin{array}{r}9.4 \\
29.3\end{array}$ & $\begin{array}{r}3.5 \\
15.6\end{array}$ & $\begin{array}{r}3.2 \\
11.5\end{array}$ \\
\hline $\begin{array}{l}72 \\
73 \\
74\end{array}$ & $\begin{array}{l}\text { Ward Creek } \\
\text { Twomile Creek } \\
\text { St. Regis } \\
\text { River } \\
\text { (12354000). }\end{array}$ & $\begin{array}{r}9.6 \\
5.4 \\
143.0\end{array}$ & $\begin{array}{r}11.9 \\
6.7 \\
191.0\end{array}$ & $\begin{array}{r}21.2 \\
11.9 \\
254.0\end{array}$ & $\begin{array}{r}18.3 \\
10.3 \\
213.0\end{array}$ & $\begin{array}{r}22.4 \\
12.6 \\
245.0\end{array}$ & $\begin{array}{r}30.8 \\
17.3 \\
347.0\end{array}$ & $\begin{array}{r}83.0 \\
46.7 \\
1,108.0\end{array}$ & $\begin{array}{r}147.0 \\
82.6 \\
2,099.0\end{array}$ & $\begin{array}{r}96.0 \\
54.0 \\
1,278.0\end{array}$ & $\begin{array}{r}27.0 \\
15.2 \\
341.0\end{array}$ & $\begin{array}{r}14.4 \\
8.1 \\
152.0\end{array}$ & $\begin{array}{r}10.5 \\
5.9 \\
119.0\end{array}$ \\
\hline $\begin{array}{l}75 \\
77\end{array}$ & $\begin{array}{c}\text { Siegel Creek } \\
\text { Bear Creek } \\
(12356500) .\end{array}$ & $\begin{array}{r}2.5 \\
16.0\end{array}$ & $\begin{array}{r}3.1 \\
14.0\end{array}$ & $\begin{array}{r}5.4 \\
11.0\end{array}$ & $\begin{array}{r}4.7 \\
10.0\end{array}$ & $\begin{array}{l}5.8 \\
8.0\end{array}$ & $\begin{array}{r}7.9 \\
10.0\end{array}$ & $\begin{array}{l}21.3 \\
46.0\end{array}$ & $\begin{array}{r}37.7 \\
191.0\end{array}$ & $\begin{array}{r}24.6 \\
143.0\end{array}$ & $\begin{array}{r}6.9 \\
37.0\end{array}$ & $\begin{array}{r}3.7 \\
17.0\end{array}$ & $\begin{array}{r}2.7 \\
13.0\end{array}$ \\
\hline $\begin{array}{l}79 \\
85 \\
86\end{array}$ & $\begin{array}{l}\text { Fish Creek } \\
\text { Piper Creek } \\
\text { Goat Creek } \\
\text { above Scout } \\
\text { Creek. }\end{array}$ & $\begin{array}{r}14.0 \\
5.4 \\
.3\end{array}$ & $\begin{array}{r}15.0 \\
5.7 \\
.3\end{array}$ & $\begin{array}{r}11.0 \\
4.9 \\
.3\end{array}$ & $\begin{array}{r}11.0 \\
4.9 \\
.2\end{array}$ & $\begin{array}{r}9.0 \\
4.9 \\
.2\end{array}$ & $\begin{array}{r}8.0 \\
6.0 \\
.9\end{array}$ & $\begin{array}{r}12.0 \\
26.2 \\
.9\end{array}$ & $\begin{array}{r}110.0 \\
79.4 \\
60.6\end{array}$ & $\begin{array}{l}60.0 \\
86.6 \\
89.4\end{array}$ & & $\begin{array}{r}15.0 \\
9.5 \\
1.7\end{array}$ & $\begin{array}{r}10.0 \\
6.5 \\
.4\end{array}$ \\
\hline 87 & $\begin{array}{l}\text { Goat Creek } \\
\text { above Squeezer } \\
\text { Creek Road. }\end{array}$ & 5.8 & 6.0 & 5.2 & 4.9 & 5.1 & 5.2 & 20.9 & 95.6 & 112.0 & 20.8 & 7.2 & 6.0 \\
\hline 88 & $\begin{array}{l}\text { Goat Creek at } \\
\text { Squeezer } \\
\text { Creek Road. }\end{array}$ & 5.7 & 5.9 & 5.1 & 4.8 & 5.0 & 5.1 & 20.6 & 94.0 & 110.0 & 20.5 & 7.1 & 5.9 \\
\hline 89 & $\begin{array}{l}\text { South Woodward } \\
\text { Creek above } \\
\text { Fatty Creek } \\
\text { Road. }\end{array}$ & 5.1 & 5.3 & 5.1 & 3.7 & 4.4 & 4.3 & 6.4 & 10.2 & 11.3 & 7.3 & 5.8 & 5.3 \\
\hline 90 & $\begin{array}{l}\text { South Woodward } \\
\text { Creek near } \\
\text { mouth. }\end{array}$ & 26.7 & 24.5 & 23.7 & 20.8 & 19.7 & 17.8 & 18.4 & 29.7 & 38.6 & 29.7 & 29.7 & 30.7 \\
\hline 91 & $\begin{array}{l}\text { Soup Creek } \\
\text { above Soup } \\
\text { Creek Camp- } \\
\text { ground. }\end{array}$ & 3.0 & 3.1 & 2.7 & 2.7 & 2.7 & 3.3 & 14.4 & 43.8 & 47.8 & 14.1 & 5.2 & 3.6 \\
\hline 92 & $\begin{array}{l}\text { Soup Creek at } \\
\text { Soup Creek } \\
\text { Campground. }\end{array}$ & 2.8 & 2.9 & 2.5 & 2.5 & 2.5 & 3.0 & 13.2 & 40.2 & 43.8 & 13.0 & 4.7 & 3.3 \\
\hline 93 & $\begin{array}{l}\text { Soup Creek at } \\
\text { Highway } 83 \text {. }\end{array}$ & 3.5 & 3.6 & 3.1 & 3.1 & 3.1 & 3.8 & 16.5 & 50.3 & 54.8 & 16.2 & 5.9 & 4.1 \\
\hline 94 & $\begin{array}{l}\text { South Fork } \\
\text { Lost Creek. }\end{array}$ & 10.6 & 11.0 & 9.6 & 9.6 & 9.5 & 16.7 & 57.4 & 145.0 & 153.0 & 55.6 & 22.7 & 13.0 \\
\hline 95 & $\begin{array}{l}\text { North Fork } \\
\text { Lost Creek. }\end{array}$ & 7.5 & 7.8 & 6.8 & 6.8 & 6.8 & 8.3 & 36.2 & 110.0 & 120.0 & 35.5 & 13.1 & 9.1 \\
\hline 96 & Lost Creek & 15.0 & 15.6 & 13.6 & 13.6 & 13.6 & 16.6 & 72.5 & 220.0 & 240.0 & 71.1 & 26.2 & 18.2 \\
\hline $\begin{array}{r}97 \\
98 \\
99 \\
100 \\
102\end{array}$ & $\begin{array}{l}\text { Porcupine Creek } \\
\text { Bond Creek } \\
\text { Hall Creek } \\
\text { Johnson Creek } \\
\text { Stoner Creek }\end{array}$ & $\begin{array}{l}2.5 \\
1.5 \\
4.0 \\
3.0 \\
5.0\end{array}$ & $\begin{array}{l}2.2 \\
1.6 \\
3.5 \\
2.5 \\
5.0\end{array}$ & $\begin{array}{l}1.8 \\
1.5 \\
3.0 \\
1.8 \\
5.0\end{array}$ & $\begin{array}{l}1.4 \\
1.5 \\
3.0 \\
1.0 \\
4.0\end{array}$ & $\begin{array}{l}1.2 \\
1.7 \\
3.0 \\
.8 \\
4.0\end{array}$ & $\begin{array}{l}2.8 \\
4.5 \\
3.5 \\
1.0 \\
5.0\end{array}$ & $\begin{array}{r}3.7 \\
8.6 \\
15.0 \\
10.0 \\
10.0\end{array}$ & $\begin{array}{l}8.8 \\
49.7 \\
55.0 \\
20.0 \\
34.0\end{array}$ & $\begin{array}{l}2.9 \\
62.3 \\
28.0 \\
20.0 \\
50.0\end{array}$ & $\begin{array}{l}2.8 \\
15.1 \\
16.0 \\
10.0 \\
15.0\end{array}$ & $\begin{array}{r}2.8 \\
3.0 \\
12.0 \\
4.0 \\
4.0\end{array}$ & $\begin{array}{l}2.9 \\
2.3 \\
5.0 \\
3.0 \\
2.0\end{array}$ \\
\hline $\begin{array}{l}105 \\
106\end{array}$ & $\begin{array}{l}\text { Graves Creek } \\
\text { Deep Creek }\end{array}$ & $\begin{array}{r}10.1 \\
4.3\end{array}$ & $\begin{array}{l}5.2 \\
5.3\end{array}$ & $\begin{array}{l}2.5 \\
9.4\end{array}$ & $\begin{array}{l}2.5 \\
8.2\end{array}$ & $\begin{array}{r}2.8 \\
10.0\end{array}$ & $\begin{array}{l}12.6 \\
13.7\end{array}$ & $\begin{array}{l}20.9 \\
36.9\end{array}$ & $\begin{array}{r}172.0 \\
65.4\end{array}$ & $\begin{array}{r}177.0 \\
42.7\end{array}$ & $\begin{array}{l}70.7 \\
12.0\end{array}$ & $\begin{array}{r}25.3 \\
6.4\end{array}$ & $\begin{array}{r}10.4 \\
4.7\end{array}$ \\
\hline
\end{tabular}


Table 8. Basin characteristics and mean annual discharge for streamflow-gaging stations (1938-82 base period) $\left[\mathrm{mi}^{2}\right.$, square miles; $\mathrm{ft}^{3} / \mathrm{s}$, cubic feet per second]

\begin{tabular}{|c|c|c|c|c|c|c|}
\hline $\begin{array}{l}\text { Site } \\
\text { No. }\end{array}$ & $\begin{array}{l}\text { Stream name and gaging } \\
\text { station number }\end{array}$ & $\begin{array}{l}\text { Number } \\
\text { of } \\
\text { years } \\
\text { of } \\
\text { record }\end{array}$ & $\begin{array}{l}\text { Drainge } \\
\text { area } \\
\left(m i^{2}\right)\end{array}$ & $\begin{array}{l}\text { Mean } \\
\text { annual } \\
\text { precip- } \\
\text { itation } \\
\text { (inches) }\end{array}$ & $\begin{array}{l}\text { Mean } \\
\text { annual } \\
\text { dis- } \\
\text { charge } \\
\left(\mathrm{ft}^{3} / \mathrm{s}\right)\end{array}$ & $\begin{array}{l}\text { Mean } \\
\text { annual } \\
\text { runoff } \\
\text { (inches) }\end{array}$ \\
\hline $\begin{array}{r}6 \\
11 \\
12\end{array}$ & $\begin{array}{l}\text { Tobacco River (12301300) } \\
\text { Wolf Creek near Libby (12301999) } \\
\text { Fisher River near } \\
\text { Jennings }(12302000) \text {. }\end{array}$ & $\begin{array}{l}24 \\
10 \\
18\end{array}$ & $\begin{array}{l}440 \\
216 \\
780\end{array}$ & $\begin{array}{l}31 \\
27 \\
32\end{array}$ & $\begin{array}{l}268 \\
67.0 \\
510\end{array}$ & $\begin{array}{l}8.3 \\
4.2 \\
8.9\end{array}$ \\
\hline $\begin{array}{l}13 \\
14\end{array}$ & $\begin{array}{l}\text { Granite Creek }(12302500) \\
\text { Flower Creek }(12303100)\end{array}$ & $\begin{array}{l}16 \\
22\end{array}$ & $\begin{array}{l}23.6 \\
11.1\end{array}$ & $\begin{array}{l}67 \\
67\end{array}$ & $\begin{array}{l}71.0 \\
27.0\end{array}$ & $\begin{array}{l}40.8 \\
33.0\end{array}$ \\
\hline $\begin{array}{l}32 \\
33 \\
34 \\
35 \\
36\end{array}$ & $\begin{array}{l}\text { Yaak River }(12304500) \\
\text { German Gulch }(12323500) \\
\text { Racetrack Creek }(12324100) \\
\text { Boulder Creek }(12330000) \\
\text { Middle Fork } \\
\text { Rock Creek (12332000). }\end{array}$ & $\begin{array}{l}26 \\
14 \\
16 \\
43 \\
45\end{array}$ & $\begin{array}{r}766 \\
40.6 \\
39.5 \\
71.3 \\
123\end{array}$ & $\begin{array}{l}43 \\
18 \\
35 \\
31 \\
35\end{array}$ & $\begin{array}{r}888 \\
21.0 \\
59.0 \\
48.0 \\
124\end{array}$ & $\begin{array}{r}15.7 \\
7.0 \\
20.3 \\
9.1 \\
13.6\end{array}$ \\
\hline 37 & $\begin{array}{l}\text { Blackfoot River near } \\
\text { Helmville }(12335000) \text {. }\end{array}$ & 13 & 481 & 15 & 342 & 9.6 \\
\hline $\begin{array}{l}38 \\
39 \\
43 \\
45\end{array}$ & $\begin{array}{l}\text { Nevada Creek }(12335500) \\
\text { Monture Creek }(12338690) \\
\text { Blackfoot River }(12340000) \\
\text { East Fork Bitterroot } \\
\text { River (1234300). }\end{array}$ & $\begin{array}{r}43 \\
9 \\
46 \\
16\end{array}$ & $\begin{array}{r}116 \\
140 \\
2,290 \\
381\end{array}$ & $\begin{array}{l}23 \\
35 \\
29 \\
32\end{array}$ & $\begin{array}{r}38.0 \\
184 \\
1,629 \\
282\end{array}$ & $\begin{array}{r}4.4 \\
17.8 \\
9.7 \\
10.0\end{array}$ \\
\hline $\begin{array}{l}46 \\
55 \\
57 \\
59 \\
63\end{array}$ & $\begin{array}{l}\text { Bitterroot River (12344000) } \\
\text { Skalkaho Creek }(12346500) \\
\text { Blodgett Creek }(12347500) \\
\text { Bear Creek }(12350000) \\
\text { Kootenai Creek }(12350500)\end{array}$ & $\begin{array}{l}45 \\
26 \\
22 \\
18 \\
10\end{array}$ & $\begin{array}{r}1,049 \\
87.8 \\
26.4 \\
26.8 \\
28.9\end{array}$ & $\begin{array}{l}22 \\
36 \\
64 \\
63 \\
64\end{array}$ & $\begin{array}{r}934 \\
91.0 \\
68.0 \\
70.0 \\
78.0\end{array}$ & $\begin{array}{l}12.1 \\
14.1 \\
35.0 \\
35.4 \\
36.6\end{array}$ \\
\hline $\begin{array}{l}64 \\
67 \\
68\end{array}$ & $\begin{array}{l}\text { Burnt Fork Bitterroot (12351000) } \\
\text { Eightmile Creek }(12351400) \\
\text { Clark Fork below } \\
\text { Missoula (12353000). }\end{array}$ & $\begin{array}{r}24 \\
2 \\
53\end{array}$ & $\begin{array}{r}74.0 \\
20.6 \\
9,003.0\end{array}$ & $\begin{array}{l}32 \\
21 \\
17\end{array}$ & $\begin{array}{r}50.0 \\
8.0 \\
5,800\end{array}$ & $\begin{array}{l}9.2 \\
5.3 \\
8.7\end{array}$ \\
\hline $\begin{array}{l}70 \\
76\end{array}$ & $\begin{array}{l}\text { Ninemile Creek }(12353280) \\
\text { North Fork Flathead } \\
\text { River (12355500). }\end{array}$ & $\begin{array}{r}9 \\
53\end{array}$ & $\begin{array}{r}170.0 \\
1,548.0\end{array}$ & $\begin{array}{l}38 \\
26\end{array}$ & $\begin{array}{r}124 \\
3,050\end{array}$ & $\begin{array}{r}9.9 \\
26.7\end{array}$ \\
\hline 78 & $\begin{array}{l}\text { Middle Fork Flathead } \\
\text { River at Essex }(12357000) \text {. }\end{array}$ & 22 & 510.0 & 52 & 1,100 & 29.3 \\
\hline 80 & $\begin{array}{l}\text { South Fork Flathead } \\
\text { River above Twin Creek (12359800). }\end{array}$ & 17 & $1,160.0$ & 52 & 2,170 & 25.4 \\
\hline $\begin{array}{l}81 \\
82 \\
83\end{array}$ & $\begin{array}{l}\text { Twin Creek }(12360000) \\
\text { Suliivan Creek }(12361000) \\
\text { Graves Creek near } \\
\text { Hungry Horse }(12361500)\end{array}$ & $\begin{array}{l}11 \\
25 \\
11\end{array}$ & $\begin{array}{l}47.0 \\
71.3 \\
27.0\end{array}$ & $\begin{array}{l}53 \\
53 \\
67\end{array}$ & $\begin{array}{l}112 \\
210 \\
127\end{array}$ & $\begin{array}{l}32.3 \\
40.0 \\
63.8\end{array}$ \\
\hline 84 & $\begin{array}{l}\text { Swan River near } \\
\text { Condon }(12369200) .\end{array}$ & 10 & 69.1 & 54 & 160 & 31.4 \\
\hline 101 & $\begin{array}{l}\text { Swan River near } \\
\text { Big Fork }(12370000)\end{array}$ & 60 & 671.0 & 46 & 1,180 & 23.9 \\
\hline $\begin{array}{l}103 \\
104\end{array}$ & $\begin{array}{l}\text { Thompson River }(12389500) \\
\text { Prospect Creek }(12390700)\end{array}$ & $\begin{array}{l}26 \\
26\end{array}$ & $\begin{array}{l}642.0 \\
182.0\end{array}$ & $\begin{array}{l}41 \\
54\end{array}$ & $\begin{array}{l}480 \\
258\end{array}$ & $\begin{array}{l}10.1 \\
19.2\end{array}$ \\
\hline
\end{tabular}


Table 9. Discharge for various exceedance percentages for streamflow-gaging stations (1938-82 base period)

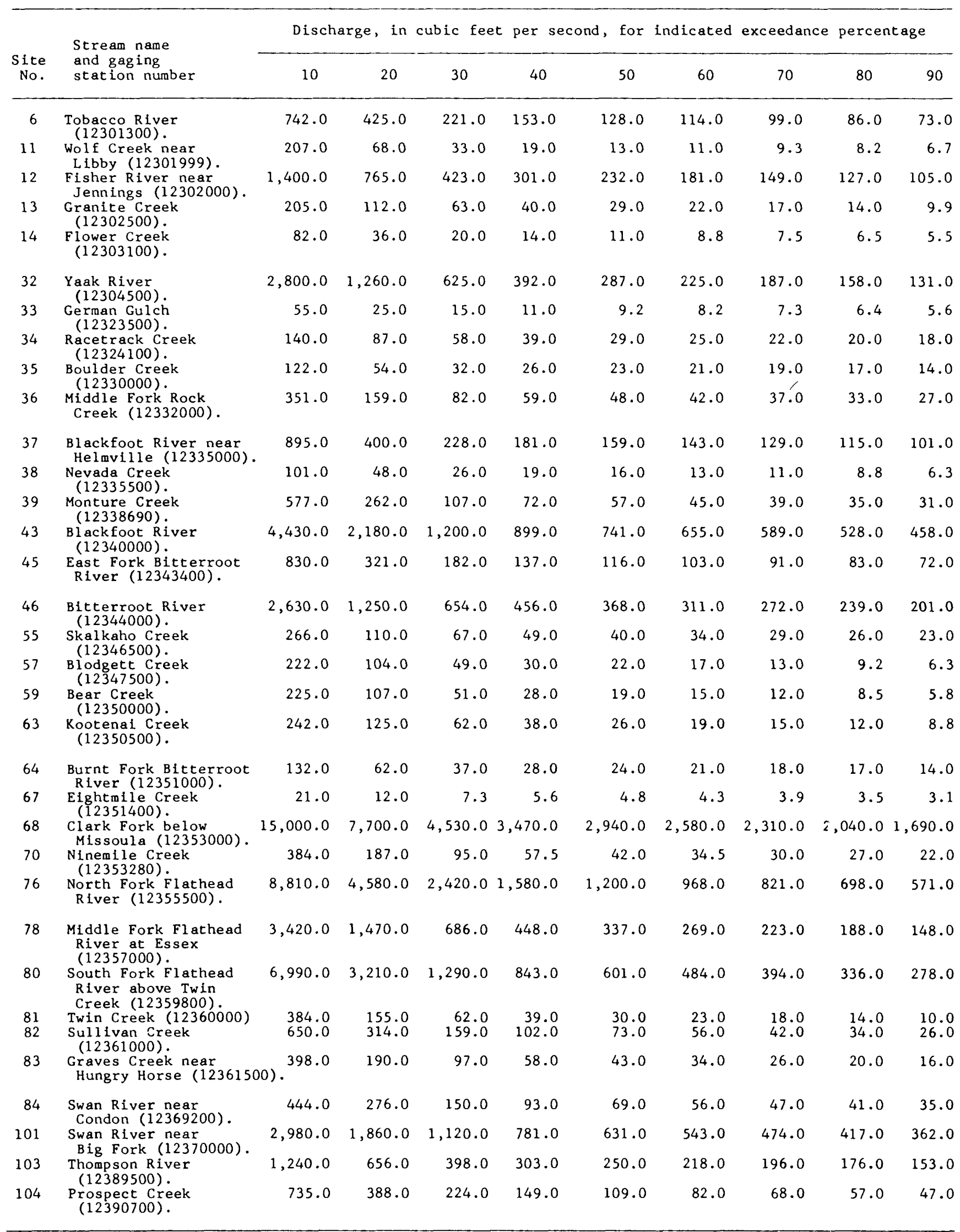


Table 10. Mean monthly discharge for streamflow-gaging stations (1938-82 base period)

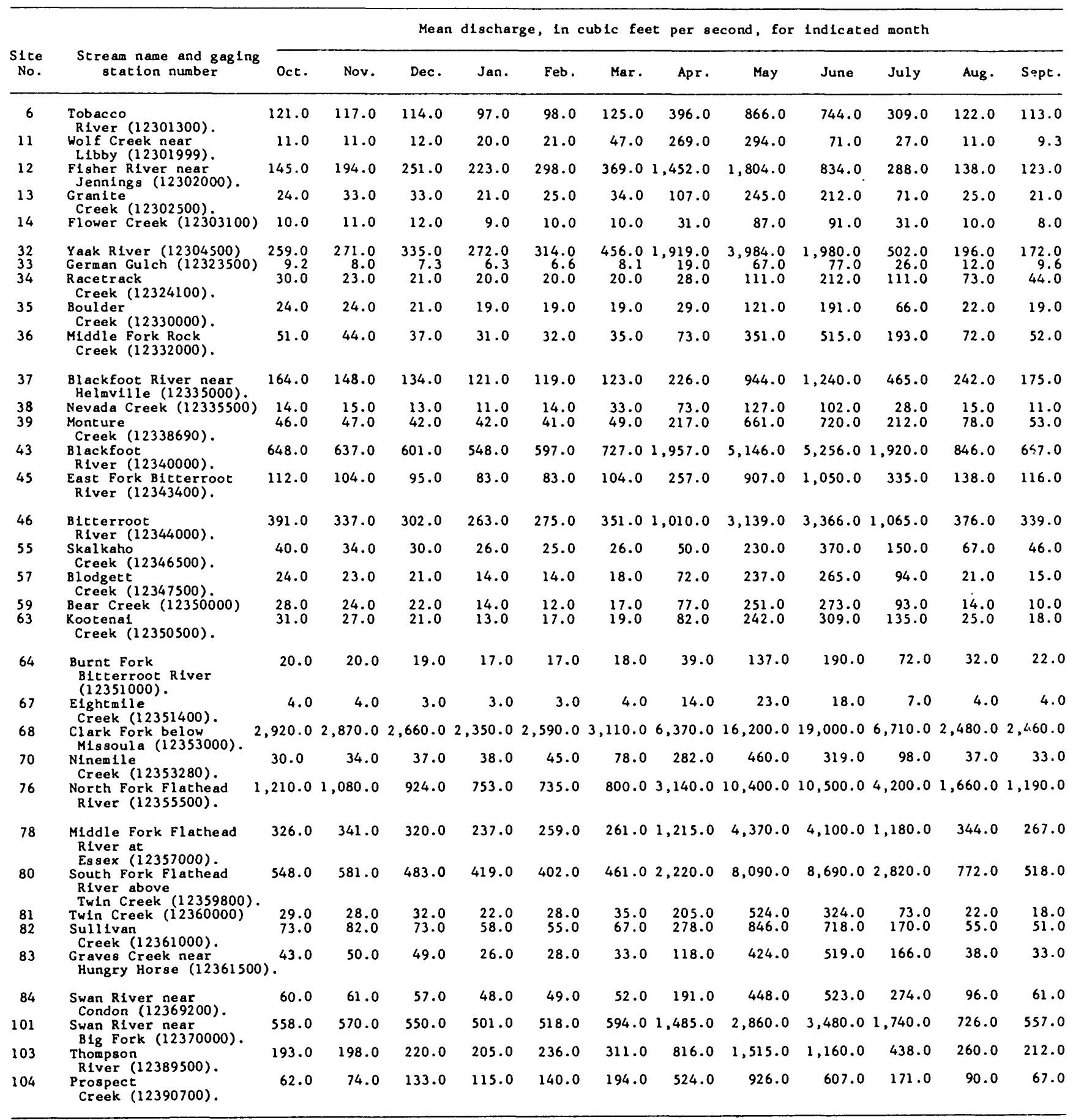


Table 11. Long-term mean annual discharge computation for Flower Creek near Libby (site 14) $\left[\mathrm{ft}^{3} / \mathrm{s}\right.$, cubic feet per second]

\begin{tabular}{|c|c|c|c|c|c|c|c|}
\hline \multirow[b]{2}{*}{ Date } & \multicolumn{3}{|c|}{ Yaak River } & \multicolumn{4}{|c|}{ Flower Creek } \\
\hline & $\begin{array}{c}\text { Daily } \\
\text { mean } \\
\text { discharge } \\
\left(\mathrm{ft}^{3} / \mathrm{s}\right)\end{array}$ & $\begin{array}{l}\text { Exceed- } \\
\text { ance } \\
\text { percent- } \\
\text { age }\end{array}$ & $\begin{array}{c}\text { Monthly } \\
\text { mean } \\
\text { discharge } \\
\left(\mathrm{ft}^{3} / \mathrm{s}\right)\end{array}$ & $\begin{array}{c}\text { Daily } \\
\text { nean } \\
\text { discharge } 2 \\
\left(\mathrm{ft}^{3} / \mathrm{s}\right)\end{array}$ & $\begin{array}{l}\text { Estimated } \\
\text { monthly } \\
\text { mean } \\
\text { discharge } \\
\left(\mathrm{ft}^{3} / \mathrm{s}\right)\end{array}$ & $\begin{array}{l}\text { Actual } \\
\text { monthly } \\
\text { mean } \\
\text { discharge } \\
\left(\mathrm{ft}^{3} / \mathrm{s}\right)\end{array}$ & $\begin{array}{l}\text { Percent } \\
\text { differ- } \\
\text { ence }\end{array}$ \\
\hline $10-15-80$ & 168 & 80 & 155 & 9.7 & 9.0 & 8.1 & +11 \\
\hline $11-15-80$ & 234 & 57 & 278 & 19 & 22.6 & 19.1 & +18 \\
\hline $12-15-80$ & 267 & 52 & 807 & 13 & 39.4 & 40.7 & -3 \\
\hline $01-15-81$ & 442 & 37 & 654 & 16 & 23.5 & 20.4 & +15 \\
\hline $02-15-81$ & 406 & 39 & 656 & 9.9 & 16.0 & 13.6 & +18 \\
\hline $03-15-81$ & 718 & 28 & 752 & 14 & 14.7 & 13.1 & +12 \\
\hline $04-15-81$ & 732 & 28 & 1,719 & 11 & 25.6 & 32.4 & -21 \\
\hline $05-15-81$ & 3,660 & 7.5 & 3,588 & 96 & $94 \cdot 1$ & 81.5 & +16 \\
\hline $06-15-81$ & 4,090 & 6.5 & 2,787 & 58 & 39.5 & 70.3 & -44 \\
\hline $07-15-81$ & 857 & 25 & 909 & 26 & 27.7 & 28.0 & -1 \\
\hline $08-15-81$ & 263 & 52 & 271 & 9.5 & 9.8 & 9.7 & +1 \\
\hline $09-15-81$ & 156 & 81 & 192 & 5.9 & 7.3 & 6.8 & +7 \\
\hline \multicolumn{3}{|c|}{$\begin{array}{c}\text { Annual mean discharge } \\
\text { (1981 water year) }\end{array}$} & 1,065 & & 27.6 & 28.7 & -4 \\
\hline \multicolumn{3}{|c|}{$\begin{array}{l}\text { Long-term mean annual } \\
\text { discharge (1938-82 } \\
\text { base period) }\end{array}$} & 888 & & ${ }^{3} 23.0$ & 27.0 & -15 \\
\hline
\end{tabular}

1 From Yaak River flow-duration curve.

2 Data used to prepare figure 7.

3 Determined from an average ratio of long-term mean annual discharge to annual mean discharge for 1981 at three nearby gaging stations. 
Table 12. Long-term mean annual discharge computation for Bear Creek near Victor (site 59)

\begin{tabular}{|c|c|c|c|c|c|c|c|}
\hline \multirow[b]{2}{*}{ Date } & \multicolumn{3}{|c|}{ Bitterroot River } & \multicolumn{4}{|c|}{ Bear Creek } \\
\hline & $\begin{array}{c}\text { Daily } \\
\text { mean } \\
\text { discharge } \\
\left(\mathrm{ft}^{3} / \mathrm{s}\right)\end{array}$ & $\begin{array}{l}\text { Exceed- } \\
\text { ance } \\
\text { percent- } \\
\text { age }\end{array}$ & $\begin{array}{c}\text { Monthly } \\
\text { mean } \\
\text { discharge } \\
\left(\mathrm{ft}^{3} / \mathrm{s}\right)\end{array}$ & $\begin{array}{l}\text { Dally } \\
\text { mean } \\
\text { discharge } 2 \\
\left(\mathrm{ft}^{3} / \mathrm{s}\right)\end{array}$ & $\begin{array}{l}\text { Estimated } \\
\text { monthly } \\
\text { mean } \\
\text { discharge } \\
\left(\mathrm{ft}^{3} / \mathrm{s}\right)\end{array}$ & $\begin{array}{l}\text { Actual } \\
\text { monthly } \\
\text { mean } \\
\text { discharge } \\
\left(\mathrm{ft}^{3} / \mathrm{s}\right)\end{array}$ & $\begin{array}{l}\text { Percent } \\
\text { d1ffer- } \\
\text { ence }\end{array}$ \\
\hline $10-15-58$ & 320 & 58 & 283 & 29 & 25.6 & 21.6 & +19 \\
\hline $11-15-58$ & 410 & 45 & 419 & 47 & 48.0 & 48.8 & -2 \\
\hline $12-15-58$ & 450 & 41 & 454 & 40 & 40.4 & 41.7 & -3 \\
\hline $01-15-59$ & 290 & 65 & 334 & 18 & 20.7 & 20.2 & +3 \\
\hline $02-15-59$ & 301 & 63 & 293 & 16 & 15.6 & 15.4 & +1 \\
\hline $03-15-59$ & 238 & 80 & 318 & 11 & 14.7 & 13.6 & +8 \\
\hline $04-15-59$ & 1,360 & 16 & 1,139 & 76 & 63.6 & 73.5 & -14 \\
\hline $05-15-59$ & 3,730 & 7.0 & 2,638 & 212 & 196 & 181 & +8 \\
\hline $06-15-59$ & 5,960 & 3.5 & 4,195 & 513 & 361 & 407 & -11 \\
\hline $07-15-59$ & 1,020 & 20 & 1,058 & 108 & 112 & 101 & +11 \\
\hline $08-15-59$ & 320 & 58 & 384 & 11 & 13.0 & 13.0 & 0 \\
\hline $09-15-59$ & 405 & 45 & 420 & 30 & 31.1 & 36.4 & -15 \\
\hline \multicolumn{3}{|c|}{$\begin{array}{c}\text { Annual mean discharge } \\
\text { (1959 water year) }\end{array}$} & 994 & & 78.5 & 80.9 & -3 \\
\hline \multicolumn{3}{|c|}{$\begin{array}{l}\text { Long-term mean annual } \\
\text { discharge (1938-82 } \\
\text { base period) }\end{array}$} & 934 & & ${ }^{3} 68.3$ & 70.0 & -2 \\
\hline
\end{tabular}

1 From Bitterroot River flow-duration curve.

2 Data used to prepare figure 8.

3 Determined from an average ratio of long-term mean annual discharge to annual mean discharge for 1959 at three nearby gaging stations. 
Table 13. Long-tern mean annual discharge computation for Swan River near Condon (site 84)

\begin{tabular}{|c|c|c|c|c|c|c|c|}
\hline \multirow[b]{2}{*}{ Date } & \multicolumn{3}{|c|}{ Monture Creek } & \multicolumn{4}{|c|}{ Swan River } \\
\hline & $\begin{array}{c}\text { Daily } \\
\text { mean } \\
\text { discharge } \\
\left(\mathrm{ft}^{3} / \mathrm{s}\right)\end{array}$ & $\begin{array}{l}\text { Exceed- } \\
\text { ance } \\
\text { percent- } \\
\text { age }\end{array}$ & $\begin{array}{l}\text { Monthly } \\
\text { nean } \\
\text { discharge } \\
\left(\mathrm{ft}^{3} / \mathrm{s}\right)\end{array}$ & $\begin{array}{l}\text { Daily } \\
\text { mean } \\
\text { discharge } \\
\left(\mathrm{ft}^{3} / \mathrm{s}\right)\end{array}$ & $\begin{array}{l}\text { Estimated } \\
\text { monthly } \\
\text { mean } \\
\text { discharge } \\
\left(\mathrm{ft}^{3} / \mathrm{s}\right)\end{array}$ & $\begin{array}{l}\text { Actual } \\
\text { monthly } \\
\text { mean } \\
\text { discharge } \\
\left(\mathrm{ft}^{3} / \mathrm{s}\right)\end{array}$ & $\begin{array}{l}\text { Percent } \\
\text { differ- } \\
\text { ence }\end{array}$ \\
\hline $10-15-80$ & 45 & 62 & 43.6 & 51 & 49.4 & 51.4 & -4 \\
\hline $11-15-80$ & 40 & 70 & 42.1 & 74 & 77.9 & 66.2 & +18 \\
\hline $12-15-80$ & 44 & 64 & 54.5 & 42 & 52.0 & 99.6 & -48 \\
\hline $01-15-81$ & 63 & 45 & 68.2 & 62 & 67.1 & 87.0 & -23 \\
\hline $02-15-81$ & 60 & 47 & 62.4 & 72 & 74.9 & 72.9 & +3 \\
\hline $03-15-81$ & 93 & 33 & 92.0 & 63 & 62.3 & 72.0 & -13 \\
\hline $04-15-81$ & 104 & 30 & 221 & 84 & 179 & 204 & -12 \\
\hline $05-15-81$ & 418 & 14 & 773 & 265 & 490 & 502 & -2 \\
\hline $06-15-81$ & 482 & 12 & 592 & 373 & 458 & 601 & -24 \\
\hline $07-15-81$ & 163 & 25 & 178 & 295 & 322 & 319 & +1 \\
\hline $08-15-81$ & 70 & 41 & 71.2 & 96 & 97.6 & 95.1 & +3 \\
\hline $09-15-81$ & 44 & 64 & 46.8 & 36 & 38.3 & 41.1 & -7 \\
\hline \multicolumn{3}{|c|}{$\begin{array}{l}\text { Annual mean discharge } \\
\text { (1981 water year) }\end{array}$} & 188 & & 165 & 185 & -11 \\
\hline \multicolumn{3}{|c|}{$\begin{array}{l}\text { Long-term mean annual } \\
\text { discharge ( } 1938-82 \\
\text { base period) }\end{array}$} & 184 & & ${ }^{3} 157$ & 160 & -2 \\
\hline
\end{tabular}

1 From Monture Creek flow-duration curve.

2 Data used to prepare figure 9.

3 Determined from an average ratio of annual mean discharge for 1981 to long-term mean annual discharge at three nearby gaging stations. 
Table 14. Estimated flow-duration curve error for Flower Creek near Libby (site 14)

\begin{tabular}{lccc}
\hline & $\begin{array}{c}\text { Daily mean discharge } \\
\text { of Flower Creek, in } \\
\text { cubic feet per second }\end{array}$ & \\
\hline $\begin{array}{l}\text { Excedance } \\
\text { percentage }\end{array}$ & $\begin{array}{c}\text { Estimated } \\
\text { Actual }\end{array}$ & $\begin{array}{c}\text { Percent } \\
\text { difference }\end{array}$ \\
\hline 90 & 4.9 & 5.5 & -11 \\
80 & 6.0 & 6.5 & -8 \\
70 & 7.1 & 7.5 & -5 \\
60 & 8.5 & 8.8 & -3 \\
50 & 10 & 11 & -9 \\
40 & 13 & 14 & -7 \\
30 & 19 & 20 & -5 \\
20 & 36 & 36 & -6 \\
10 & 75 & 82 & -9 \\
& & Average error & -6 \\
\hline
\end{tabular}

1 From figure 7.

Table 15. Estimated flow-duration curve error for Bear Creek near Victor (site 59)

\begin{tabular}{|c|c|c|c|}
\hline \multirow{2}{*}{$\begin{array}{l}\text { Exceedance } \\
\text { percentage }\end{array}$} & \multicolumn{2}{|c|}{$\begin{array}{l}\text { Dally mean discharge } \\
\text { of Bear Creek, in } \\
\text { cubic feet per second }\end{array}$} & \multirow{2}{*}{$\begin{array}{l}\text { Percent } \\
\text { difference }\end{array}$} \\
\hline & Estimated & Actual & \\
\hline 90 & 8.5 & 5.8 & +47 \\
\hline 80 & 11 & 8.5 & +29 \\
\hline 70 & 14 & 12 & +17 \\
\hline 60 & 18 & 15 & +20 \\
\hline 50 & 25 & 19 & +32 \\
\hline 40 & 35 & 28 & +25 \\
\hline 30 & 54 & 51 & +6 \\
\hline 20 & 94 & 107 & -12 \\
\hline \multirow[t]{2}{*}{10} & 200 & 225 & -11 \\
\hline & \multicolumn{2}{|c|}{ Average error } & $=\quad+17$ \\
\hline
\end{tabular}

I From figure 8. 
Table 16. Estimated flow-duration curve error for Swan River near Condon (site 84)

\begin{tabular}{lcccc}
\hline & \multicolumn{2}{c}{$\begin{array}{c}\text { Daily mean discharge } \\
\text { of Swan River, in } \\
\text { cubic feet per second }\end{array}$} & Percent \\
percentage & Estimated & Actual & difference \\
\hline 90 & 28 & 35 & -20 \\
80 & 33 & 41 & -20 \\
70 & 38 & 47 & -19 \\
60 & 45 & 56 & -20 \\
50 & 58 & 69 & -16 \\
40 & 80 & 93 & -14 \\
30 & 140 & 150 & -7 \\
20 & 240 & 276 & -13 \\
10 & 420 & 444 & -5 \\
\hline
\end{tabular}

1 From figure 9.

Table 17. Estimated long-term mean monthly discharges and errors for Flower Creek near Libby (site 14)

\begin{tabular}{|c|c|c|c|}
\hline \multirow[b]{2}{*}{ Month } & \multicolumn{2}{|c|}{$\begin{array}{l}\text { Long-term mean } \\
\text { monthly discharge of } \\
\text { Flower Creek, in } \\
\text { cubic feet per second }\end{array}$} & \multirow{2}{*}{$\begin{array}{l}\text { Percent } \\
\text { difference }\end{array}$} \\
\hline & Estimated & Actual & \\
\hline October & 9.5 & 10 & -5 \\
\hline November & 11 & 11 & 0 \\
\hline Decenber & 12 & 12 & 0 \\
\hline January & 7.6 & 9.0 & -16 \\
\hline February & 9.5 & 10 & -5 \\
\hline March & 12 & 10 & +20 \\
\hline Apr 11 & 44 & 31 & +42 \\
\hline May & 90 & 87 & +3 \\
\hline June & 80 & 91 & -12 \\
\hline July & 26 & 31 & -16 \\
\hline August & 7.9 & 10 & -21 \\
\hline September & 6.9 & 8.0 & -14 \\
\hline
\end{tabular}


Table 18. Estimated long-term mean monthly discharges and errors for Bear Creek near Victor (site 59)

\begin{tabular}{|c|c|c|c|}
\hline \multirow[b]{2}{*}{ Month } & \multicolumn{2}{|c|}{$\begin{array}{l}\text { Long-tern mean } \\
\text { monthly discharge of } \\
\text { Bear Creek, in cubic } \\
\text { feet per second } \\
\end{array}$} & \multirow{2}{*}{$\begin{array}{l}\text { Percent } \\
\text { difference }\end{array}$} \\
\hline & Estimated ${ }^{1}$ & Actual & \\
\hline October & 28 & 28 & 0 \\
\hline November & 24 & 24 & 0 \\
\hline December & 19 & 22 & -14 \\
\hline January & 12 & 14 & -14 \\
\hline February & 16 & 12 & +33 \\
\hline March & 17 & 17 & 0 \\
\hline April & 73 & 77 & -5 \\
\hline May & 218 & 251 & -13 \\
\hline June & 278 & 273 & +2 \\
\hline July & 121 & 93 & +30 \\
\hline August & 22 & 14 & +57 \\
\hline September & 16 & 10 & +60 \\
\hline
\end{tabular}

1 Estimated using monthly flow distribution of Kootenai Creek near Victor.

Table 19. Estimated long-term mean monthly discharges and errors for Swan River near Condon (site 84)

\begin{tabular}{|c|c|c|c|}
\hline \multirow[b]{2}{*}{ Month } & \multicolumn{2}{|c|}{$\begin{array}{l}\text { Long-term mean } \\
\text { monthly discharge of } \\
\text { Swan River, in cubic } \\
\text { feet per second }\end{array}$} & \multirow{2}{*}{$\begin{array}{l}\text { Percent } \\
\text { difference }\end{array}$} \\
\hline & Estimated ${ }^{1}$ & Actual & \\
\hline October & 75 & 60 & +25 \\
\hline November & 78 & 61 & +28 \\
\hline December & 75 & 57 & +32 \\
\hline January & 68 & 48 & +42 \\
\hline February & 71 & 49 & +45 \\
\hline March & 81 & 52 & +56 \\
\hline April & 195 & 191 & +2 \\
\hline May & 388 & 448 & -13 \\
\hline June & 467 & 523 & -11 \\
\hline July & 235 & 274 & -14 \\
\hline August & 98 & 96 & +2 \\
\hline September & 76 & 61 & +25 \\
\hline
\end{tabular}


Table 20. Estimating equations for flow-duration curve streamflows in Region 1

\begin{tabular}{|c|c|c|}
\hline $\begin{array}{l}\text { Discharge, } \\
\text { in cublc feet } \\
\text { per second, } \\
\text { for indicated } \\
\text { exceedance } \\
\text { percentage }\end{array}$ & Equation & $\begin{array}{c}\text { Coefficient } \\
\text { of } \\
\text { determination } \\
\left(r^{2}\right)\end{array}$ \\
\hline$Q_{10}=$ & $2.866 Q_{A} 0.995$ & 0.981 \\
\hline$Q_{20}=$ & $1.606 Q_{A} 0.959$ & .962 \\
\hline$Q_{30}=$ & $0.961 Q_{A} 0.941$ & .945 \\
\hline$Q_{40}=$ & $0.603 Q_{A} 0.957$ & .937 \\
\hline $8_{50}=$ & $0.400 Q_{A} 0.985$ & .932 \\
\hline$Q_{60}=$ & $0.279 Q_{A} 1.015$ & .922 \\
\hline $8_{70}=$ & $0.197 Q_{A} 1.049$ & .905 \\
\hline$Q_{80}=$ & $0.143 Q_{A} 1.084$ & .875 \\
\hline$Q_{90}=$ & $0.119 Q_{A} 1.082$ & .849 \\
\hline
\end{tabular}

Table 21. Estimating equations for flow-duration curve streamflows in Region 2

\begin{tabular}{|c|c|c|}
\hline $\begin{array}{l}\text { Discharge, } \\
\text { in cubic feet } \\
\text { per second, } \\
\text { for indicated } \\
\text { exceedance } \\
\text { percentage }\end{array}$ & Equation & $\begin{array}{l}\text { Coefficient } \\
\text { of } \\
\text { determination } \\
\left(r^{2}\right)\end{array}$ \\
\hline$Q_{10}=$ & $1.390 o_{A} 1.170$ & 0.971 \\
\hline$Q_{20}=$ & $0.738 Q_{A} 1.156$ & .952 \\
\hline$Q_{30}=$ & $0.598 Q_{A} 1.057$ & .922 \\
\hline$Q_{40}=$ & $0.446 g_{A} 1.013$ & .918 \\
\hline$Q_{50}=$ & $0.334 Q_{A} 1.000$ & .909 \\
\hline$Q_{60}=$ & $0.242 Q_{A} 1.008$ & .916 \\
\hline $8_{70}=$ & $0.185 Q_{A} 1.008$ & .909 \\
\hline$Q_{80}=$ & $0.147 Q_{A} 1.005$ & .903 \\
\hline$Q_{90}=$ & $0.118 Q_{A} 0.997$ & .889 \\
\hline
\end{tabular}


Table 22. Average prediction error for regression equations

\begin{tabular}{|c|c|c|c|c|c|c|c|c|c|c|}
\hline \multirow[b]{2}{*}{ Reg1on } & \multicolumn{10}{|c|}{$\begin{array}{l}\text { Average error of prediction, in percent, } \\
\text { for flow charecteristic indicated }\end{array}$} \\
\hline & $Q_{A}$ & $Q_{10}$ & $Q_{20}$ & $0_{30}$ & $0_{40}$ & $Q_{50}$ & 060 & 070 & $Q_{80}$ & $0_{90}$ \\
\hline 1 & -16 & +2 & -8 & -9 & -6 & -6 & -16 & -19 & -29 & -38 \\
\hline 2 & -23 & -15 & -2 & +2 & +5 & +5 & +8 & +12 & +15 & +18 \\
\hline
\end{tabular}

Table 23. Average prediction error for regression equations determined from gaged data only

\begin{tabular}{|c|c|c|c|c|c|c|c|c|c|c|}
\hline \multirow[b]{2}{*}{ Reg1on } & \multicolumn{10}{|c|}{$\begin{array}{l}\text { Average error of prediction, in percent, } \\
\text { for flow characteristic indicated }\end{array}$} \\
\hline & $Q_{A}$ & $0_{10}$ & $Q_{20}$ & $Q_{30}$ & $Q_{40}$ & 050 & $0_{60}$ & $0_{70}$ & $Q_{80}$ & $Q_{90}$ \\
\hline 2 & -6 & -6 & -11 & -11 & -6 & -3 & -5 & -9 & -15 & -18 \\
\hline $2^{3}$ & -4 & +2 & +5 & -1 & -1 & -4 & -7 & -4 & -2 & -8 \\
\hline
\end{tabular}

I Not en average for Region 2; these are the results for one site.

Table 24. Range of independent variables

\begin{tabular}{ccc}
\hline Drainage area & $\begin{array}{c}\text { Mean annual } \\
\text { Region }\end{array}$ & $\begin{array}{c}(P) \\
(\text { square miles) } \\
(\text { inches })\end{array}$ \\
1 & $5.29-766$ & $15-72$ \\
2 & $2.88-71.3$ & $47-72$ \\
\hline
\end{tabular}




\section{METRIC CONVERSION FACTORS}

The following factors can be used to convert inch-pound units in this report to the International System of Units (SI).

\begin{tabular}{lcll}
\hline Multiple inch-pound unit & By & To obtain SI unit \\
\hline $\mathrm{ft}^{3} / \mathrm{s}$ (cubic foot per second) & 0.02832 & cubic meter per second \\
$\mathrm{ft}$ (foot) & 0.3048 & meter \\
in. (inch) & 25.40 & millimeter \\
$\mathrm{mi}$ (mile) & 1.609 & kilometer \\
$\mathrm{mi}^{2}$ (square mile) & 2.590 & square kilometer \\
\hline
\end{tabular}

National Geodetic Vertical Datum of 1929 (NGVD of 1929): A geodetic datum derived from a general adjustment of the firstorder levels nets of both the United States and Canada, formerly called mean sea level. NGVD of 1959 is referred to as sea level in this report. 